Portland State University

PDXScholar

\title{
Late Pleistocene and recent archaeology and geomorphology of the south shore of Harney Lake, Oregon
}

Keith Donald Gehr

Portland State University

Follow this and additional works at: https://pdxscholar.library.pdx.edu/open_access_etds

Part of the Archaeological Anthropology Commons Let us know how access to this document benefits you.

Recommended Citation

Gehr, Keith Donald, "Late Pleistocene and recent archaeology and geomorphology of the south shore of Harney Lake, Oregon" (1980). Dissertations and Theses. Paper 858.

https://doi.org/10.15760/etd.858

This Thesis is brought to you for free and open access. It has been accepted for inclusion in Dissertations and Theses by an authorized administrator of PDXScholar. Please contact us if we can make this document more accessible: pdxscholar@pdx.edu. 
AN ABSTRACT OF THE THESIS OF Keith Donald Gehr for the Master of Arts in Anthropology presented March 7, 1980.

Title: Late Pleistocene and Recent Archaeology and Geomorphology of the South Shore of Harney Lake, Oregon.

APPROVED BY MEMBERS OF THE THESIS COMMITTEE:

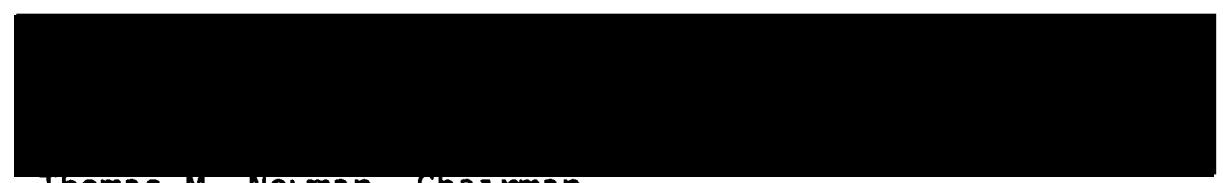

Thomas M. Newman, Chatrman
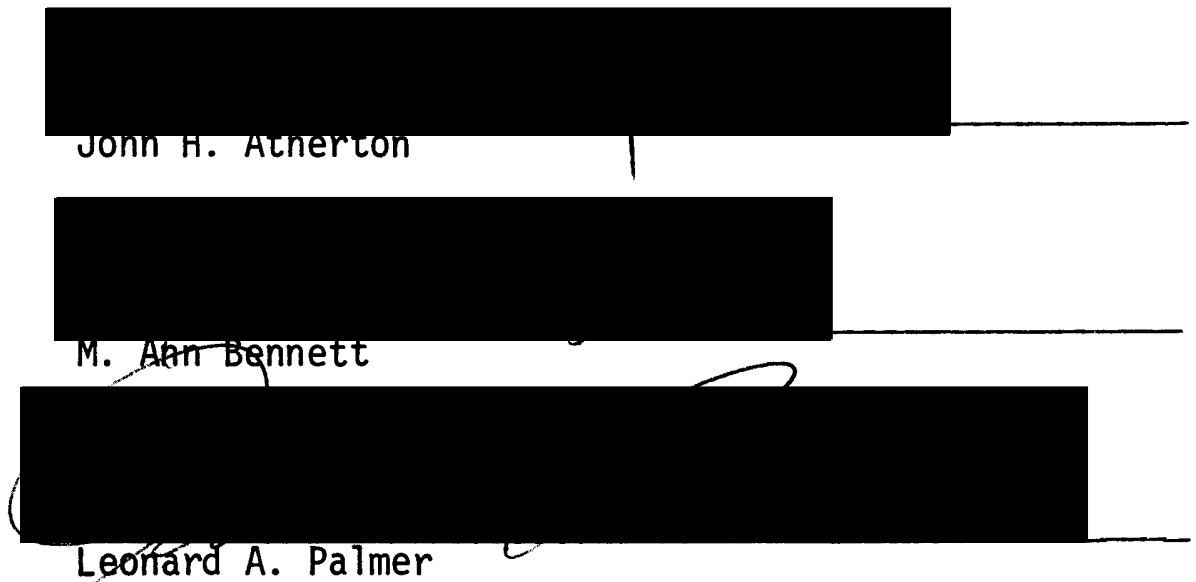

The present study was a response to the discovery of two artifacts found in a ditch wall near Harney Lake, Oregon. These were lying on a buried lake floor that appeared to be of late Pleistocene or early Recent age. Other sediments exposed in the ditch seemed to relate to at least some of the phases of the pluvial lake sequence in the Harney Basin.

Three problems were considered: (1) the geomorphology and 
dating of the pluvial lake stillstands, (2) whether the original artifacts were part of a larger early site, and (3) whether there was any relationship between archaeological sites and geomorphic features in the area.

These problems were approached in the field by stratigraphic mapping of exposed sediments and by an archaeological survey of a defined study area. Test excavations were made adjacent to the location of the original artifact discovery to search for other cultural material.

Beachline records of four stillstands of Pluvial Lake Malheur are preserved in the exposed sediments. The youngest beachline is undated. Three others were ${ }^{14} \mathrm{C}$ dated from associated fossil molluscs at $32,000,9620$ and 8680 B.P. At least in the case of the 8680 B.P. lake, the Harney Basin was filled to overflowing and was a part of the Columbia River system. The Voltage basalt flow, which dammed the outlet of the Basin in Malheur Gap, was in place by 32,000 years ago. There is no evidence for a diversion of the Basin outlet to Crane Gap following this event.

Molluscan fossils and diatoms were used, along with soil texture analyses, to help identify and differentiate sedementary deposits and to draw environmental inferences.

Artifacts were found both on and beneath buried beach deposits of the 8680 B.P. lake. Four of the five sites in the study area were either on wave-cut terraces or other lakeshore features associated with this lake. Diagnostic artifacts are Lind Coulee points, crescents, basally ground leaf-shaped points, and what are apparently true blades. The sites seem to have been located to take advantage of shallow water 
littoral zone resources.

Fish may have been an important dietary item of the early Harney Basin dwellers. Large salmonid vertebrae from fish in the $10 \mathrm{~kg}$ weight class are found on the playa.

By using the relationship between landforms and elevations it may be possible to predict the general age class of other sites on the margin of the playas. 


\title{
LATE PLEISTOCENE AND RECENT ARCHAEOLOGY AND GEOMORPHOLOGY \\ OF THE SOUTH SHORE OF HARNEY LAKE, OREGON
}

\author{
by
}

KEITH DONALD GEHR

A thesis submitted in partial fulfillment of the requirements for the degree of

\author{
MASTER OF ARTS \\ in \\ ANTHROPOLOGY
}

Portland State University

1980

(C) Keith D. Gehr 1980 


\section{TO THE OFFICE OF GRADUATE STUDIES AND RESEARCH:}

The members of the committee approve the thesis of Keith Donald Gehr presented March 7, 1980.

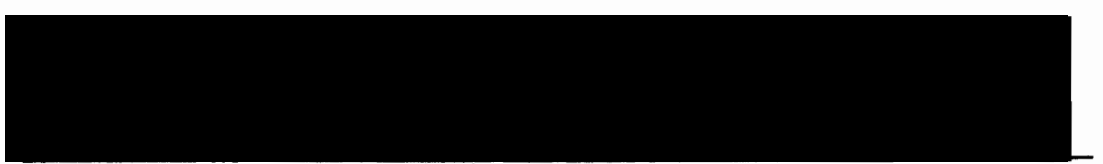

Thomas M. Newman, Chairman
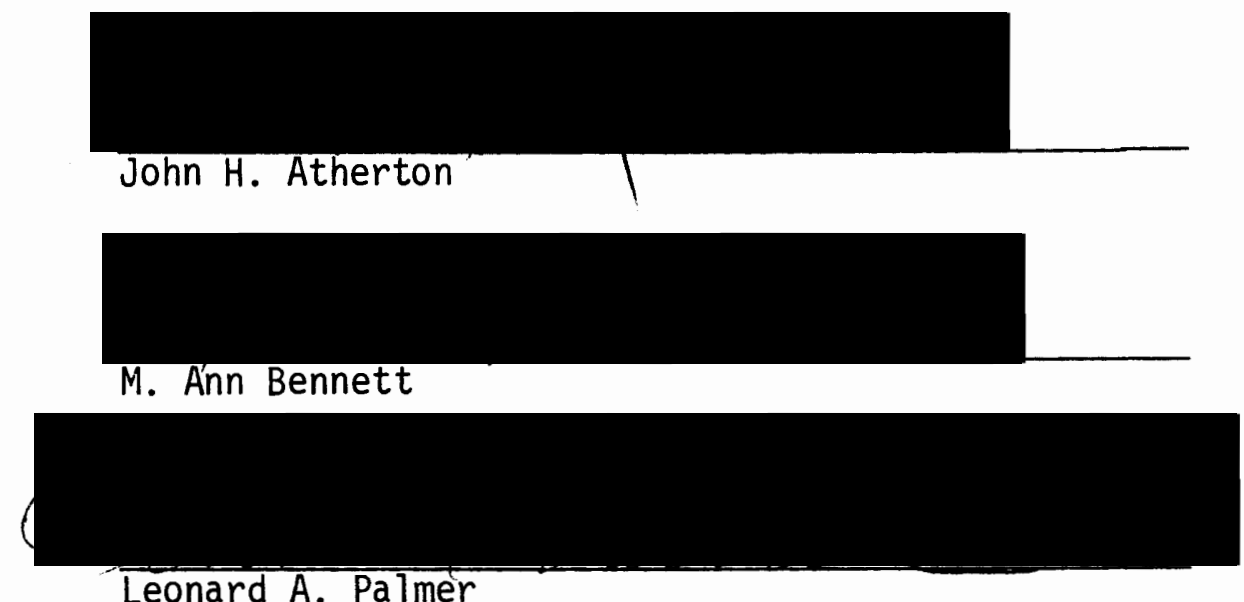

APPROVED:

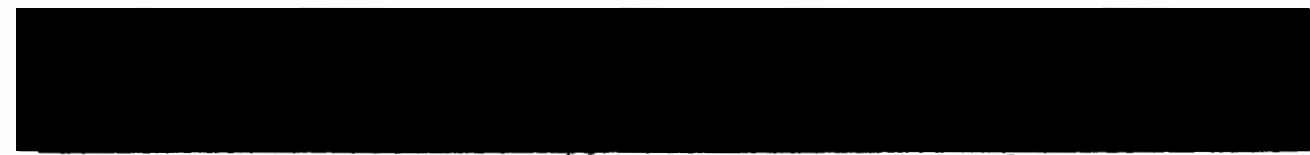

Daniel J.Scheans, Head, Départment of Anthropology

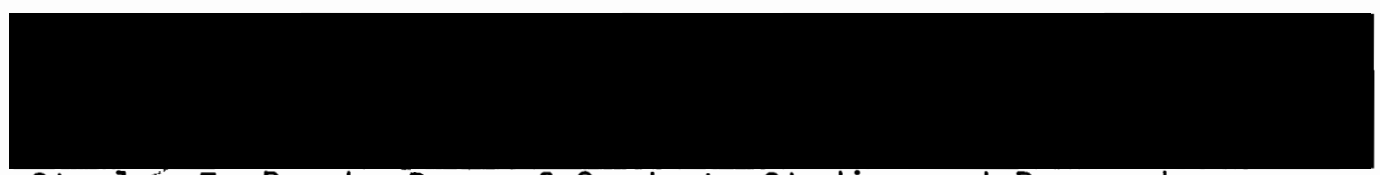

StanFey E. Rauch, Dean of Graduate Studies and Research 


\section{ACKNOWLEDGEMENTS}

Many people have made critical contributions to this project and a mere listing of their names seems to be a shallow recognition of their generous help. Without them, neither the field work or this report could have ever been completed. I am deeply grateful for their assistance.

At the head of the list, I want to thank the members of my committee--Drs. Thomas Newman, Ann Bennett, John Atherton and Leonard Palmer. Dr. Palmer, in particular, patiently steered me through much of the unfamiliar ground of geomorphic interpretation.

Dr. Donald Grayson, University of Washington, gave extremely helpful suggestions on organization and editing. He led me away from a number of primrose paths of style and interpretation.

Several friends gave valuable vacation time to help with field work. Jim and Michelle Bieber, Toni Graham, Susan Wiebe, Dr. John Hammond and Susan Nielsen were mainly rewarded with sunburn, blisters, and mosquito bites.

Dr. Dwight Taylor, Tiburon Center for Environmental Studies, identified the molluscs and provided information on their preferred habitats. Malacologists with his great skill are rare people and I am honored that he gave his time and knowledge.

I owe special thanks to Dr. Stephen Robinson and to the United States Geological Survey who ran all of the radio carbon dates. In a project with a zero budget this help was absolutely critical and it is very deeply appreciated. 
Dr. Kevin Howe, Oregon State University, identified and helped interpret the fossil fish remains. This is another skill that is not easy to find. I appreciate his contribution.

Mr. James Sweet, Portland State University, spent many hours identifying diatoms and trying to teach me what they meant. He never showed a hint of exasperation as I continued to heap samples on his desk.

I thank Weyerhaeuser Company for the use of typing, copying, microscopy and other laboratory facilities. A number of the Weyerhaeuser research staff made individual contributions. Dr. Eugene Steinbrenner of the Soil Laboratory ran all of the texture analyses. Charles Worley did the analysis of the salt crust from Harney Lake playa. Anne Budworth spent seemingly endless weekend hours typing the many versions of the manuscript. Michael Wotton proofread the manuscript and suggested extensive stylistic polishing. Robert Herrmann gave much useful advice on the fish and molluscan remains. Dale Quackenbush did the macrophotography of the fossil molluscs.

Finally, so much credit goes to my wife Betty for advice, help and encouragement from beginning to end that I cannot even begin to express my gratitude to her. 
TABLE OF CONTENTS

PAGE

ACKNOWLEDGEMENTS . . . . . . . . . . . . . . . . .

\section{SECTION}

I THE HARNEY BASIN - BACKGROUND AND OVERVIEW . . . . . 1

A. Geographic Description ......... 1

B. Geology.............. 5

C. Present Climate........... 15

D. Past Climate ............... 19

E. Hydrology .............. 29

F. Human Occupation - Archaeology ...... 36

II THE SOUTH HARNEY LAKE PROJECT . . . . . . . . . . 43

A. Introduction - The Problem and Approach . . . 43

B. Field Work ............. 49

1. Geomorphology .......... . 49

2. Archaeology........... 50

II I ANALYSIS AND RESULTS . . . . . . . . . . . 54

A. Geomorphology - Abandoned Shorelines and Their Chronology .......... . . 54

B. Archaeology ............. 83

C. Faunal Analysis............. 114

1. Mammals ............ 115 
2. Fish................ 116

3. Diatoms ............... 120

4. Molluscs.............. . . 125

IV SUMMARY AND CONCLUSIONS . . . . . . . . . . . . . . 145

BIBLIOGRAPHY . . . . . . . . . . . . . . . . . . . 150

APPENDIX . . . . . . . . . . . . . . . . . . . . 165

Survey Benchmark Locations . . . . . . . . . . . 165

Radiocarbon Dating Summary . . . . . . . . . . 166 


\section{LIST OF TABLES}

TABLE

PAGE

I Annual Rainfall at Four Stations in the Malheur

National Wildlife Refuge: 1937 - 1977 . . . . 16, $16 a$

II Severe Rainfall Expectancy for the Harney Basin . . . 18

II Analysis of Salt Crust from Harney Lake Playa . . . 33

IV Texture Analysis of North Ditch Soils:

Location 16N..................... 63

V Texture Analysis of Soil Samples: Square 4E-4S ... 89

VI Living Fresh Water Mollusc Species in Malheur

National Wildlife Refuge .......... . . 128

VII Fossil Snail Species from Study Area . . . . . . 129, 130

VIII Elevations and Dates of Pluvial Lake Malheur

Shorelines.............. . . 146

IX Summary of ${ }^{14} \mathrm{C}$ Samples ............ . . 170 


\section{LIST OF FIGURES}

FIGURE

PAGE

1. The Harney Basin, Oregon ............. 2

2. The American Great Basin.............. 4

3. Spillway Gaps of the Harney Basin ........... . 6

4. Estimates of Conditions to Maintain Pluvial Lake Malheur

at Overflow Level ............ . . 23

5. Estimated \% of Average Runoff of Truckee River: 1839-40

to $1938-39 \ldots \ldots 27$

6. Surface Area vs. Water Capacity of Malheur and Harney Lakes 32

7. General Location of Study Area, Harney County, Oregon . . . 45

8. Map of Pleistocene Jackass Bay of Pluvial Lake Malheur . . 47

9. Bearings of Survey Line of Stratigraphic Sections . . . . 158

10. Stratigraphic Section - North End of Site: 50X Vertical

Exaggeration, Locations $18 \mathrm{~N}$ to $13 \mathrm{~S}$. . . . . . 159

11. Stratigraphic Section - South End of Site: 50X Vertical

Exaggeration, Locations $11 \mathrm{~S}$ to $42 \mathrm{~S}$....... 160

12. Stratigraphic Section - Youngest Beach Ridge: 10X Vertical

Exaggeration, Locations $20 \mathrm{~N}$ to $16 \mathrm{~N} \ldots . . . . .161$

13. Stratigraphic Section - 32,000 B.P. Pleistocene Beach

Ridge: 10X Vertical Exaggeration, Locations 2N to 4S 162

14. Stratigraphic Section - 9620 B.P. Beach Ridge: 10X Vertical

Exaggeration, Locations 75 to 145 . . . . . . 163 
15. Stratigraphic Section - 8680 B.P. Beach Ridge: 10X Verti-

cal Exaggeration, Locations 175 to 30 S ...... 164

16. Test Excavation Locations . . . . . . . . . . . . 51

17. Archaeologicat Site Locations in Study Area . . . . . . . 53

18. General View of Drainage Ditch ............ 55

19. Cut Through Youngest Beach Ridge ... . . . . . . . 57

20. Shingled Beach Ridge Series on South Shore of Harney Lake . . 58

21. Sediments Exposed Near North End of Ditch . . . . . . . . 62

22. Buried Beach Ridge Associated with 32,000 B.P. Lake . . . . . 64

23. Foreset Beds Terminating 32,000 B.P. Beach Ridge ..... 66

24. Transverse Erosion Channels in Jackass Soil . . . . . . 69

25. Older Lake Floors Buried Under 32,000 B.P. Beach Ridge . . . 72

26. Portion of Beach Ridge Series Marking Limit of 9620 B.P.

Lake ................ . . 73

27. Broad Wave-Cut Terrace Along South Shore of Harney Lake . . 78

28. Wave-Cut Terrace on Butte Adjacent to Malheur National

Wildl ife Refuge Headquarters ......... . 79

29. Abandoned Channel of Harney Basin Outlet Stream Cut into

Voltage Lava at East End of Malheur Gap . . . . . . 81

30. Vertical Aerial Photograph of Study Area Showing Site

Locations and Geomorphic Features ... . . . 84, 85

31. Ditch Wall Showing Site of Original Artifact Discovery . . 87

32. Rock Retained on Screens at Various Excavation Levels . . . 90

33. Ditch Wall Showing Obsidian Bipoint In Situ . . . . . . 92

34. Discovery Site of Obsidian Blade Under 8680 B.P. Lake Gravel 93 
35. Obsidian Blade Shown In Situ Under 8680 B.P. Beach Ridge . 94 36. Trough in Gravels in Ditch Wall Opposite Original Artifact Find Location . . . . . . . . . . . 96

37. Humboldt Point From Ditch Wall at Location 75 . . . . . 98

38. Obsidian Bipoint from Ditch Wall at Location 195 . . . . 99

39. Blade Fragment from Ditch Wall at Location $20.4 \mathrm{~S}$. . . 100

40. Crescents from Site $35 \mathrm{HA} 341$............ 104

41. Artifacts from Site $35 \mathrm{HA} 341 . . . . . . . . . .105$

42. Graving Tool and Crescentic Scraper from Site 35HA341 . . 106

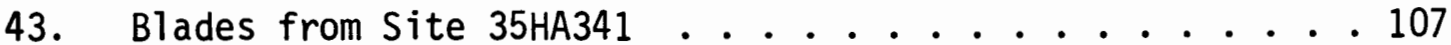

44. Lind Coulee Point from Site $35 \mathrm{HA} 343$......... . 109

45. Chert Blade and Lind Coulee Point from Site $35 \mathrm{HA} 344$. . . 111

46. Salmonid Vertebrae from Harney Lake Playa . . . . . . . 118

47. Fontelicella hendersoni Snail . . . . . . . . 133

48. Vorticifex effusus Snail . . . . . . . . . 134

49. Hel isoma newberryi Snail . . . . . . . . . . 135

50. Lymnea, palustris group Snail . . . . . . . . . 136

51. Planorbella subcrenata Snail . . . . . . . . 137

52. Physa gyrina Snail .............. 138

53. Valvata humeral is Snail ............ 139

54. Gyralus parvus Snail . . . . . . . . . . . 140

55. Ferrissia rivularis Limpet ............ . 141

56. Pisidium ultramontanum Freshwater Clam . . . . . . . 142

57. Sphaerium striatinum Freshwater Clam . . . . . . . 143 


\section{THE HARNEY BASIN - BACKGROUND AND OVERVIEW}

\section{A. Geographic Description}

The Harney Basin is centered about $119^{\circ} \mathrm{W}$ longitude and $43^{\circ} 30^{\prime} \mathrm{N}$ latitude, primarily in Harney County in southeastern Oregon (Fig. 1). It is the largest of the closed basins in the state, covering an area of about $13,730 \mathrm{~km}^{2}\left(5300 \mathrm{mi}^{2}\right)$. This is high, semi-arid country, ranging from a low elevation of $1243 \mathrm{~m}(4078 \mathrm{ft}$ ) above sea level on Harney Lake playa to $2967 \mathrm{~m}(9733 \mathrm{ft}$ ) at the summit of Steens Mountain (Piper, Robinson, and Park, 1939; Dog Mountain, Oregon 1959; Wildhorse Lake, Oregon 1968).

Alluvial plains cover about $2070 \mathrm{~km}^{2}\left(800 \mathrm{mi}^{2}\right)$ of the basin floor. In addition, there are about $325 \mathrm{~km}^{2}\left(125 \mathrm{mi}^{2}\right)$ of playas or semipermanent shallow lake water. These plains lie primarily between elevations of $1250 \mathrm{~m}$ and $1280 \mathrm{~m}(4100 \mathrm{ft}$ to $4200 \mathrm{ft})$ and include most of the agriculturally important land in the basin.

Two major and one smaller playas dominate the low country. These are Malheur, Harney and Silver Lakes. (This latter playa should not be confused with the much larger dry lake of the same name located in the Fort Rock Basin about $115 \mathrm{~km}$ (70 mi) to the west.) Harney and Silver Lakes are normally dry much of the year. Malheur Lake, actually an extensive marsh of greatly variable size, is the only one of these that normally contains water on a year-around basis.

Despite the fact that most of its water is lost by evaporation, Malheur Lake water has a relatively low content of dissolved salts. In high runoff years it overflows into Harney Lake, the ultimate sump for water in the Basin. Apparently this occasional flushing is sufficient to 


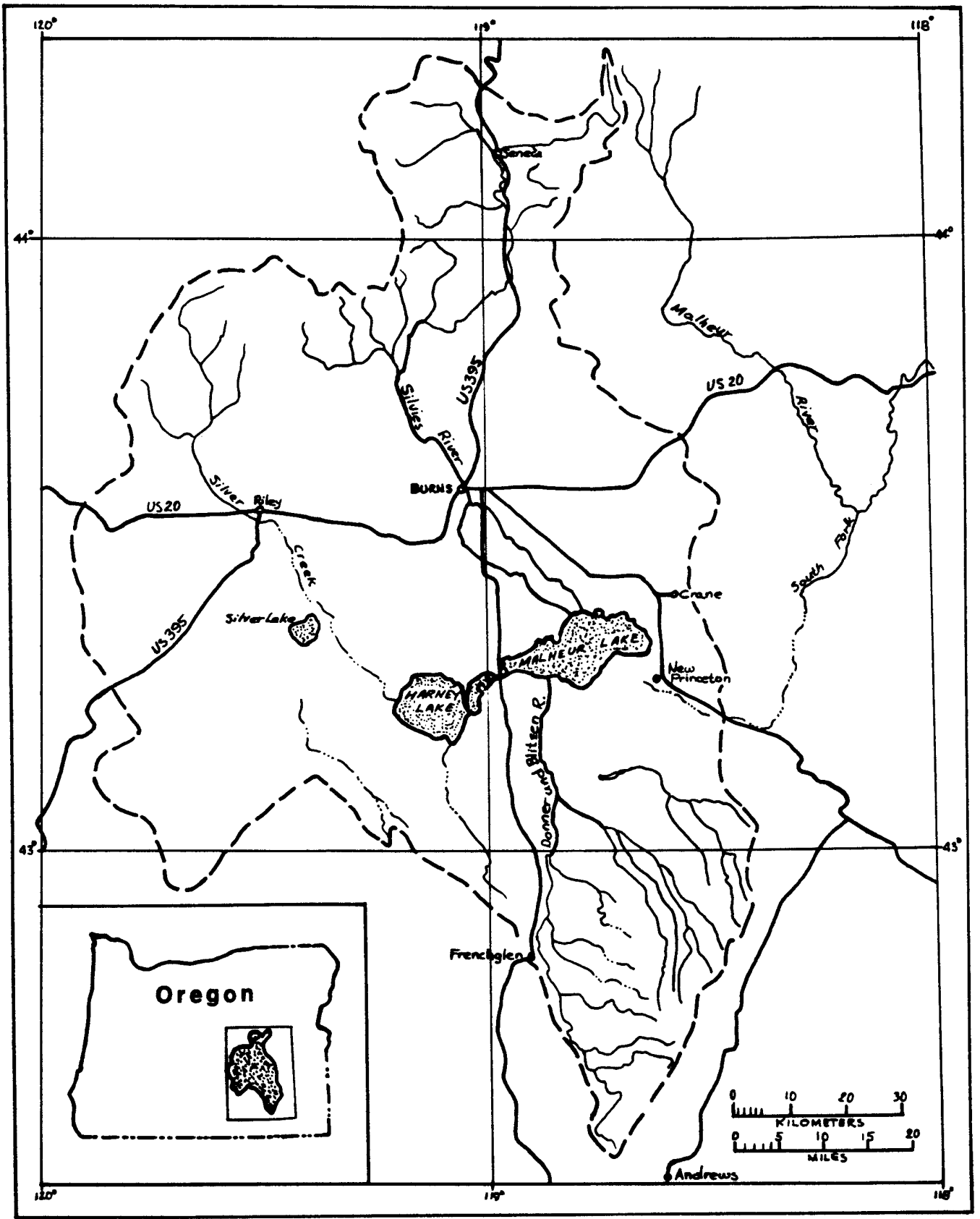

Figure 1. The Harney Basin, Oregon 
keep Malheur Lake fresh. Not so for Harney Lake: when it does contain water the salt content and alkalinity are high. In late summer the playa is normally covered by a crust of glistening white alkali salts.

The Harney Basin and the adjacent Fort Rock Basin to the west represent the extreme northwesterly outliers of the Great Basin, an area of internal drainages within the American basin and range physiographic province. Morrison describes it well:

Despite its name, the Great Basin is not a single large basin. It contains more than 150 desert basins (mostly closed) separated from each other by more than 160 discontinuous, subparallel mountain ranges, trending roughly north-south. Dutton aptly likened the pattern of ranges to that of an 'army of caterpillars marching to Mexico.' The result of high-angle faulting; the ranges commonly are uplifted as horsts (commonly somewhat tilted), and the basins are down-dropped as grabens. (Morrison 1965:265)

It includes much of the State of Nevada and covers major areas in California and Utah and smaller areas in Wyoming, Idaho and Oregon (Fig. 2).

Definitions of the overall extent of the Great Basin tend to vary from writer to writer, depending on whether they are based on physiographic or hydrographic criteria. As one example, the Klamath Lake Basin is often included within the physiographic province but is excluded from the Great Basin on a hydrographic basis (Cressman 1977:20).

These criteria are of more than casual importance to a study of both the physical and archaeological aspects of the Harney Basin. When at its maximum elevation, the Pleistocene lake in the Harney Basin overflowed through Malheur Gap into the South Fork of the Malheur River and thence by the Snake and Columbia Rivers to the Pacific Ocean. This connection with the Columbia River system introduced a wider freshwater faunal assemblage than was found in nearby closed basins. In particular it is quite 


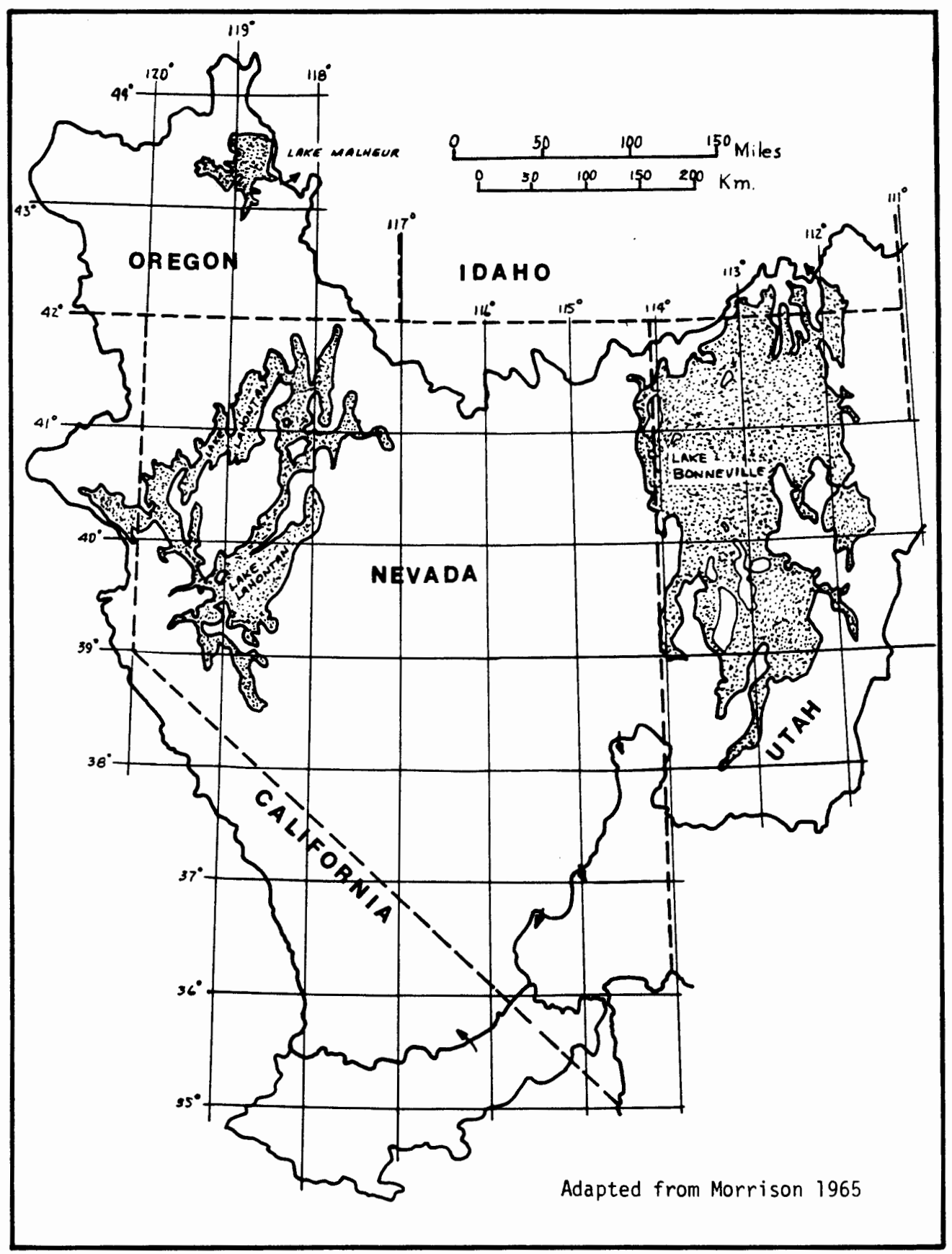

Figure 2. The American Great Basin 
probable that large anadromous fish offered an important seasonal food source to early inhabitants. The presence of such fish is shown by fairly abundant salmonid fossils found in various locations on the alluvial plain and even on the surface of Harney Lake playa.

Snyder (1908) showed conclusively that the fish in the bas in have "a close faunological relation" with the Columbia system. He failed to find evidence "that the fishes which are isolated in the Malheur Basin have visibly differentiaţed from their congeners in the Columbia." Hubbs and Miller (1948:75), on the basis of a more extensive study were able to detect enough distinctions to recognize four or five endemic subspecies in this isolated system. From this they concluded "This moderate degree of speciation suggests a somewhat prolonged isolation, perhaps from late Pleistocene time."

At some point in time after $8700 \mathrm{BP}$, the water supply to Pluvial Lake Malheur(1) decreased to the point that overflow through Malheur gap no longer occurred. At that time the basin became hydrographically isolated.

\section{B. Geology}

At various times in the geologic past the Harney Basin has drained into the Columbia River system through one of two outlet channels (Figure 3 ). The first, now known as Crane Gap, is a roughly east-west breach

(1) Throughout this paper I will follow the suggestion of Hubbs and Miller (1948) in naming the ancestral lake in the Harney Basin. While they equate Pluvial Lake Malheur and Lake Malheur in meaning, I will use the first form to avoid confusion with Malheur Lake, the existing body of water and marshland. Snyder, Hardman, and Zdenek (1964) have followed Hubbs and Miller in terminology in their recent geological map of the lakes and drainages in the Great Basin. 
Figure 3. Spillway gaps of the Harney Basin

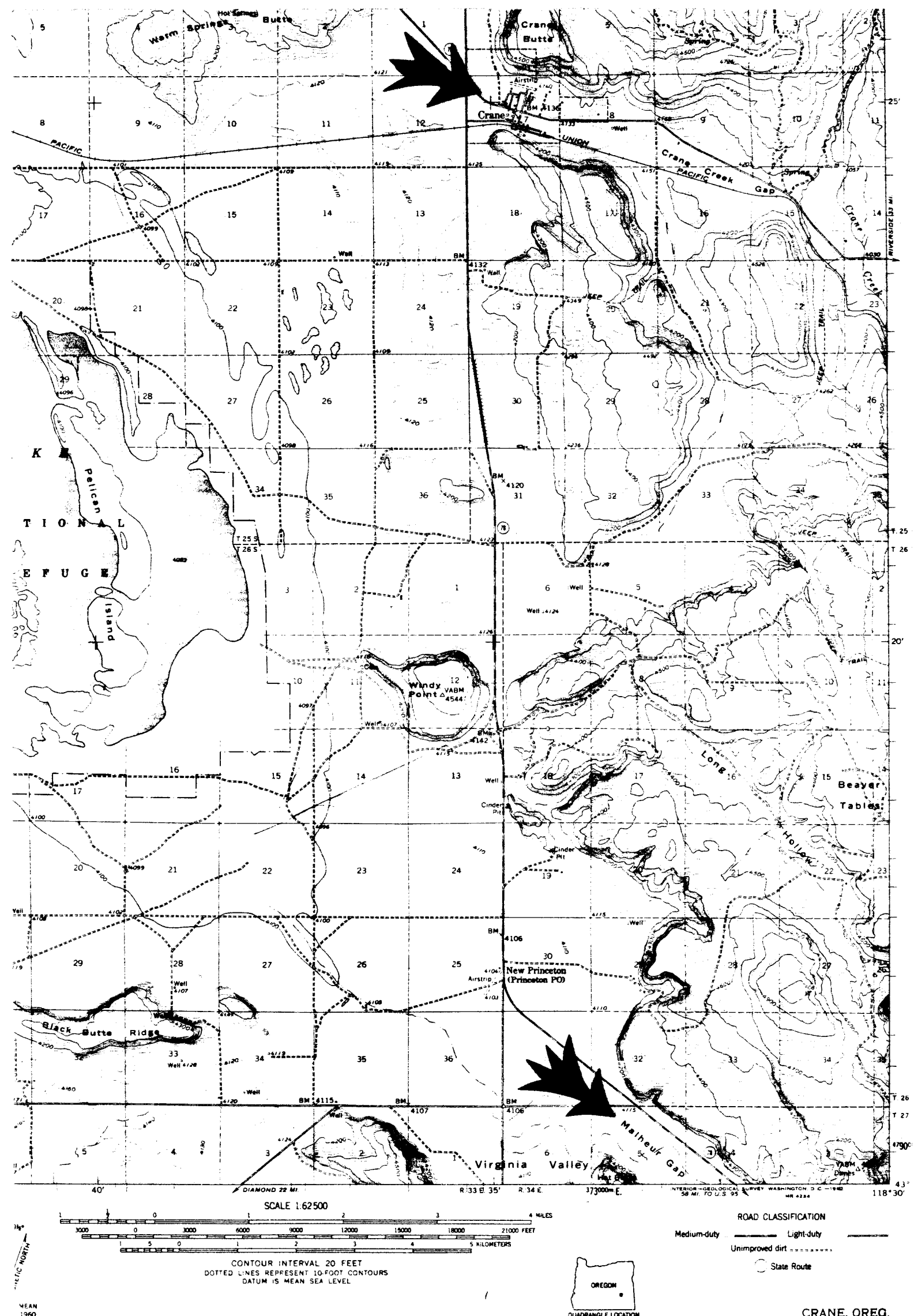


through a series of hills formed by generally north-south faulting. The present divide in this gap between the Harney Basin on the west and Crane Creek drainage to the east, is about $5 \mathrm{~km}(3 \mathrm{mi})$ east of the present village of Crane at an elevation slightly below $1268 \mathrm{~m}$ (4160 ft) (Crane, Oregon 1960). Crane Creek is a tributary of the South Fork of the Malheur River and thus of the Columbia River system. The other Basin outlet, Malheur Gap, lies roughly $18 \mathrm{~km}$ (11 mi) south of Crane Gap. It is an east-west tending graben through hills formed by generally east-west faulting. The present divide between Harney Basin drainage and South Fork of the Malheur River is at an elevation of about $1254 \mathrm{~m}(4114 \mathrm{ft})$, roughly $14 \mathrm{~km}(8.5 \mathrm{mi})$ east of the tiny settlement of New Princeton (Piper et al. 1939; Green et al. 1972; Crane, Oregon 1960; Adobe Flat, Oregon 1967; Circle Bar, Oregon 1972; Sand Gap, Oregon 1977).

At some point in the Pleistocene the eastern end of Malheur Gap was dammed by an extensive lava flow. At that time, this gap apparently had a floor about $92 \mathrm{~m}(300 \mathrm{ft}$ ) lower than it presently does and formed the outlet of the Harney Basin (Piper et al 1939:2). One effect of the dam was to create a large lake within the Basin. A secondary effect was to begin a period of rapid alluviation within the Basin since sediments could no longer efficiently be carried out.

The present study is in large part directed to the examination and interpretation of lake floors, strandlines and terraces in the Harney Basin formed after the time when the lava flow had dammed Malheur Gap.

It is useful now to look at a history of geologic study in the Harney Basin and to briefly outline the geologic forces that have brought it to its present form. 
In the Harney Basin the first field geologist followed right on the heels of the first cattle. Israel C. Russell, of the United States Geological Survey, traversed the region in 1882 in connection with a study of Quaternary lakes (Russell 1884). Again, in 1902 he made a second trip to study the general geology and water resources (Russell 1903a and 1903b). One year later he made a third trip through the region in which he expanded his observations, especially on the outflow channels from the Basin (Russell 1905).

Russell was a competent geologist and his work on the Lahontan Basin is still frequently cited. Considering the short time he was in the Basin and the difficulty of field travel his work there was also remarkably good. Unfortunately, he made some misstatements which have been perpetuated through the literature to the present time, of which the following is an example.

The inner slopes of the valley in which Malheur and Harney lakes are situated are not scored with old beach lines or terraces, as is the case in so many of the similar valleys of the Great Basin. This is consistent with the low elevation of the old river channel leading eastward from the valley to the headwaters of Malheur River. As already stated, the present hydrographic basin of Malheur and Harney lakes was formerly a part of the Malheur River drainage system and was cut off by a lava flow which entered the channel of the former and greater Malheur River. On account of the small precipitation and active evaporation in the region above the broad lava dam, the water in the basin thus cut off has never been able to rise sufficiently to cross the obstruction which retains it. The evidence thus furnished tending to show that Malheur and Harney lakes are not remnants of a former large water body, is also in harmony with their chemical composition. Their present degree of salinity indicates but a comparatively short period of time since the dam which retains them was formed. The lava sheet referred to is, however, covered with a thin soil, and supports a rank growth of sagebrush, indicating that it is much older than the very recent lava flows about the Diamond, Bowden, and Jordan craters, to be described later. (Russeli 1903b:32; emphasis mine.) 
After his next visit Russell modified his views of the lava dam slightly,

The blackness of the lava and the scarcity of evidence of disintegration or decay, as well as the absence of vegetation other than sagebrush and the plants usually associated with it, give an impression of recency, but the weak stream that flows down the valley has cut a channel from 50 to 75 feet deep near where it leaves the lava. The scarcity of soil and of vegetation is due to the aridity of the climate, and is not in itself an index of youthfulness in the soil beneath, while the considerable amount of work accomplished by the weak and now ephemeral stream is suggestive of centuries of slow erosion. The lava stream can not, therefore, be considered as young in years, although, with the exception of the Jordan and Diamond volcanoes and lava flows, it is the latest considerable addition to the surface rocks that has been made in eastern Oregon. (Russell 1905:37)

Apparently there was considerable water in Harney Lake in the summer of 1902 when Russell made his second trip. A statement he made is somewhat amusing to one whose immediate mental picture of Harney Lake is a hot, shimmering white playa with huge dust devils dancing across it,

Judging from the appearance of the lake when seen from adjacent hills, and from the ineffectual attempts to sound it made by fishermen, it is to be expected that a depth varying from 50 to 100 feet throughout a large portion of its central and southwest portions will be discovered when an accurate survey is made. (Russell 1903b:29)

The first really comprehensive study of the geology and water resources of the Basin was made by another Geological Survey scientist, Gerald A. Waring (1909). This publication also covered the physical and economic geography of the basin in detail. Waring's study was in good depth and was so thoroughly professional that little in it needs to be modified today except for those economic and demographic changes effected over the past 70 years. 
Waring did not speculate on the lava flow that dammed Malheur Gap other than to recognize that it was geologically recent. He did comment specifically on the absence of Pleistocene shoreline features, however.

The lakes of southeastern Oregon are very good examples of the dependence of such bodies on the climate for their existence. During the Pleistocene epoch the basins that were produced by earlier deformation of the lavas were occupied by water bodies many of which have left evidence of their extent in slight terraces or water lines along the valley sides... In the largest basin, that of Harney and Malheur lakes, no such record is noticeable, probably because of the shallowness of the ancient lake; but the character of the deposits throughout its extent shows unmistakably that they are of lacustrine origin. (Waring 1909:29)

Waring's study was really of pioneering nature and it deserves more attention than it can be given in this brief historical overview. It served as the authority for the Basin until the publication of a major Geological Survey study three decades later by Piper, Robinson, and Park (1939). Even today this is the most thorough and complete source on the geology and hydrology of the basin. Later students have added to it here and there but cannot approach it in general usefuiness. Throughout the rest of this study I will draw liberally from their work.

Piper et al (1939), give a most compact overview of the geology of the basin. I am indebted to them for a long quotation.

The history of the Harney Basin seems to include the following stages: (a) Approximately in late Miocene time the site of the Basin was a district of moderate or strong relief whose rocks included (a) metamorphosed sedimentary strata and crystalline plutonic rocks of several kinds, in part of Lower Jurassic age, which had been faulted and compressed; and (b) siliceous extrusives of Miocene (?) age, which had been faulted and loosely crumpled. (2) In Miocene time the Steens basalt was extruded in a series of thin but extensive sheets that buried the older rocks along the eastern margin of the basin with the exception of a few scattered peaks. North of Burns the whole series wedged out by overlap against the crystalline rocks. (3) The present structural basin was outlined in general form by faulting and by tilting of blocks. At that time certain of the present fault scarps 
were perhaps initiated and the major subdivisions of the present upland were outlined. (4) In Pliocene time the Danforth formation was deposited over most of the area; this formation comprised detrital sediments of lacustrine and alluvial origin, coarse and fine ejactamenta, massive spherulitic rhyolite and perlite, and thin discontinuous sheets of rhyolite and basalt. (5) The major faults of the pre-Danforth epoch were rejuvenated, the major fault scarps of the present land surface were formed or heightened, and, by further block tilting, the central part of the basin was depressed still more with reference to the bordering upland. (6) For a relatively long period the region was subject to erosion, and exterior drainage was established through Crane Gap or Malheur Gap, and possibly through both. (7) In late Pliocene (?) time the Harney formation was deposited throughout the central part of the basin and over an extensive area to the west; this formation comprised basalt scoria and pumice, detrital sediments, and some extensive but relatively thin layers of basalt. (8) Through a long fraction of the Pleistocene epoch erosion was again dominant, so that exterior drainage was once more established through Malheur Gap and perhaps briefly through Crane Gap. By stream planation the upper part of the Harney formation was stripped from the central area; it is inferred that ultimately the central area was reduced to a submature land surface which was adjusted to an outlet about 300 feet below the present alluvial tongue in the Malheur Gap.

(9) Immediately prior to the epoch just described, or during the early part of that epoch, a few of the faults were reopened and some blocks were tilted further, particularly along the eastern margin of the basin near the two gaps; however, the major features of the structure are believed to have remained stable. (10) In late Pleistocene time basalt was extruded from vents west of Hines; also from vents east and south of Voltage. From the latter a relatively extensive lava field spread northward and eastward, entered Malheur Gap, and filled that drain up to the level of the present divide near the Gap School. That lava dam has not been breached to this day. (11) The central basin was filled by lake and playa deposits, by alluvium, and by minor quantities of volcanic ash, peat, and wind-borne sand. It is not unlikely that some of the valley fill was deposited contemporaneously with the basalt. In the final stage of this epoch the central alluvial plain was aggraded to its present altitude and the lower reaches of the stream valleys were drowned by alluvium for several miles upstream from the central plain. (12) At some relatively late time in the epoch of valley filling the late basalt of the Diamond Craters was extruded. (pp 26-29)

$k t \star k t$

It is not unlikely that the lower part of the valley fill was deposited in an extensive and relatively deep lake, for the epoch of filling began when Malheur Gap was dammed by basalt, presumably before the end of the Pleistocene epoch, while rainfall was 
relatively great and while other closed basins in southeastern Oregon were occupied by lakes of considerable depth. If the hypothetical lake ever rose to the crest of the basalt dam $(4,114$ feet above sea level) it would have been only about 50 feet lower than the present land surface at Burns and, on the pre-fill topography, would have extended nearly if not entirely across the present alluvial plain. (p 31)

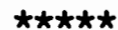

The valley fill has buried a former land surface which comprised two elements--(1) the initial surface of the basalt dam in Malheur Gap and of the northern footslope along the Voltage lava field and (2) an erosion surface whose profiles were adjusted between the predam floor of Malheur Gap and the reaches of the present streams that are incised on the upland. Two useful inferences as to the form of the buried erosion surface can be drawn with fair assurance. First, over a considerable part of the central area, the surface had been eroded on soft tuff and sedimentary beds of the Harney formation and Danforth formation, which resemble the overlying fill in petrographic character. Second, the erosion surface probably had low but distinct relief, because (1) the bordering land forms whose footslopes were buried were youthful and still are youthful; (2) relatively weak salients along its margins, such as Wrights Point and Windy Point, were not smoothed off before the epoch of filling; and (3) the term of erosion was too brief for the outlet of the basin, Malheur Gap, to have been greatly widened, although it is inferred that a considerable volume of detritus was transported through it. On the other hand, surprisingly few outliers of the buried surface now rise above the central plain.

t*tktt

Waring estimates that the valley fill is less than 300 feet thick at most places, deriving his estimate partly from the fragmentary records of five wells on the central plain. These records ... together with the available records of wells that have been drilled through the valley fill subsequently... confirm the estimate made by Waring in 1909. Collectively the records indicate that the valley fill is roughly 100 feet thick within 5 miles of Burns and all along the northeastern margin of the valley plain; that it thickens steadily toward the south and the southeast; and that it is from 200 feet to about 270 feet thick from 2 to 5 miles north of Malheur Lake. South of the lake the valley fill feathers out against the Voltage lava field and is from 20 to 50 feet thick in several wells within half a mile of that field. None of the records indicate the depth to bedrock in the Donner and Blitzen Valley or the Warm Spring Valley. (pp 31, 32) 
Although older than the lava field near Diamond, the Voltage lava field is relatively young in terms of the geologic time scale. It is inferred to have dammed the ancestral Malheur Gap and thereby to have cut off Harney Basin from the drainage area of the Malheur River and to have started the epoch of alluviation that built the extensive central plain. (pp 16, 17)

$k \star t k t$

Two low-level wind gaps pierce the dissected upland along the east side of the basin; these are Crane Gap, with a portal in sec. 7, T. 25 S., R. 34 E., and Malheur Gap .. . which opens from the central alluvial plain 11 miles farther south, in sec. 5, T. 27 S., R. 34 E. Russell has inferred that each of these gaps has been a drainage outlet for the Harney Basin, although no drainage has passed through either within historic time or through Crane Gap in latest geologic time. The writers infer that Malheur Gap was the chief outlet of the basin during the epoch in which so large a volume of the Harney formation was stripped from the central area. The high-level beach ridge [at $1251.2 \mathrm{~m}(4105 \mathrm{ft})$ ] that passes around the east end of Malheur Lake swings within half a mile of the portal of Malheur Gap and is pierced by an illdefined drain that can be traced well into the gap itself. These features suggest that Malheur Lake has spilled eastward through the Malheur Gap during the present geologic epoch, even though it has not done so within historic time. This suggestion, however, is not uncontroverted, for the alluvial floor of the gap rises toward the east and passes over a very low divide in the vicinity of the Gap School. There, 6 miles east of the portal and approximately on the line between Rs. 34 and $35 \mathrm{E}$., the alluvial floor stands 4,114 feet above sea level, or about 25 feet above the floor of the Malheur Lake and 9 feet above the crest of the high-level beach ridge. (p 18)

The eastern half of Malheur Lake is traversed by three abandoned beach ridges, of which the most easterly and westerly are known as Pelican Island and Cole Island, respectively. On the western half of the playa Graves Is land forms a possible correlative of Cole Island. These ridges have stood above water when the playa has been extensively flooded in historic time. Each is breached by several gaps, which drain lagoons.

An older and higher beach ridge is imperfectly preserved at several places about the playas. East of Malheur Lake it extends almost to the portal of Malheur Gap, where its crest is about 4,105 feet above sea level. Farther west it passes through the $W_{2} / 2$ sec. 11, T. 26 S., R. 33 E., skirts the southwestern flanks of Warm Spring Butte and Saddle Butte, and continues about to Lawen. Still farther west the ridge appears to lapse for several miles across the alluvial plain of the Silvies River, but it rises again 
about in sec. 26, T. 25 S., R. 32 E., and extends southwestward into the dunes northeast of Harney Lake. In the latter reach the crests of the principal beach remnants are about 4,100 feet above sea level. A possible correlative of the high-level beach ridge is the highest of four shingled beach terraces that occur south of Harney Lake in sec. 1, T. 28 S., R. $293 / 4$ E. [at $1249.7 \mathrm{~m}(4100$ $\mathrm{ft})$ ]. No higher shore features are known to exist in the central area of the Harney Basin, although most other desert basins in eastern Oregon have prominent shore features at least 100 feet higher than their playas. ( $p$ 14)

These extensive quotations, as well as the briefer quotations from Russell and Waring, help to set the stage for two of the problems dealt with in the present study. Principal of these is the question of the presumed absence of shoreline features in the Harney Bas in with the exceptions of the beach ridges mentioned in the last part of the quotation above. Related to this is the problem of whether, in fact, Malheur Gap ever has served as a connection into the Columbia River system after the volcanic event that dammed it.

Only the briefest mentions will be made here of the more recent geologic studies in the Basin. Walker and Swanson (1967), also of the Geological Survey, made a somewhat finer analysis of the geology and mineral resources in the immediate areas of Harney and Malheur Lakes. Parker and Armstrong (1972), and Parker (1974), report absolute dates for several of the volcanic rock formations in the basin. They conclude that the Harney Formation, which caps many of the buttes in the Basin, was deposited 2.7 million years ago during the last of the major areal episodes of volcanism. A geologic map of the Burns Quadrangle has made some localized revisions of Piper et al (1939) and has renamed some of the rock formations (Greene, Walker, and Corcoran 1972). Greene (1970 has studied the lithology of ash flow tuffs in the Basin. Neim (1972) has written about Wright's Point, an interesting tongue of land now elevated but 
formerly an old river channel until filled with basaltic lava. Blank and Gettings (1973) attribute some of the tuffaceous deposits to a caldera structure found by geomagnetic anomalies.

\section{Present Climate}

Today the Harney Basin is semi-arid, with a wide daily and seasonal range in temperature, low relative humidity and high evaporation rate. Strong winds are common throughout the year, especially from March to June. In the summer the percentage of sunshine is high. Freezing night temperatures can occur in any month of the year.

Rainfall is variable throughout the basin. The average at Malheur National Wildlife Refuge Headquarters for the period from 1938 to 1977 was $22.7 \mathrm{~cm}\left(8.93^{\prime \prime}\right)$. Individual years varied from a low of $9.5 \mathrm{~cm}\left(3.74^{\prime \prime}\right)$ in 1949 to a high of $37.3 \mathrm{~cm}$ (14.70") in 1964 (Table I). The higher elevations in the basin have significantly greater rainfall, a fair portion of which accumulates as snow in the winter months. A limited sampling from Burns Mill from 1909 to 1913 showed an average of $44.1 \mathrm{~cm}$ (17.36") while Burns has one third less, $30.1 \mathrm{~cm}((11.86 ")$ for the same period. Burns Mill was located about $34 \mathrm{~km}$ (21 miles) west northwest of Burns at an elevation of $1524 \mathrm{~m}\left(5000^{\prime}\right)$ on the divide between Silver Creek and the Silvies River.

Averages taken from a number of locations in the Basin show that about one third of the rainfall occurs in the three fall months, one third more in the winter, one fourth in the spring, and about one twelfth in the three summer months. 
TABLE I

ANNUAL RAINFALL AT FOUR STATIONS IN THE

MALHEUR NATIONAL WILDLIFE REFUGE, $\mathrm{cm}$

Head-

quarters

Station

\begin{tabular}{ll} 
P-Ranch & $\begin{array}{c}\text { Double-0 } \\
\text { Station }\end{array}$ \\
\hline
\end{tabular}

Buena Vista

Station

19378.6 Incomp.

$1938 \quad 24.3$

$1939 \quad 16.3$

$\frac{1940 \quad 33.0}{1941-30.3}$

$1942 \quad 28.0$

$1943 \quad 20.0$

$1944 \quad 23.1$

\begin{tabular}{lll}
1945 & 27.0 & 33.4 \\
\hline 1946 & 21.1 & 23.9
\end{tabular}

$\begin{array}{lll}1947 & 17.7 & 26.6\end{array}$

$\begin{array}{lll}1948 \quad 26.8 & 41.1\end{array}$

$\begin{array}{lll}1949 & 9.5 & 18.2\end{array}$

$\begin{array}{lll}1950 & 22.1 & 32.2\end{array}$

195120.0

$1952 \quad 19.2$

$1953 \quad 24.0$

$\begin{array}{ll}1954 & 19.7\end{array}$

32.3

22.0 from Feb.

$1955 \quad 19.4$
1956

29.8

35.1

13.5

25.6

17.7

$\begin{array}{ll}19567 & 24.5 \\ 1957 & 28.4\end{array}$

$1958 \quad 18.4$

$1959 \quad 14.3$

25.8

14.1

$1960 \quad 26.4$

196120.9

$1962 \quad 23.6$

$\begin{array}{ll}1963 & 24.7\end{array}$

33.2

23.9

16.2

$\frac{14.9}{20.4}$

22.4

21.6

26.1

12.9

9.6 from Aug.

17.3

20.2

11.8

21.2

15.0

22.5

$1964 \quad 37.3$

26.3

31.7

18.7

32.5

26.2

15.3

$\begin{array}{ll}1965 & 22.8\end{array}$

23.0

26.0

$1966 \quad 21.5$

13.1 Incomp.

21.4

196721.3

$1968 \quad 21.5$

196921.4

24.1

27.4 Incomp. $\quad 28.0$

$1970 \quad 30.5$

197121.5

$1972 \quad 21.7$

28.0

21.6

21.8

24.5

26.1

16.6

28.5

17.3

29.9

22.9

40.3

31.3

22.9

30.0

33.5

19.6

13.5

$1973 \quad 17.2$

28.7

15.3

15.0

$1974 \quad 18.2$

19.9

11.8

12.5

$1975 \quad 27.2$

$1976 \quad 24.2$

37.7

19.8

22.5

$1977 \quad 18.8$

27.3

7.6 Incomp. 20.7 
TABLE I

ANNUAL RAINFALL AT FOUR STATIONS IN THE

MALHEUR NATIONAL WILDLIFE REFUGE, in

Head-

\begin{tabular}{lllc} 
quarters & $\begin{array}{l}\text { P-Ranch } \\
\text { Station }\end{array}$ & $\begin{array}{c}\text { Double-0 } \\
\text { Station }\end{array}$ & $\begin{array}{c}\text { Buena Vista } \\
\text { Station }\end{array}$ \\
\hline
\end{tabular}

\begin{tabular}{|c|c|c|c|c|c|}
\hline $\begin{array}{l}1937 \\
1938 \\
1939 \\
1940 \\
1941 \\
1942 \\
1943 \\
1944 \\
1945 \\
1946 \\
1947 \\
1948 \\
1949 \\
1950 \\
1951 \\
1952 \\
1953 \\
1954 \\
1955 \\
1956 \\
1957 \\
1958 \\
1959 \\
1960 \\
1961 \\
1962 \\
1963 \\
1964 \\
1965 \\
1966 \\
1967 \\
1968 \\
1969 \\
1970 \\
1971 \\
1070\end{array}$ & $\begin{array}{r}3.38 \\
9.57 \\
6.40 \\
12.99 \\
11.94 \\
11.04 \\
7.87 \\
9.08 \\
10.63 \\
8.29 \\
6.97 \\
10.54 \\
3.74 \\
8.71 \\
7.89 \\
7.54 \\
9.44 \\
7.77 \\
7.62 \\
9.66 \\
11.18 \\
7.23 \\
5.62 \\
10.41 \\
8.22 \\
9.29 \\
9.74 \\
14.70 \\
8.99 \\
8.47 \\
8.38 \\
8.48 \\
8.41 \\
12.00 \\
8.46 \\
8.54 \\
6.77 \\
7.18 \\
10.69 \\
9.52 \\
7.39\end{array}$ & 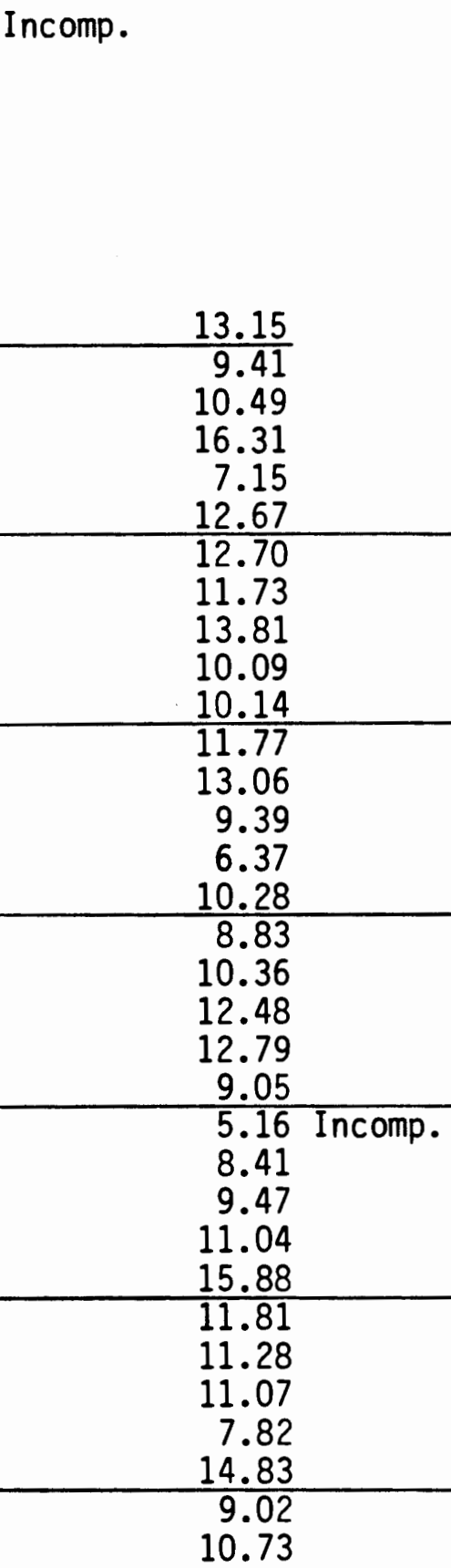 & \multicolumn{2}{|c|}{$\begin{array}{r} \\
\\
\\
\\
\\
\\
\\
\\
\\
\\
\\
8.66 \text { from Feb. } \\
7.35 \\
5.33 \\
6.96 \\
5.54 \\
5.88 \\
8.04 \\
8.80 \\
8.49 \\
5.08 \\
7.94 \\
5.91 \\
7.37 \\
10.31 \\
10.77 \text { Incomp. } \\
8.50 \\
9.65 \\
10.29 \\
11.21 \\
11.78 \\
12.32 \\
13.20 \\
7.70 \\
6.02 \\
4.63 \\
7.80 \\
10.43 \\
2.98 \text { Incomp. } \\
\end{array}$} & $\begin{array}{l} \\
\\
\\
\\
\\
\\
\\
\\
\\
\\
\\
\\
\\
\\
\\
\\
3.79 \text { from Aug. } \\
6.83 \\
4.63 \\
8.85 \\
6.13 \\
6.02 \\
10.24 \\
11.02 \\
8.6 \\
9.15 \\
6.54 \\
6.82 \\
9.03 \\
9.03 \\
8.75 \\
5.32 \\
5.90 \\
4.93 \\
8.87 \\
8.71 \\
8.13 \\
\end{array}$ \\
\hline
\end{tabular}


Annual mean temperature at Burns is about $7.0^{\circ} \mathrm{C}\left(44.6^{\circ} \mathrm{F}\right)$ with a mean daily maximum of $15.6^{\circ} \mathrm{C}\left(60.2^{\circ} \mathrm{F}\right)$ and minimum of $-1.9^{\circ} \mathrm{C}\left(28.5^{\circ} \mathrm{F}\right)$. Summer temperatures of ten approach, but rarely exceed $38^{\circ} \mathrm{C}\left(100^{\circ} \mathrm{F}\right)$. Extremes range from a low in December of $-43^{\circ} \mathrm{C}\left(-45^{\circ} \mathrm{F}\right)$ to a high in July of $41^{\circ} \mathrm{C}$ $\left(105^{\circ} \mathrm{F}\right)$.

Evaporation on the alluvial plain, measured during the April through 0ctober period, from 1914 through 1932, averaged $109.0 \mathrm{~cm}$ (42.91"). This is approximately 4.8 times the annual rainfall at this elevation. The ratio of evaporation to rainfall is of critical importance when considering the conditions that would maintain a stable major lake within the basin. (The cited figures are primarily from Piper et al 1939. Rainfall figures for Refuge Headquarters are from a personal communication from Mr. Joseph Mazzoni.)

As in most desert country, summer rainfall in particular often comes as torrential localized cloudbursts. These occasionally result in flash floods turning normally dry streambeds into raging torrents. This phenomenon is geologically important because of the heavy load of silt and rock transported from the highlands to the alluvial plains. The record of such flooding appears to be preserved in the study area.

A flash flood hit the study area on the south edge of Harney Lake about 1965. This had sufficient intensity to wash out a $1.5 \mathrm{~m}$ (5') diameter culvert crossing under the South Harney Lake Road. A similar flood took place in the early months of 1979 . This was caused by a very heavy rainfall that occurred while the ground was still frozen. Runoff was nearly total and occurred in a very short time period. The effects in the study area and at other locations in the Harney Basin were dramatic 
examples of localized severe gully cutting with heavy alluviation on the playas at the gully mouths.

Obviously, if large rocks can be transported, so can artifacts. This suggestion will be considered later as one possible explanation for the provenience of certain artifacts.

The National Oceanographic and Atmospheric Administration has prepared forecasts to estimate the frequency of occurrence of these severe incidents as an aid to watershed management (NOAA, 1973). Table II indicates maximum rainfall to be expected within any six-hour or 24-hour period at intervals of from two to 100 years. The isopluvials chosen encompass roughly the interior (lakes) area of the Basin, the alluvial plains and the high country in excess of about $1525 \mathrm{~m}\left(5000^{\prime}\right)$.

TABLE II

SEVERE RAINFALL EXPECTANCY FOR HARNEY BASIN

6-Hour Period
$\begin{gathered}\text { Basin Alluvial Higher } \\ \text { Interior Plain Elan Alluvial Higher }\end{gathered}$

$\begin{array}{lllllll}2 \text { Years } & 1.52 \mathrm{~cm} & 1.65 \mathrm{~cm} & 1.78 \mathrm{~cm} & 2.03 \mathrm{~cm} & 2.54 \mathrm{~cm} & 3.56 \\ & 0.6^{\prime \prime} & 0.65^{\prime \prime} & 0.7 " & 0.8^{\prime \prime} & 1.0^{\prime \prime} & 1.4^{\prime \prime} \\ 5 \text { Years } & 2.03 & - & 2.28 & 3.05 & 3.56 & 4.06 \\ & 0.8 & - & 0.9 & 1.2 & 1.4 & 1.6 \\ 10 \text { Years } & 2.28 & 2.54 & 2.79 & 3.56 & 4.06 & 4.57 \\ & 0.9 & 1.0 & 1.1 & 1.4 & 1.6 & 1.8 \\ 25 \text { Years } & 2.79 & 3.05 & 3.30 & 4.06 & 4.57 & 5.59 \\ & 1.1 & 1.2 & 1.3 & 1.6 & 1.8 & 2.2 \\ 50 \text { Years } & 3.05 & 3.30 & 3.56 & 4.57 & 5.59 & 6.10 \\ & 1.2 & 1.3 & 1.4 & 1.8 & 2.2 & 2.4 \\ 100 \text { Years } & 3.56 & 3.81 & 4.06 & 5.59 & 6.10 & 6.60 \\ & 1.4 & 1.5 & 1.6 & 2.2 & 2.4 & 2.6\end{array}$

Adapted from National Oceanographic and Atmospheric Administration Atlas 2, Precipitation Frequency Atlas of the Western United States, Volume X, Oregon, 1973. 
D. Past Climate

Various investigators, beginning with Gilbert (1890:275), dealt with the question of the Quaternary climates of the Great Basin. Many of these studies have been made by Quaternary geologists interested in conditions that would maintain the Great Basin lakes at their Pleistocene levels. Others have offered more general climate models which are purported to have broad areal significance. Among the latter group Antevs has had the most influence $(1948,1955)$. It is useful to look at Antevs' work from a historical point of view because it has molded much of the archaeological thinking in the Great Basin for almost four decades. Some of the more specific approaches to climate reconstruction will then be considered.

The retreat of the great continental glaciers about 12,000 years ago also marked the end of the Pluvial period in the Great Basin. Antevs (1948, 1955) divided the time from the end of the Pluvial to the present into three periods; the Anathermal, Altithermal and Medithermal. Each of these is a general climatic interval in what he termed the Neothermal. Antevs saw the Anathermal as a subhumid period, a bit moister than today. The pluvial lakes were still present although somewhat below the ir maximum extent. They were presumed to be diminishing in size particularly toward the end of the period. This was believed to be a time of grasslands with coniferous forests $500-1000 \mathrm{~m}$ lower in elevation than today. There is a presumption that the shallow water margins of the lakes were ecologically rich littoral zones, providing abundant resources suitable for human exploitation. 
The onset of the Altithermal was seen as a time of rather rapid warming and drying that began about 7000 B.P. and lasted until about 4500 B.P. It was an arid period during which the great pluvial lakes desiccated rapidly to broad sterile playas. Shrubs invaded the grasslands and the pine forests retreated to only the highest elevations.

The third period, Antevs' Medithermal, marked a climatic moderation. Some of the pluvial lakes were reborn on a much smaller scale, as were alpine glaciers in the high elevations. In general, Antevs believed that the Medithermal was characterized by a climate much like today's.

As will be discussed in more detail later, Antevs' model has been the subject of great controversy, particularly the nature or even the reality of the Altithermal period. Perhaps as are many pioneering proposals, it was naive in its simplicity and the presumption of its synchroniety over all of the Great Basin (or over all of the Northern Hemisphere). It is now becoming evident that the climate of the Recent has been much more dynamic than Antevs' model would allow (Forbes 1973:48).

Mehringer (1977) has drawn a major synthes is of Great Basin climates of the last 10,000 years. In it he used a broad diversity of recent evidence from geological and biological subdisciplines. I here quote the summary of this paper in its entirety.

The dynamic nature of Great Basin environments is apparent whether measured by geological or biological criteria. However, instability of the last 10,000 years is no more dramatic than the ecological variation encountered by Great Basin inhabitants within a single year. Variability itself may have been most important in shaping cultural or technological adaptations. There were several periods when regional climatic change was sufficient to warrant investigations of its possible influence on human populations; locally, volcanic or tectonic activity may have been even more important. 
During the last pluvial many basins, now dry and salt encrusted, were fed to overflowing by cool waters and joined by great rivers. As woodlands descended to the treeless deserts, glaciers carved beds in the snow capped mountains. Herds of camels, horses and mammoths grazed the steppes and fertile marshes. And then, within 2000 years $(12,000-10,000$ B.P.), lakes shrank, rivers ceased to flow, and springs began to dry. Plants and animals began the long retreat northward and to higher elevations and man witnessed demise of the Pleistocene megafauna. By comparison, all subsequent environmental changes have been minor.

A trend toward aridity prevailed for the next few thousand years. As lakes grew even smaller and spring discharge decreased, with the dwindling supply of pluvial age ground water, both plants and animals continued to adjust their ranges. Short term reversals of this trend probably occurred shortly before 10,000 and 8000 B.P. By 7500 radiocarbon years ago conditions were much like the present. Some researchers have suggested the persistence of extreme arid climates, hotter and drier. than the present, for the next 3000 years. Perhaps this view is oversimplified as there is some evidence for a brief increase in effective moisture sometime between 6500-5500 radiocarbon years ago. This includes plant remains from cave deposits and pollen from lakes and bogs of northwestern Utah. The pollen records from 0 'Malley shelter and 0sgood swamp also show changes at this time, and it is a time of peat growth in the spring-fed marshes of the Amargosa Desert. Considerably more data are required to establish the detailed chronology and magnitude of Great Basin climatic change from 7500-4000 B.P. As for the rest of post-pluvial time, the influence of climatic change on man is best considered in terms of evidence for its effect on local resources.

Many lines of evidence are suggestive of a significant change to more effective moisture starting about 4000-3000 B.P. and ending before 2000 B.P. At this time minor changes to deeper lakes are recorded from Great Salt Lake, Pyramid Lake, Searles Lake and Death Valley. In the north, pollen records reveal an increase in arboreal types, and in the White Mountains there is a lowering of the bristlecone pine tree line. These events are accompanied by changes in eolian activity and from erosion to deposition and soil development.

It becomes more difficult to make broad regional generalizations as the data become more abundant. Fortunately, tree-ring studies probably will establish regional climatic patterns for the last 2000 years in a more precise manner than is otherwise possible (LaMarche 1974). During the past 2000 years, as during the preceding 10,000 , there was geological and biological instability of sufficient magnitude to affect the abundance of local resources. The evidence includes plant macrofossils from caves of northwestern Utah, suggestive of a significant moist interval 1500-600 B.P. Fluctuations in lake levels, lowering of tree 
line, renewed dune activity and stabilization, peat formation in desert salt marshes, arroyo cutting and filling and significant tectonic and volcanic activity all continued through the past 1000 years ( $p p$ 148-149).

The data from the present study bear only on the early part of the Recent but tend to confirm that this was not a time of linear climatic change.

I will now consider some examples of more specific studies aimed at finding conditions that would support the extensive lakes in the now mostly dry basins. At first look this would seem to be a rather simple and straightforward thing to do. Broecker and Orr (1958) give a simple equation relating lake area to annual averages of rainfall, evaporation and the fraction of terrestrial precipitation reaching the lake as runoff. Area for any given lake level can be estimated from topographical maps, if not already reported in the literature. Assumptions can then be made for the other three variables. A series of curves are then plotted showing conditions that would maintain the lake at a given level. Increases in rainfall or runoff and decreases in evaporation, or some combination of these, would tend to raise lake levels.

Broecker and Orr's equation is as follows:

Area lake $=\frac{\text { Runoff Fraction }}{(\text { Evaporation/Rainfall })+\text { Runoff Fraction }-1} \times$ Area Basin

Figure 4 shows a graph of conditions necessary to keep the Harney Basin filled to the overflow level of $1253.9 \mathrm{~m}(4114 \mathrm{ft})$. The upper horizontal line represents present annual evaporation on the playas, estimated at $109.0 \mathrm{~cm}(42.9 \mathrm{in}$.$) . The left vertical line is an estimate$ of present average annual rainfall over the basin of $27.2 \mathrm{~cm}(10.7$ in.) (from available data 1867 to 1932 in Piper et al 1939). Triangles defined 


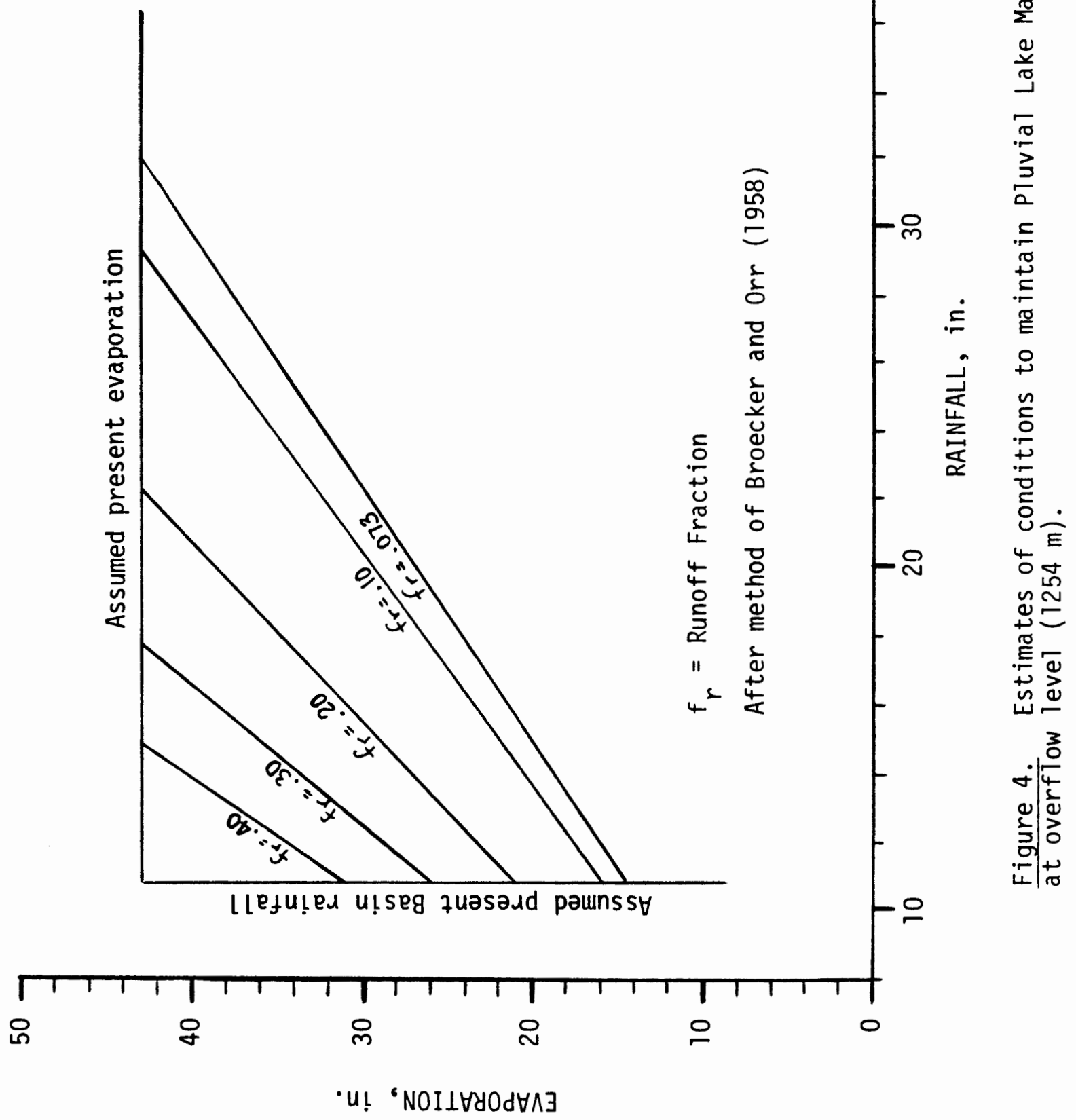


by the series of runoff 1 ines include around their periphery all sets of rainfall and evaporation conditions that would maintain the lake at the given level. As an example, with a runoff factor of 0.20 , Bas in overflow level of $1253.9 \mathrm{~m}(4114 \mathrm{ft}$ ) could presumably be maintained with the present rainfall if evaporation was reduced to $53.3 \mathrm{~cm}$ (21 in.) annually. A rainfall of $40.6 \mathrm{~cm}$ (16 in.) and evaporation of $78.7 \mathrm{~cm}$ (31 in.) would accomplish the same result.

Unfortunately, this model is rather badly oversimplified. While it defines sets of limiting conditions that could maintain a lake at some given level, it does not say what these conditions actually were. At best, it is dependent on estimates of critical parameters that are difficult to make and that may or may not approximate actuality. As an example, there is the presumption that rate of evaporation from the surface of a standard $6 \mathrm{ft}$ blackened land pan having an area of $2.62 \mathrm{~m}^{2}$ is the same as the rate of evaporation from a lake surface perhaps $350 \mathrm{~km}^{2}$ in extent.

Rainfall expressed as an average over the entire basin is not a straightforward determination to make. An accurate value cannot be obtained simply by averaging readings from various weather stations in a basin. Snyder and Langbein (1962), attempting to determine rainfall over the basin of Spring Valley, Nevada, derived a weighted average based on estimated rainfall for each of ten equal area elevation zones. While this would certainly improve the accuracy of their estimate of today's conditions over a simple averaging method, it might be noted that in the Harney Basin rainfall averages at the playa elevation differ by a factor of over 1.4 (Table 1). These figures can be summarized as follows for four 
stations for 17 years from 1958 through 1976, excluding 1964 and 1966 where records are incomplete.

$\begin{array}{lll}\text { Headquarters } & 22.1 \mathrm{~cm} & (8.71 \mathrm{in}) \\ \text { P-Ranch Station } & 26.5 \mathrm{~cm} & (10.43 \text { in) } \\ \text { Double-0 Station } & 22.3 \mathrm{~cm} & (8.76 \text { in) } \\ \text { Buena Vista Station } & 18.7 \mathrm{~cm} & (7.36 \mathrm{in})\end{array}$

Averaging values as diverse as these within a given elevation zone may give sufficient accuracy but this has not been demonstrated in the 1iterature. It appears that there is a need both for data from more weather stations and for computer modeling of the basins if dependable accuracy is to obtained for values of average basin rainfall.

Runoff fraction is perhaps the most elusive factor required in the Broecker and Orr model. It is dependent on a multitude of intangible variables that occur both within and between basins. Factors such as amount and type of vegetation, soil condition at the time of rainfall, the nature of the rainfall itself, and type of feeder stream systems within the basins will all have major effect. Snyder and Langbein 1962: 2390) cite runoff fractions varying from 0.01 to 0.37 in different western watersheds.

The major area of the Snyder and Langbein study, Spring Valley, Nevada, appears to have a climate quite similar to the Harney Basin. The authors conclude that the Pleistocene level of the lake could have been maintained by any combination of basin precipitation and evaporation that satisfied a ratio of about 0.65 . They further feel that the most likely conditions were a decrease in evaporation from the present $117 \mathrm{~cm}$ to $87 \mathrm{~cm}$ (46 in. to $33 \mathrm{in.}$ ) and increase in present precipitation from $31 \mathrm{~cm}$ to $51 \mathrm{~cm}$ (12 in. to $20 \mathrm{in.})$. This would represent a $550 \mathrm{~m}(1800 \mathrm{ft})$ 
elevation depression of present rainfall patterns. After reporting these values, the authors give a warning that represents unusual candor in any scientific study:

The effects of possible changes in precipitation intensities or of the seasonal pattern of precipitation have not been investigated because, as it must be emphasized, the findings already represent a chain of speculations that may strain the available evidence (Snyder and Langbein 1962: 2393).

Another approach to the problem would correlate the historic levels of closed basin lakes with streamflow records. This approach was used by Hardman and Venstrom (1941) and much more superficially by Harding (1942) in a study of Pyramid and Winnemucca Lakes in Nevada. The Truckee River, heading in Lake Tahoe on the crest of the Sierra Nevada, is the only important stream entering the lakes. At high water levels the two lakes are connected, although Winnemucca Lake is a mudflat at present. Historic records of various types extend back, with many gaps, to 1839. Hardman and Venstrom succeeded in making a correlation between runoff and lake level, but this reflects weather only in the period of the study. They found no good mechanism for projecting back in time.

It is worth noting that during the century covered by the above study there were major drought periods inferred prior to 1840 and from 1917 to the conclusion of the study in 1939. Conversely there was a wetter than normal period from 1860 to 1917 . It is important that these generalizations are not misinterpreted. Reference to Figure 5 (p 88) of the Hardman and Venstrom paper shows their estimated percent of average runoff for each year of this century long period. This is reproduced here as Figure 5. The carrying capacity of land for humans or animals is limited by the most stressful situations that can be endured. Years like 


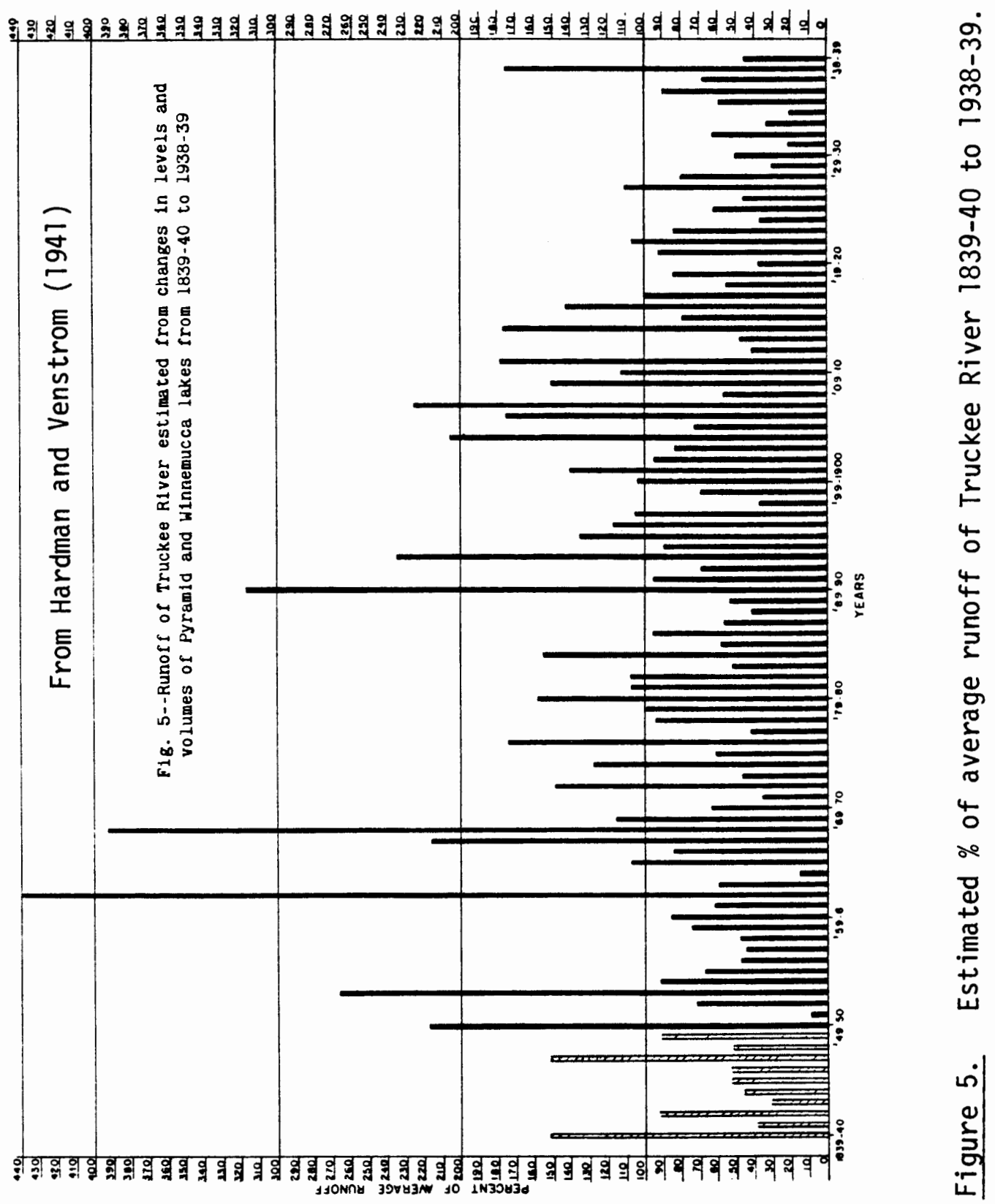


1850-51 and 1963-64, when precipitation was judged to be only about $10 \%$ and $14 \%$ of normal, could have imposed far more stress on populations than much longer periods when precipitation was uniformily about half of normal; e.g., 1957-60, but may have been more dependable.

One of the most reliable routes to paleoclimates is tree ring studies. Such a study was made in the Harney Basin by L. T. Jessup (Piper et al 1939: 10-13). Unfortunately, this study was made on only four trees from widely scattered sites. Even so, he does show a good correlation of tree growth with rainfall in the 1900-1930 period. The conclusions of the study showed lower than normal rainfall for 25 year periods every 70-90 years. This study must be regarded with considerable suspicion because of the small number of samples and lack of explicit data on which conclusions were based. Fritts (1971) points to pitfalls in interpretation of rainfall from the ring data.

A much more extensive study for eastern Oregon was made by Keen (1937). Keen's data begin at 1268 AD. He concludes that "no evidence either for or against predictable [wet or dry] cycles has been found" (p 184). This was based on a study of 1240 ponderosa pines from 44 localities. He notes poor growth periods of "short duration but great intensity," a finding in concert with those of Hardman and Venstrom. He further notes that the drought of 1917 to 1936 greatly exceeds that of any other period in cumulative rainfall deficiency.

Keen's conclusions were largely supported by an earlier tree-ring study by Bowman (1935). Bowman specifically comments on Goose Lake which spans the border between southcentral Oregon and northeastern California. This lake was dry when the early American explorers passed through just 
prior to the mid 1800s. It was reborn shortly after this period and persisted until the 1920s when it again became desiccated. Shinn (1977) describes the effect of these relatively short-term climate fluctuations on vegetation, particularly the juniper line.

Fritts (1965, 1971) reports much more sophisticated tree-ring studies of the western United States in which he projects rainfall back by decades for several centuries. Again there is no significant variance with the conclusions drawn earlier by Keen. In the time period covered there does not seem to be predictable wet or dry patterns.

It should be apparent from these remarks that there is no easy route to paleoclimates. It is an extremely complex subject that must be approached from many fronts. Little is yet resolved or clear except that most of the great Pleistocene lakes are now dry playas, and this drying occurred in one or more episodes after 8000 B.P. A second point is that short term climate variations may well be of as great or greater importance to human occupation than long-term trends.

\section{E. Hydrology}

Virtually all of the water now reaching the alluvial plain in the Harney Basin, other than direct rainfall, is supplied by three stream systems. The two larger streams, the Silvies River and Donner und Blitzen River, are tributaries of Malheur Lake. Silver Creek is the only stream of importance to enter Harney Lake directly although it yields significant water to the playa only in very wet years.

Malheur ${ }^{2}$, Harney and Silver Lake playas are the principal remnants of the great Pleistocene lake that once occupied most of the area of the present alluvial plain. Malheur Lake is the largest of these. It is very 
shallow, not exceeding about three meters in depth at its maximum extent. The shorelines are very gently sloped so that the lake varies enormously in area, depending on water level. In 1952, and again in 1979, it was estimated to have reached an area of $270 \mathrm{~km}^{2}\left(105 \mathrm{mi}^{2}\right)$ and a surface elevation of $1248.27 \mathrm{~m}(4095.39 \mathrm{ft})$ above sea level. This is the highest water level noted in the approximately half century in which accurate records have been kept. In contrast, in 1889, 1917 and 1930-33, Malheur Lake was virtually dry (Duebbert 1969).

Not only is the year-to-year variation in area substantial, but variation during the year can also be great. In 1903, as one extreme example, the lake area was only $8.1 \mathrm{~km}^{2}\left(3.1 \mathrm{mi}^{2}\right)$ early in the year when the lake gauge read $1246.4 \mathrm{~m}(4089.3 \mathrm{ft})$ elevation. After the freshets in April and May the lake had expanded to $259 \mathrm{~km}^{2}\left(100 \mathrm{mi}^{2}\right)$ and stood at $1248.2 \mathrm{~m}(4095 \mathrm{ft})$. In terms of water volume this represents an increase of about $2.57 \times 10^{8} \mathrm{~m}^{3}(208,000$ acre feet $)$. By winter of the same year the area had dropped to $199 \mathrm{~km}^{2}\left(77 \mathrm{mi}^{2}\right)$ at a level of $1247.5 \mathrm{~m}$ (4093 ft) (Piper et al 1939). Some of this water would have been lost by overflow into Harney Lake; while the rest was lost by evapotranspiration from both lakes.

When the water level in Malheur Lake exceeds $1247.1 \mathrm{~m}(4091.5 \mathrm{ft})$ it overflows through the channel at the Narrows into Mud Lake. If the water level rises above $1247.7 \mathrm{~m}$ (4093.5 ft) Mud Lake overflows at Sand Gap into Harney Lake, the lowest part of the Basin (Piper et al 1939).

2In the present study I will normally treat Mud Lake, an ephemeral westerly lobe of Malheur Lake, as a part of the latter lake. Mud Lake is often considered separately in the literature of the Basin. It lies between the main body of MaTheur Lake and Harney Lake. 
Harney Lake is contrasted with Malheur in that it is relatively steep-sided. When it does contain water it is of relatively constant area, regardless of internal water volume. Figure 6 shows areas and capacities of this lake system at various water levels. These curves from Piper et al (1939) form the present day basis for estimation of surface area of water in Malheur Lake. Any original inaccuracies will remain in these later data.

Harney Lake provides the ultimate sump for all excess water entering the Basin. When it does contain water, it is charged with alkaline salts, principally a mixture of $\mathrm{NaCl}, \mathrm{NaHCO}_{3}$ and $\mathrm{Na}_{2} \mathrm{CO}_{3}$. An analysis of a sample of the salt crust taken from Harney Lake playa is given in Table 3.

A most helpful resource on the hydrology of the Basin was published by the Oregon State Water Resources Board (Oregon, 1967). Unless otherwise indicated the following data on stream hydrology are drawn from this publication.

The Silvies River is the major stream in terms of water yield to the Basin. It has its headwaters in the Strawberry and Aldrich Mountains in Grant County on the north edge of the Basin. The Silvies system, which also includes a few minor streams such as Poison Creek east of Burns, drains about $5449 \mathrm{~km}^{2}\left(2104 \mathrm{mi}^{2}\right)$. The most important part of the Silvies River as a water contributor, that lying above the alluvial plain, drains approximately $2420 \mathrm{~km}^{2}\left(934 \mathrm{mi}^{2}\right)$.

Second in importance, as far as total water contribution is concerned, is the Donner und Blitzen River originating on Steens Mountain in the southeast corner of the Basin. The drainage area of this stream above the alluvial plain comprises only about $518 \mathrm{~km}^{2}\left(200 \mathrm{mi}^{2}\right)$. From this 


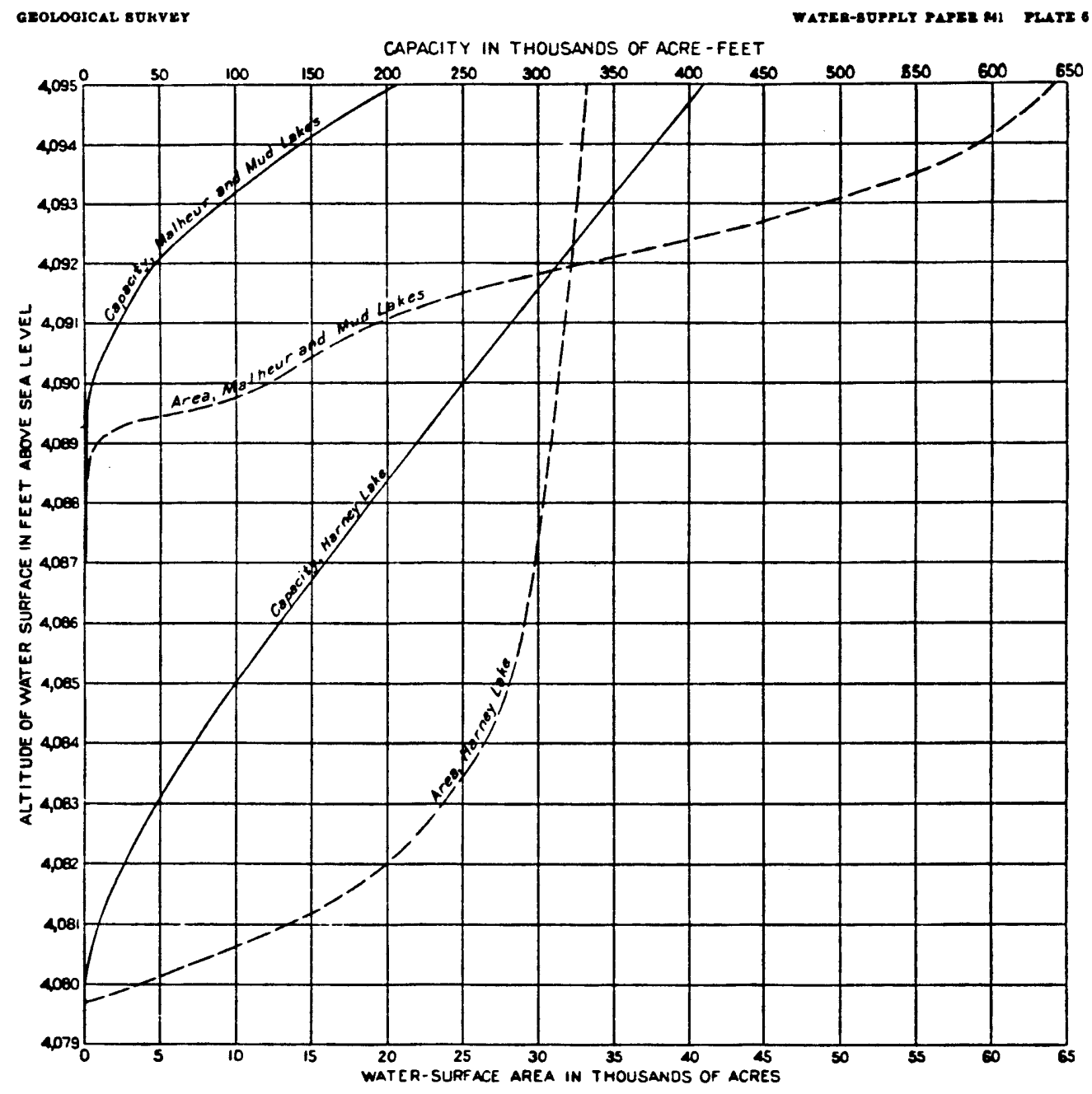

AREA AND CAPACTTY CURVES FUK MALHEUK, MUD, AND WARNEY LAKES, HARNEY COUNTY, OREG.

Figure 6. Surface area vs. water capacity of MaTheur and Harney Lakes.

From Piper et al (1939) 
TABLE II I

ANALYSES OF SALT CRUST FROM HARNEY LAKE PLAYA

Element

Carbonate $\left(\mathrm{CO}_{3}^{=}\right)$*

Sodium

Sulfate $\left(\mathrm{SO}_{4}^{=}\right)$

Chloride

Sulfur

Silica $\left(\mathrm{SiO}_{2}\right)$

Boron

Potassium

Phosphorus
Percent of

As-Received

Sample

19.9

14.2

6.23

5.95

2.20

0.17

0.14

0.13

0.11
Element

Arsenic

Calcium

Vanadium

Molybdenum

Magnesium

Iron

Strontium

Copper

Manganese

Barium

Mercury

Uranium

Antimony

Bismuth

Lead

Aluminum

Tin

Silver, Nickel

Chromium

Tungsten, Zinc

Cobalt, Cadmium

Beryllium $\mathrm{ppm}$ or $\mathrm{mg} / \mathrm{kg}$ of

As-Received Sample

60.0

40.0

5.8

4.6

2.5

0.9

0.4

0.3

0.2

0.2

$<3.0$

$<2.0$

$<1.6$

$<1.1$

$<0.8$

$<0.8$

$<0.3$

$<0.2$

$<0.2$

$<0.1$

$<0.1$

$<0.1$

*0f total $\mathrm{CO}_{3}=$ about $72 \%$ is present as $\mathrm{CO}_{3}=$ and $28 \%$ as $\mathrm{HCO}_{3}=$

This sample was taken between two of the barrier islands enclosing the lagoon off the study area. I am grateful to Charles Worley and Weyerhaeuser Company for the above analyses. 
relatively small accumulation zone, it has an average annual water yield to the Basin interior which is about two thirds that of the Silvies River. It is a more dependable stream with year-around flow, while the Silvies River is often completely dry in the summer months. These characteristics are due to the relatively high winter snow accumulation on Steens Mountain. On sheltered upper slopes snow patches often remain well into the summer.

Several significant smaller streams originating on the west slope of Steens Mountain are indirectly tributary to the Donner und Blitzen River in the Blitzen Valley. Mud and Bridge Creeks flow into the P Ranch Swamp immediately north of Frenchglen. Together with other minor streams they drain an area of $413 \mathrm{~km}^{2}\left(159 \mathrm{mi}^{2}\right)$. Krumbo Creek is tributary to the main stem of the Donner und Blitzen north of the P Ranch Swamp. Diamond Swamp is fed principally by McCoy, Cucamonga and Kiger Creeks. This last group of four streams have a drainage area of $518 \mathrm{~km}^{2}\left(200 \mathrm{mi}^{2}\right)$, almost identical to the main stem headwaters of the Donner und Blitzen.

Silver Creek lies in the drainage immediately to the west of the Silvies River. Its drainage system comprises $5288 \mathrm{~km}^{2}\left(2041.7 \mathrm{mi}^{2}\right)$, a figure almost identical to that for the Silvies system. Of this, about $1390 \mathrm{~km}^{2}\left(536 \mathrm{mi}^{2}\right)$ lies in the critical headwaters area. As a result of this smaller (57 percent) and, more importantly, much lower headwaters area, Silver Creek contributes only about one fifth as much water to the Basin as does the Silvies River. Under flood conditions, the flow of Silver Creek splits, with part going to Silver Lake playa and the balance to Harney Lake via the Warm Springs Valley. In extremely wet years, Silver Lake will fill to overflowing and contribute its runoff to Harney 
Lake. Excess water rarely reaches this area today because of a series of dams on Silver Creek and its major tributaries for impoundment of irrigation water.

The average annual outflow of the Silvies River above Burns over the years $1935-1964$ was $1.57 \times 10^{8} \mathrm{~m}^{3}$ (127,200 acre feet). About 80 percent of this is from high country snow melt in March, April and May, with a peak in mid-April. In this 30-year period outflow has varied from a low of $5.45 \times 10^{7} \mathrm{~m}^{3}(44,170$ acre feet $)$ to $3.34 \times 10^{8} \mathrm{~m}^{3}(270,400$ acre feet $)$, a factor greater than 6 .

In the period from 1951 to 1964 Silver Creek averaged an annual contribution of $3.63 \times 10^{7} \mathrm{~m}^{3}(29,400$ acre feet $)$. The runoff pattern of Silver Creek closely parallels that of the Silvies River.

The other major water contributor, the Donner und Blitzen River, yielded at Frenchglen an average annual outflow to the Basin of $1.04 \times 10^{8} \mathrm{~m}^{3}(84,000$ acre feet) during the 1935-1964 period. It is a more reliable stream than the others, not only in terms of year-to-year variation but in dependability. Both Silver Creek and the Silvies River are frequently dry near the end of the summer, even in normal rainfall years. The Donner und Blitzen has maintained a small flow even in extreme drought years, an important factor for human occupation both in aboriginal and modern times (Oregon, 1967:28). It is probably safe to infer that the Donner und Blitzen was a dependable source of water even in the driest periods of the past millenia. In addition, its population of freshwater mussels has been an important food resource to aboriginal desert peoples.

A clear picture of the criticality of elevation to precipitation over the Basin can be seen by reference to Wilson and Buzzard Creeks. 
These two ephemeral streams also potentially supply water to Silver Lake Playa. Their drainage area comprises a substantial $1813 \mathrm{~km}^{2}\left(700 \mathrm{mi}^{2}\right)$, most of which is below $1524 \mathrm{~m}(5000 \mathrm{ft})$ elevation. Yet only on the rare occasions of localized cloudbursts is their flow ever sufficient to reach Silver Lake.

One other stream also enters Harney Lake directly. Jackass Creek has not even been mentioned in any of the publications dealing with the water resources of the Harney Basin. Along with an unnamed former tributary whose mouth is now drowned by alluvium, it has a modest drainage area of $290 \mathrm{~km}^{2}\left(112 \mathrm{mi}^{2}\right)^{(1)}$. It is of importance today only as a source of irrigation water for a small playa called Weed Lake Flat. Jackass Creek merits comment at this point only because its alluvium-filled estuary forms the major study area of this project.

\section{F. Human Occupation - Archaeology}

The story of human occupation in the Harney Basin prior to historic times is an unwritten chapter in man's long occupation of the northwestern Great Basin. It is unwritten largely because it is unknown. The first Harney County site was not even registered until about 1970 . In the intervening decade almost 400 sites have been listed for the Basin on the Oregon registry, although this is undoubtedly but a small percentage of the total. Many of these sites were found during a survey of the Malheur National Wildlife Refuge in 1972-74. Reports of this are on file with the Refuge superintendent. Others have been recorded only because of the

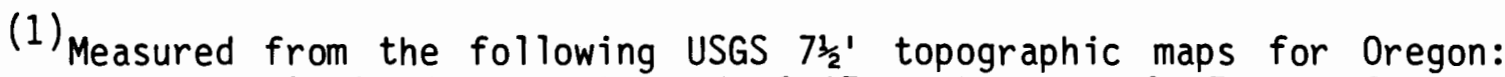
Coyote Butes 1976; Jackass Mountain 1967; Irish Lake 1967; Keg Springs Valley East 1971; Keg Springs Valley West 1971; and five untitled preprints currently designated Harney Lake 3NE, 4NE, 4NW, 4SE and 4SW. 
recent requirements for staff archaeologists in many state and federal agencies.

Despite the large numbers of sites, there has been only the barest minimum of work in the Basin other than site survey. Test excavations of sites at Hogwallow Springs, 35HA8, and Blitzen Marsh, 35HA9, were made by Fagan (1974) along with work in other areas of southeast Oregon. These are the only sites that have been even minimally reported in the generally available literature.

Some salvage archaeology has been done in the headquarters area of Malheur National Wildlife Refuge at a deep end extensive stratified site, 35HA403. This has been reported in manuscript form to the Refuge superintendent (Benson 1979, Campbell 1980).

For the moment then, the prehistory of the Harney Basin must be denied its rightful individuality and lumped into the broader prehistory of the northern Great Basin. There is some hazard in this for a number of reasons. As I have already pointed out, the Harney Basin fits only marginally into the physiographic and ecological descriptions of the American Great Basin. It is culturally marginal as well, since it is on the artificial borderline between Desert and Plateau cultures (Driver 1969).

Through the early decades of this century, in fact until the folsom finds in 1926 and 1927, man was presumed to be a late occupant of North America. Even though his association with now-extinct big game was proved, authorities were unwilling to accept his presence in the Great Basin for more than a couple of thousand years at most. Luther Cressman 
challenged this dictum after his work at a number of rockshelter sites in the Fort Rock Basin, including the famous Fort Rock Cave. He stated:

Work at this last site [Paisley Five-Mile Point No. 3] shows that man and an extinct fauna occupied this region of southern Oregon at some fairly remote time, probably toward the end of the last pluvial something more than 10,000 years ago. This evidence... shows that human occupation of the northern basin has been continuous since that period. (Cressman 1942:94)

Cressman was severely attacked from a number of quarters for this heresy. Obviously time has proved him to be right. The work that led to this report was one of the first interdisciplinary studies in New World archaeology and Cressman's conclusions were based on sound geological and palynological grounds which he used to support his archaeological findings.

It can now be rather safely assumed that man has been present in the Great Basin as long as in any of the other unglaciated areas of North America. New and very solid ${ }^{14} \mathrm{C}$ dates from the Fort Rock Basin (and across the Great Basin as a whole) show his presence between 11,000 and 12,000 years ago, possibly as early as 13,200 B.P. to 14,500 B.P if controversial dates from Fort Rock Cave and Wilson Butte Cave are accepted (Bedwell 1969, Bedwell and Cressman 1971, Gruhn 1965).

There is a common presumption that man at this time, and until about 8000 B.P., had a subsistence pattern heavily dependent on big game hunting. The evidence for this comes mainly from a number of kill sites in the southwest and on the plains just east of the Rockies. Without arguing the thinness of the evidence for this presumption, it is clear that in the Great Basin his campsites are almost universally found adjacent to Pleistocene lakeshores and associated streams. This speaks strongly to 
heavy utilization of the resources provided in these environments. Between 8000 and 7000 B.P. there was a major shift in settlement patterns and sites are found widely dispersed and at all elevations (Grayson 1979). The lanceolate projectile points of the earlier period largely disappear and are replaced by smaller and more varied types. A significant addition to the tool kit at this time are seed grinding tools; the mano and metate. Before 8000 B.P. they were rare to absent. After that time they become increasingly important (Bedwell 1973, Jennings 1974, Pettigrew 1975, Cressman 1977). In some areas this dispersion away from lakesides did not occur until much later (Madsen and Berry 1975). Where lake or marsh resources continued to exist, it is apparent that stable base settlements also continued. This is attested to by the deep open sites on the edges of many marshlands. What little work has been done on these shows both cultural stability and continuity over long periods of time (Fagan 1974, Weide 1974).

This seems an opportune time to introduce another picture which has heavily colored our impressions of the desert peoples. To the early travelers and settlers these people were "diggers," culturally deprived subhumans whose every moment was spent merely ekeing out a bare survivallevel existence. In his ethnographic studies of the northern Paiute Julian Steward deflated the stereotype of cultural deprivation but he did little to alter the picture of the Great Basin peoples being nomads without permanent home bases (Steward 1938).

In 1955 Jennings and Norbeck presented their concept of the "Desert Culture" as ". . a desert way of life fundamentally like that of historic times"; i.e., small bands without a fixed base making full and 
intensive utilization of all available resources. There was presumption of a core of traits that were shared by all desert people and presumption of great time depth and stability in the desert way of life. This was a useful culture historical synthetic framework at the time that helped to tie together all of the jumble of reports and opinions then existent. Jennings later modified these views slightly and adopted the new term "Desert Archaic" as an organizing concept (Jennings 1964). Cressman adds his own recent comments to this:

[I] t is quite clear that Jennings and $I$, as well as others, have insisted on these two characteristics of the Great Bas in culture: a basic similarity in the area founded on the adaptive processes for survival, and regional variation on the basic pattern in different ecological areas. The idea one often hears expressed that the Great Basin culture was a monotonously uniform expression of human activity - has no basis in responsible literature on the subject. $(1977: 145)$

The shift in settlement patterns between 8000 and 7000 B.P. correlates well with what we now know about climate changes. It is now voluminously documented that a general warming trend, probably with somewhat decreased rainfall, occurred about 12,000 years ago. There is little evidence that the desert environment was anything except reasonably benign until a second shift to warmer and dryer conditions occurred about 8000-7000 years ago (Sears and Roosma 1961; Morrison 1961, 1965; Broecker, Ewing and Heezer 1960; Mehringer 1977, as examples).

The effect of this second climatic change on human occupation in the Great Basin (or whether it even occurred at a11) has been the subject of long and sometimes acrimonious debate in the archaeological literature for over three decades. A less well-resolved point that has had equal 
disagreement is whether the climatic moderation presumed to have occurred about 4500 years ago was in fact a reality.

Over the years of these debates, many authorities have insisted that a near to total depopulation occurred in many areas of the Great Basin during the Altithermal. Only during the Medithermal do they see people beginning to drift back (Baumhoff and Heizer 1965). Jennings (1974:166) has taken a diametrically opposite view and insists that there has been essentially no climatic change over the last 10,000 years that would affect man's presence. While it is clear that two camps still exist on the subject, the matter seems to have faded in recent years as new climatic evidence such as that summarized by Mehringer 1977 becomes available.

Relative to other parts of North America, very few open sites have been dug in the Great Basin. It is agreed that deep sites are in the great minority compared with surface sites, but they do exist. There are at least three large open sites having cultural material up to two meters deep within the Malheur National Wildlife Refuge. In the past, with a few notable exceptions such as Fagan (1974), these have been largely ignored in favor of dry caves and rockshelters. The attention given to these latter types of site is quite understandable. They are usually rich, not only in lithics but in perishable goods that have long ago disappeared in the open sites. They invariably contain material datable by radiocarbon techniques. This can be seen as a curse as well as a blessing because virtually all of our dates in the Great Basin used for typological cross dating come from cave sites. 
Caves and rockshelters represent only a tiny percentage of the total Great Basin sites. Their place in the lifeways of the people and in the archaeology of the Great Basin has undoubtedly been badly overemphasized. Virtually all of the evidence for Altithermal abandonment is from cave sites. When taken as a whole, this evidence is thin indeed. Clear suggestions of Altithermal abandonment comes from only two areas; the Fort Rock Basin and the Lahontan Basin, particularly in the Humboldt River drainage. The Fort Rock Basin is a special case because it had imposed on it at the same time a heavy ash and pumice fall from the cataclysmic Mt. Mazama eruption of about 7000 B.P. This must have caused ecological havoc which took centuries for full recovery (Bedwell 1973, but see also Grayson 1979).

Rockshelter sites have served one particularly valuable function. The wealth of perishable goods they have yielded have given us a far better look at the people who occupied them. These have shown beyond any doubt that the life of these desert dwellers was far richer than could be expected if all of their energy had been directed solely into a day-afterday battle for survival. 


\section{THE SOUTH HARNEY LAKE PROJECT}

A. Introduction - the Problem and Approach

This project had its genesis in the chance finding of two artifacts in the wall of a long man-made arroyo on the south edge of Harney Lake, Oregon. The occasion was an exploratory trip of the class in archaeological field methods at the Malheur Field Center in August 1975.

In short order the artifacts were removed, unfortunately rather carelessly. No photographs were taken and orientation was not noted. It is not clear whether they were really in situ or had sloughed down from the surface on a mud flow.

The point base was a Humboldt Concave Base, Type A, a type of considerable antiquity (Clewlow 1967, 1968). Geologic context of the find also suggested considerable age. The artifacts apparently lay on or just above the old lake bottom, over six meters above the present Harney Lake playa. Although this interpretation has now been modified, it appeared then that the silt overlying the artifacts had been deposited during a later rise in lake level.

Were the points merely a chance isolated find or did they indicate a larger site, possibly even an early man camp? The latter possibility seemed attractive enough to gamble on a serious exploratory probe. It looked as if at the same time this might shed some light on the late Pleistocene pluvial lake in the Harney Basin. A success on either score would more than justify the effort.

In total, 82 man-days were spent in field work on the project, not counting some time contributed by the field school at the Malheur Field Station. The comments that follow in this section are an overview of the 
approach to the project. They serve as background for the more detailed treatment that will follow.

The Humboldt point base found in the ditch bank on the south edge of Harney Lake set off a chain of speculation. Even though it lay on top of a bed of water-deposited gravel the point had not been stream rolled. That fact was first assumed to mean that it had not been water-transported either. I now challenge that assumption since the point was in gravelly silts that could hardly have had any depositional history except strongly running flood waters. The matter is largely immaterial now. But originally, the possibility that the point base and the midsection fragment found so close to it might be the outcropping of a datable early site seemed too appealing not to follow up. Searching out such a possibility was one of the original purposes of this project. The second was to shed light on the Pleistocene/Holocene history of the pluvial lake as it might be revealed in the gravel and soil deposits.

The site ${ }^{(3)}$ location is shown in Figure 7. My original plan was to sample the area adjacent to the point find with a modest checkerboard of test pits sunk to the top of the heavy gravel lying immediately below the point. If additional cultural material of any kind was found, the site could be considered a reality. Further excavation, if any, would have been guided by what was found in the field. No elaborate excavation was anticipated or would even have been possible due to lack of resources.

(3) "The site" is a term that will be heavily used and so it needs clear definition. The term has two implications. First, it includes all of the ditch itself, a ribbon of land five to ten meters wide and roughly 1500 meters long. Second, and more conventionally, it includes an area of about 250 meters radius centered on the location of the original artifact find. This latter usage is the one officially reported and assigned site number 35HA342. Regrettably, no one could think of a better name for it than a rather inglorious "The Ditch Site." 


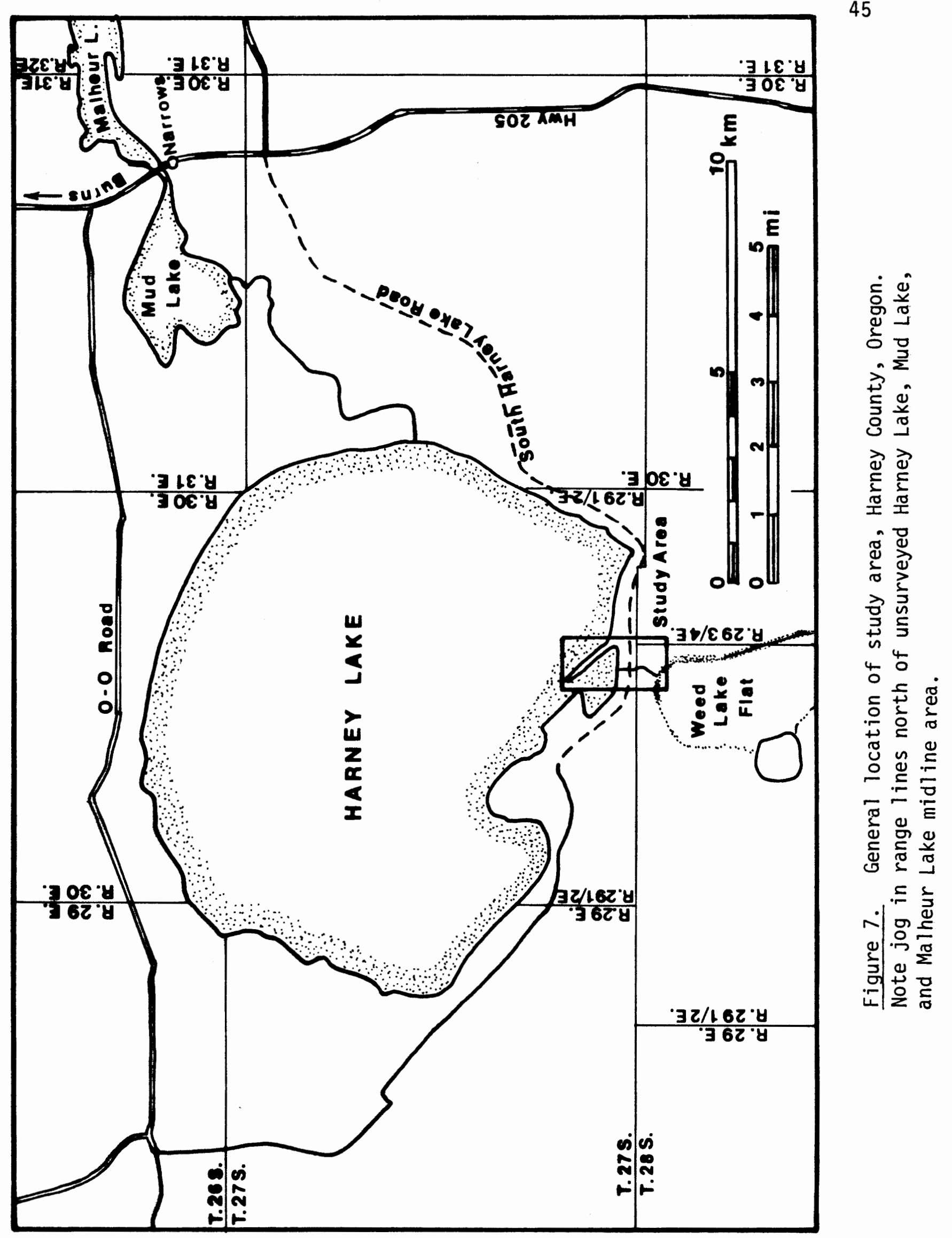


The second part of the plan involved surveying, leveling, stratigraphic mapping and ultimate interpretation of the cut exposed in the drainage ditch. This part of the job was made immeasurably easier by a series of new benchmarks, aerial photographs, and preliminary prints of U.S. Geological Survey $7-1 / 2$ ' topographic maps of the area.

Finally, it almost goes without saying that an archaeological survey of the area was essential. Two nearby sites were known from an earlier survey of the Malheur National Wildlife Refuge but these had never been evaluated in any manner.

Ultimately, there was an ambitious hope of tying any archaeological and geologic discoveries together into some sort of synthes is that might have broader applications in the Harney Basin.

The area in which the site is found was at one time a long narrow embayment of Pluvial Lake Malheur (Figure 8). At the time the Basin was dammed by the lava flow across Malheur Gap this embayment marked the course of Jackass Creek north of the deep fault line canyon it now flows through. It is slightly over $9 \mathrm{~km}(5.6 \mathrm{mi})$ from the the mouth of the canyon to the strandline marking the last stand of the pluvial lake. This embayment must have been largely, but not completely, filled with deposits carried in by Jackass Creek from the highlands when the first men walked in the area. Quite possibly at that time there were two lakes here. South of the immense Pluvial Lake Malheur there appears to have been a much smaller lake or marsh occupying the general area now known as Weed Lake Flat. Weed Lake was apparently created at least 9000 years ago behind a beach ridge thrown up by Lake Malheur across the embayment 


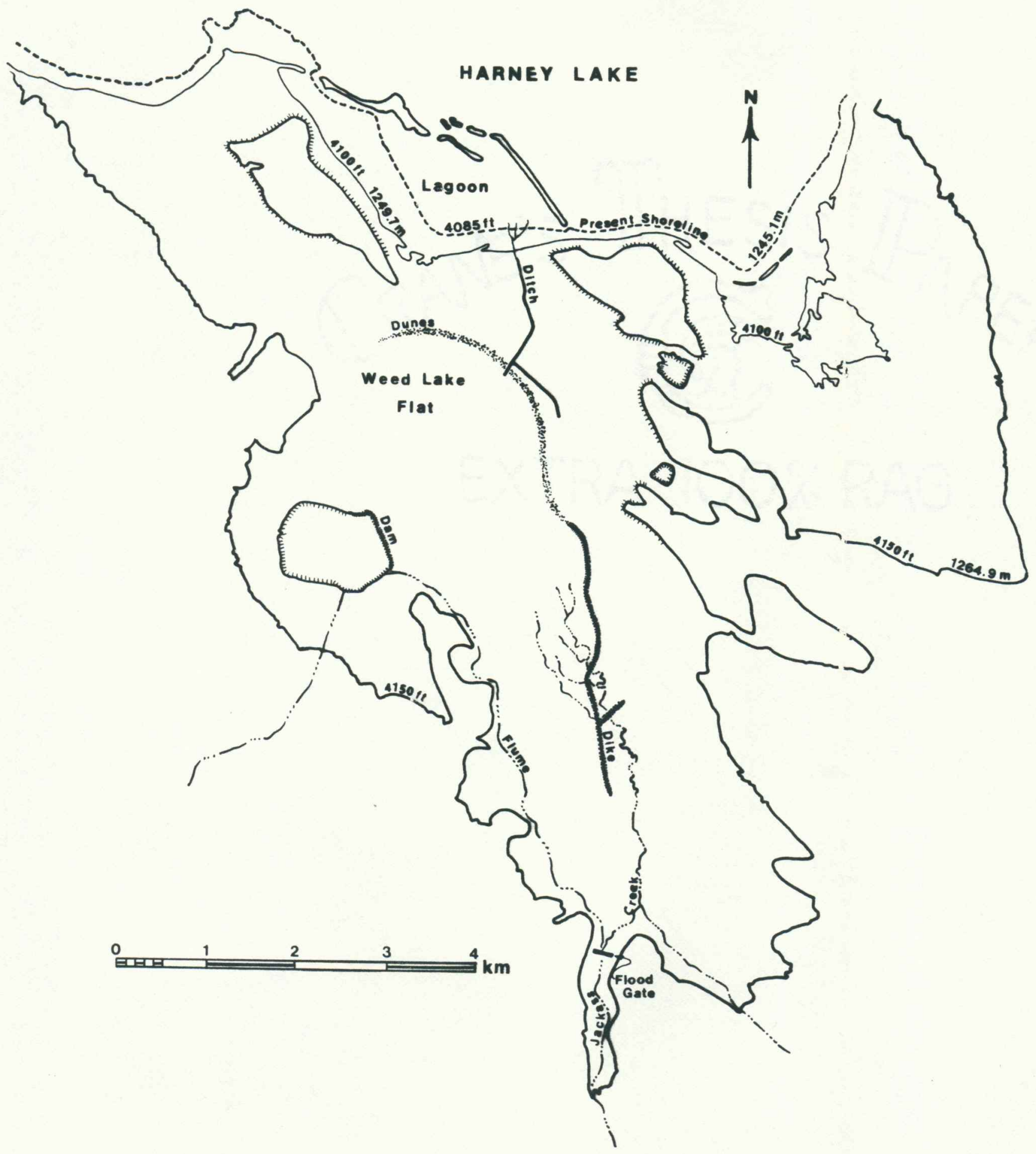

Figure 8. Map of Pleistocene Jackass Bay of Pluvial Lake Malheur with present topographic features superimposed. 
(Figure 8). By 8700 years ago the two lakes again temporarily became one when Pluvial Lake Malheur rose to its overflow level.

The area occupied by Weed Lake is now planted in hay and alfalfa. The soil is underlaid by impermeable clays so that in the recent past when rainfall did come the area became a shallow water playa. One landholder, Mr. Pat Church, informed me that the ditch was dug shortly after the turn of the 20th century to drain surface water from Weed Lake Flat. It has been widened in more recent times to better handle the flash floods resulting from the occasional cloudbursts that hit the area.

The upper (south) end of the area was likewise modified. Prior to this time Jackass Creek simply debouched onto the Flat. A dam and diversion ditch were dug to carry any normal winter flow of Jackass Creek into an artificial reservoir where it is held for summer irrigation. At the same time a long levee was constructed to divert any excess water through a flood gate onto the desert floor to the east of Weed Lake Flat. There it is picked up by an interceptor ditch and directed into the main drainage ditch where it flows to Harney Lake playa (Fig. 8).

The north end of Weed Lake Flat is surrounded by a ring of inactive dunes $3.7 \mathrm{~km}(2.3 \mathrm{mi})$ in length which have built up over an old shoreline. The levee ties into the east end of these dunes and extends this natural barrier an additional $2.3 \mathrm{~km}(1.4 \mathrm{mi})$, almost to the mouth of the canyon of Jackass Creek. The very south end of the ditch is cut through this ring of dunes which are now largely stabilized by vegetation. 
B. Field Work

\section{GEOMORPHOLOGY}

The starting point for all survey work was a convenient U.S. Geological Survey benchmark located about $600 \mathrm{~m}$ from the site (Figure 8 ). From this point a more convenient working datum was established about $200 \mathrm{~m}$ south of the location of the artifact find. Finally an accurately located and leveled site datum was placed, as was an arbitrary point in the ditch from which to begin stratigraphic mapping. (See Appendix for surveying details.) A series of 66 stakes was then set in the ditch over a distance of $1300 \mathrm{~m}$. In general, these were $25 \mathrm{~m}$ apart although in one section they were later reset $10 \mathrm{~m}$ apart and in another $3 \mathrm{~m}$ apart to enable increased mapping resolution.

The elevation of the top of each stake was precisely measured as was the distance between them. It was then possible, using a line level with a staff placed on the stake, to closely estimate the elevations of any observed strata or other features. In this way 91 accurate stratigraphic vertical sections were measured for the portion of the ditch that was mapped. Only a small section on private land at the south end was not covered and there appeared to be little of interest in that portion.

Figure 9 is a plan view showing the survey lines in the ditch compared with the north-south baseline. The ditch does not follow a straight line so some error will be present in the stratigraphic maps due to this lack of linearity. 
Figures 10 and 11 present stratigraphic vertical sections of the ditch with a vertical exaggeration of 50x. Four portions of these figures which display old shorelines have been redrawn as Figures 12 to 15 . These are at larger scale and are reduced to $10 \mathrm{x}$ vertical exaggeration. They are presented and discussed in the following chapter. (1)

\section{ARCHAEOLOGY}

In the surmer of 1976, Dr. Thomas M. Newman of Portland State University excavated a $2 \times 2 \mathrm{~m}$ test pit centered about $7 \mathrm{~m}$ northwest of the artifact find location. No cultural material was found. The next year, when most of the field work for this project was done, I placed two more similarly sized pits somewhat closer to the find location (Figure 16). Again, both were sterile of cultural material. Each pit went approximately $1 \mathrm{~m}$ below the original surface level and well into the underlying gravel layer.

Even though I had originally intended a much more extensive samp ling of the area, there did not seem to be much point to continuing. Time and available field help were severely limited. Two other facts were also powerful deterrents to further digging. One was the questionable context of the original point find. The other bore even more weight. As will be discussed in the next chapter, the silt layer where the artifacts were found was clearly deposited by fast-running flood waters. Whether or not the artifacts had been in situ, the chance of flood redeposition seemed high.

(1) Since Figs. 9-15 will be cited repeatedly, for convenience of reference they are located immediately prior to the Appendix, beginning on p. 158. 


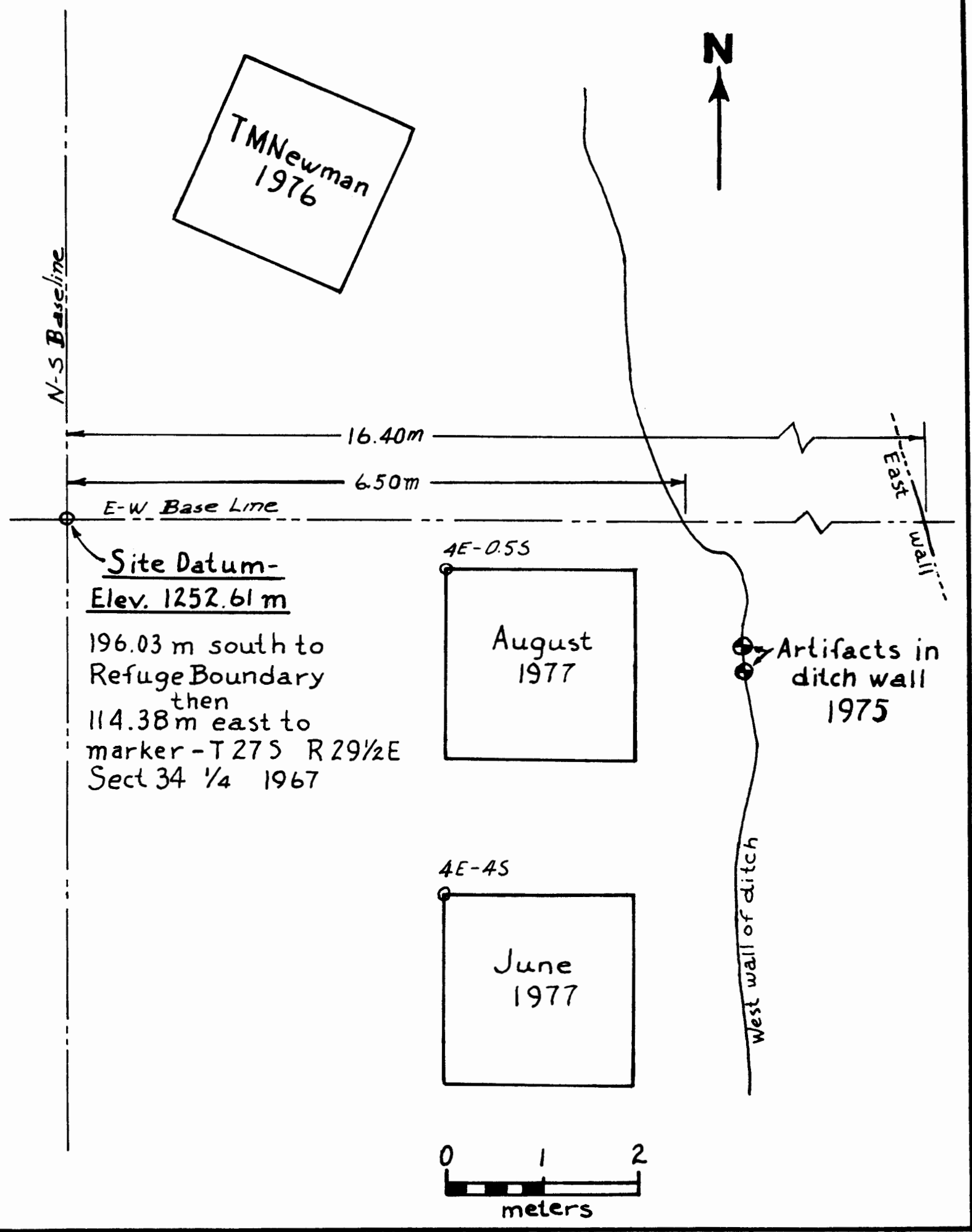

Figure 16. Test excavation locations 
Many hours were spent by many people in further examination of the ditch itself for in situ artifacts. The only artifacts found in 1977 were either in the gravel on the ditch floor, and therefore totally lacking context and value, or were flakes plastered onto the ditch walls. These flakes almost certainly had been transported by flowing mud from the surface above. The following year two artifacts, newly exposed by winter rains, were found in undoubted ditch wall context. They will be treated in detail later.

An archaeological survey was made of the area within a 1.5 to $2 \mathrm{~km}$ radius of the site. Two sites were known from the survey of the Malheur National Wildlife Refuge (MNWR 143 and 147). Four additional sites were located and reported. With one exception, all were at an elevation of about $1256 \mathrm{~m}(4120 \mathrm{ft})$. Site $35 \mathrm{HA} 341$ was on what had formerly been a long spit of land extending into Pluvial Lake Malheur. Cultural debris was scattered over an area 20 to $40 \mathrm{~m}$ wide and in excess of $700 \mathrm{~m}$ long. This was dense for about $200 \mathrm{~m}$ on the lake end of the spit. Locations of these sites are noted on Figure 17. 


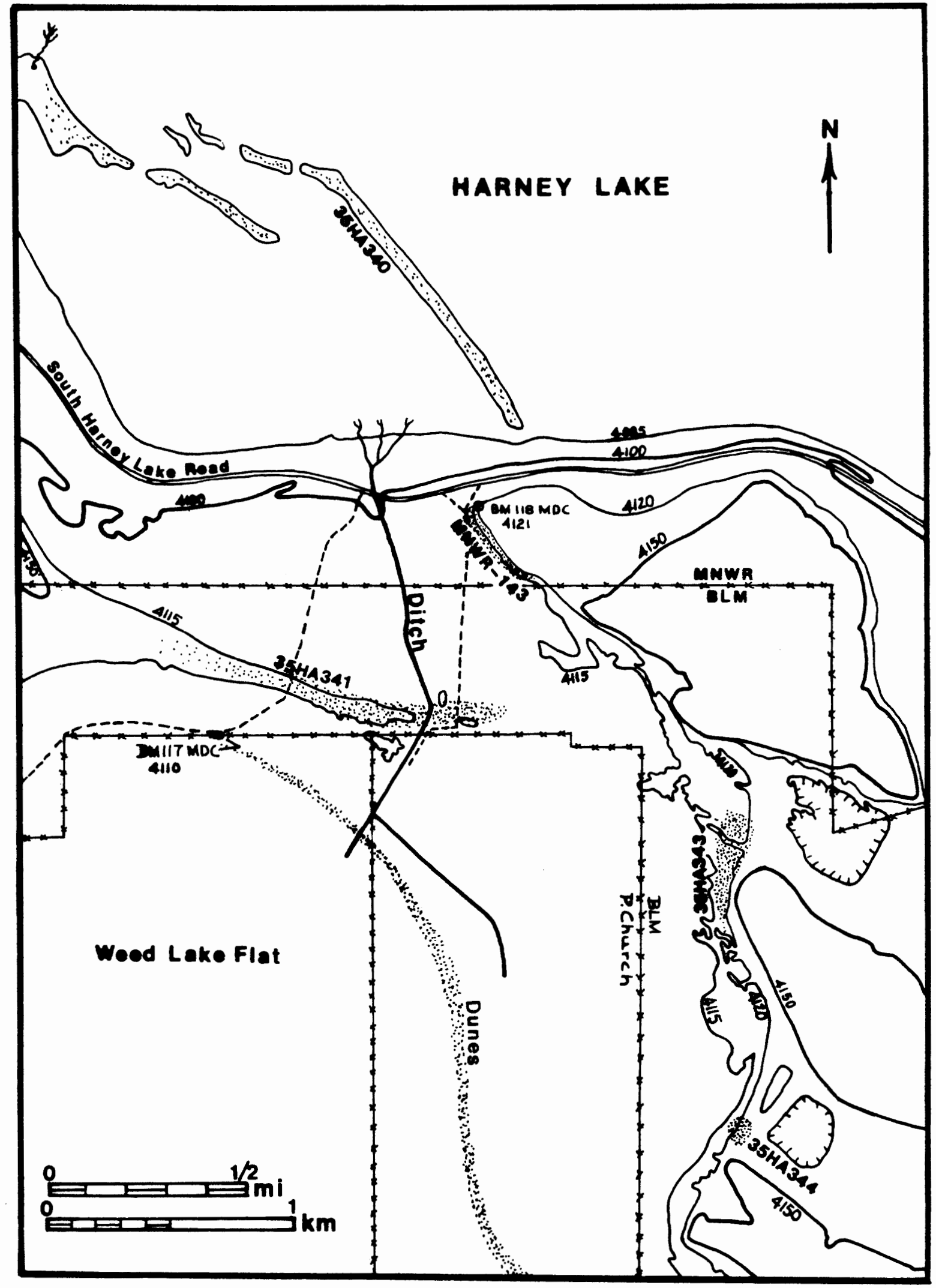

Figure 17. Archaeological site locations in study area. Site areas are stippled. Redrawn from Harney Lake 4NE, Oregon n.d. 


\section{ANALYSIS AND RESULTS}

In this section I will present and analyze the geomorphological, archaeological, faunal and chronological data obtained during the field study.

Gladfetter (1977) puts forward an elegant argument for the synergism that can accrue between a geomorphologist and archaeologist. He talks in generalities in the paper, but the insights he offers to the ways in which the geomorphologist can help the archaeologist interpret his site are hard to dismiss. It is important to note that the benefit can be mutual. Forbes (1973), for instance, made a minutely detailed study of the landforms created by the Pleistocene lake in the Fort Rock Basin of Oregon using archaeological data exclusively to date these features.

This interdependence can best be appreciated in the present study when one considers that it covers a time of changing landforms and changing resources. Quite probably there were times when observable change occurred within the lifetime of an individual; certainly within the time span covered by the oral history of the desert people. In this instance, the changing land must first be understood if we are to have insight into the change that took place in desert lifeways.

\section{GEOMORPHOLOGY}

\section{A. Abandoned Shorelines and Their Chronology}

The drainage ditch from Weed Lake Flat to Harney Lake provides a rare opportunity for geomorphic interpretation (Figure 18). It exposes buried lake floors and/or beach ridges associated with six stillstands of Pluvial Lake Malheur. Three of the beach structures have been dated by 


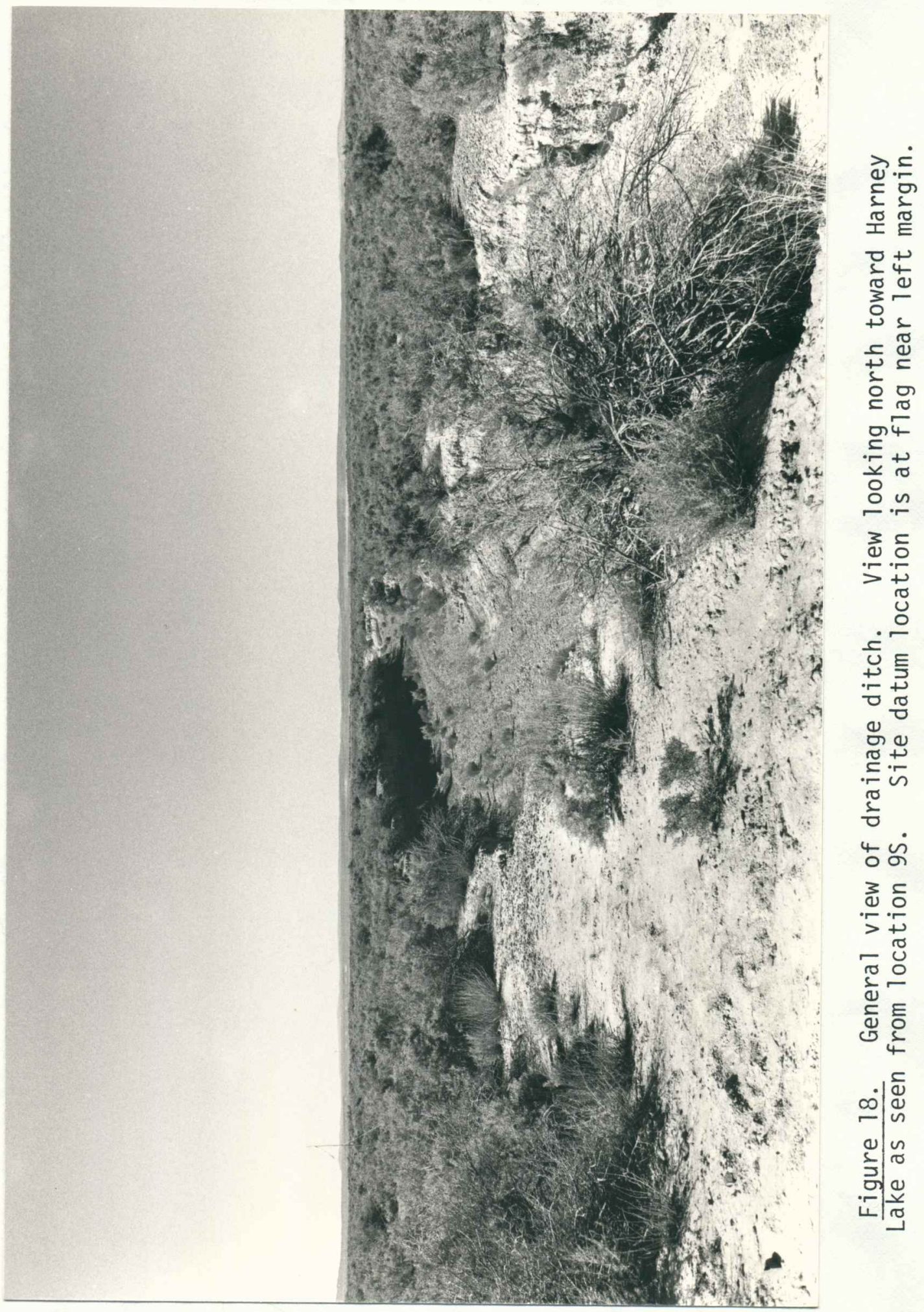


${ }^{14} \mathrm{C}$ determinations run on associated molluscan remains. Two more dates are in process. Only the youngest of the lake stillstands has thus far defied dating efforts.

Rather than consider these lake features chronologically, I will describe them in the order they would be seen by an observer walking south along the ditch from its mouth at Harney Lake. I will also show how features seen in the ditch have areal or regional representation, when this is possible. Figures 10 and 11 show the overall stratigraphic profile in a $50 x$ vertical exaggeration. Figures 12 to 15 show selected features at $10 x$ vertical exaggeration. Locations are derived from survey stake numbers which are, with a few exceptions, located $25 \mathrm{~m}$ apart.

Surface Beach Ridge: $1249-50 \mathrm{~m}$ Elevation. The first shoreline feature is seen at the Harney Lake entrance to the ditch. Here the ditch cuts through the youngest of the beach ridges (Figures 12 and 19). Elevation of the top of this feature is quite uniform, varying little more than $0.5 \mathrm{~m}$ above or below $1249.6 \mathrm{~m}(4099.7 \mathrm{ft})$. It is readily traceable for at least $10 \mathrm{~km}$ along the southern edge of Harney Lake (Figure 20). This is the single abandoned shoreline feature described previously by the geological writers who have worked in the basin.

Piper et al (1939) correlate this beach ridge with a shoreline structure found in the eastern part of the Basin. Near Malheur Gap the elevation was reported as $1252.0 \mathrm{~m}(4105 \mathrm{ft}), 1.5 \mathrm{~m}$ higher than at Harney Lake. They do not report whether the higher elevation in the eastern part of the Basin is a local or general phenomenon. A number of explanations could account for it. This is a tectonically active area and it could be due to minor crustal warping. It could also be due to isostatic rebound, 


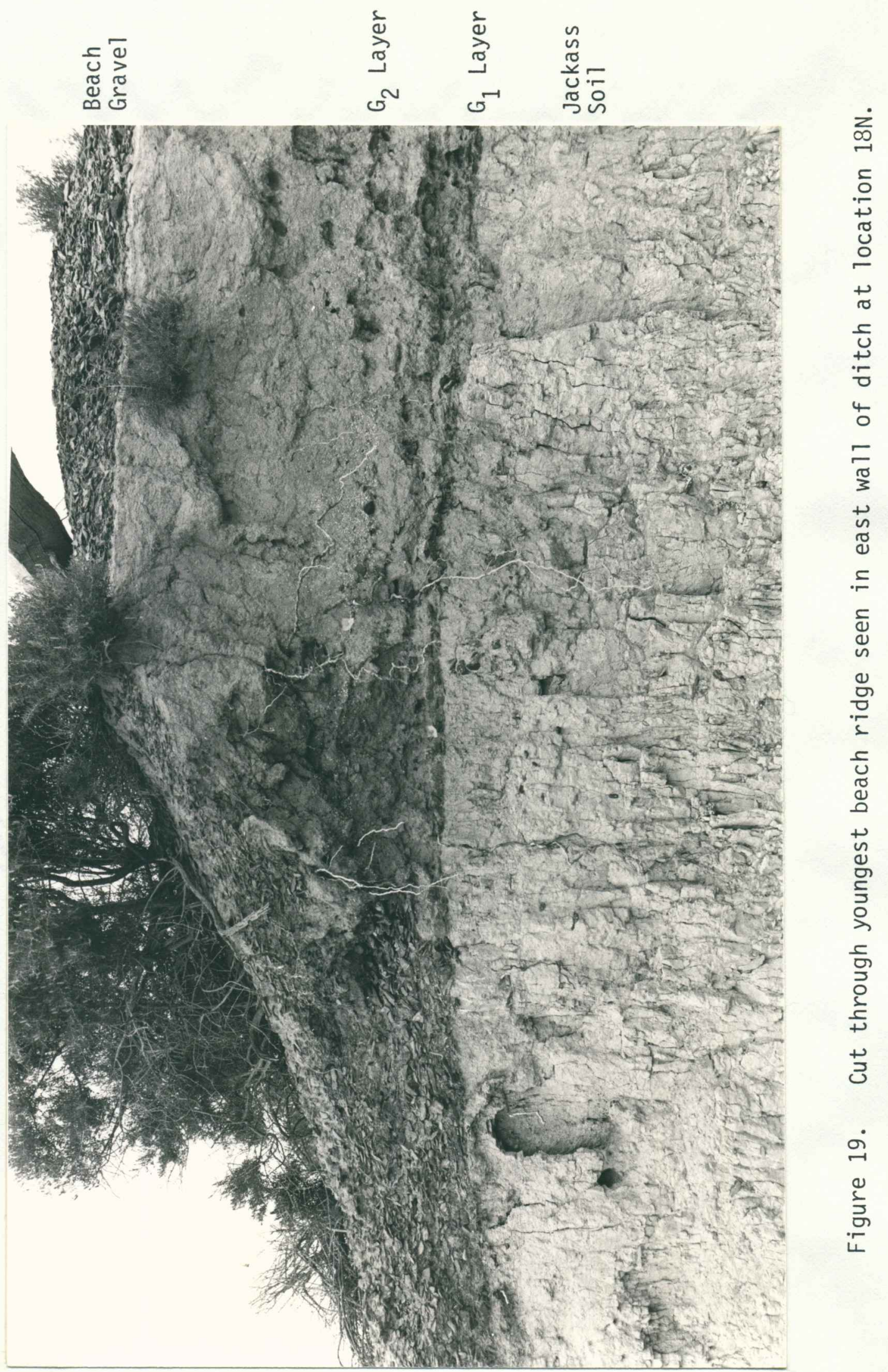




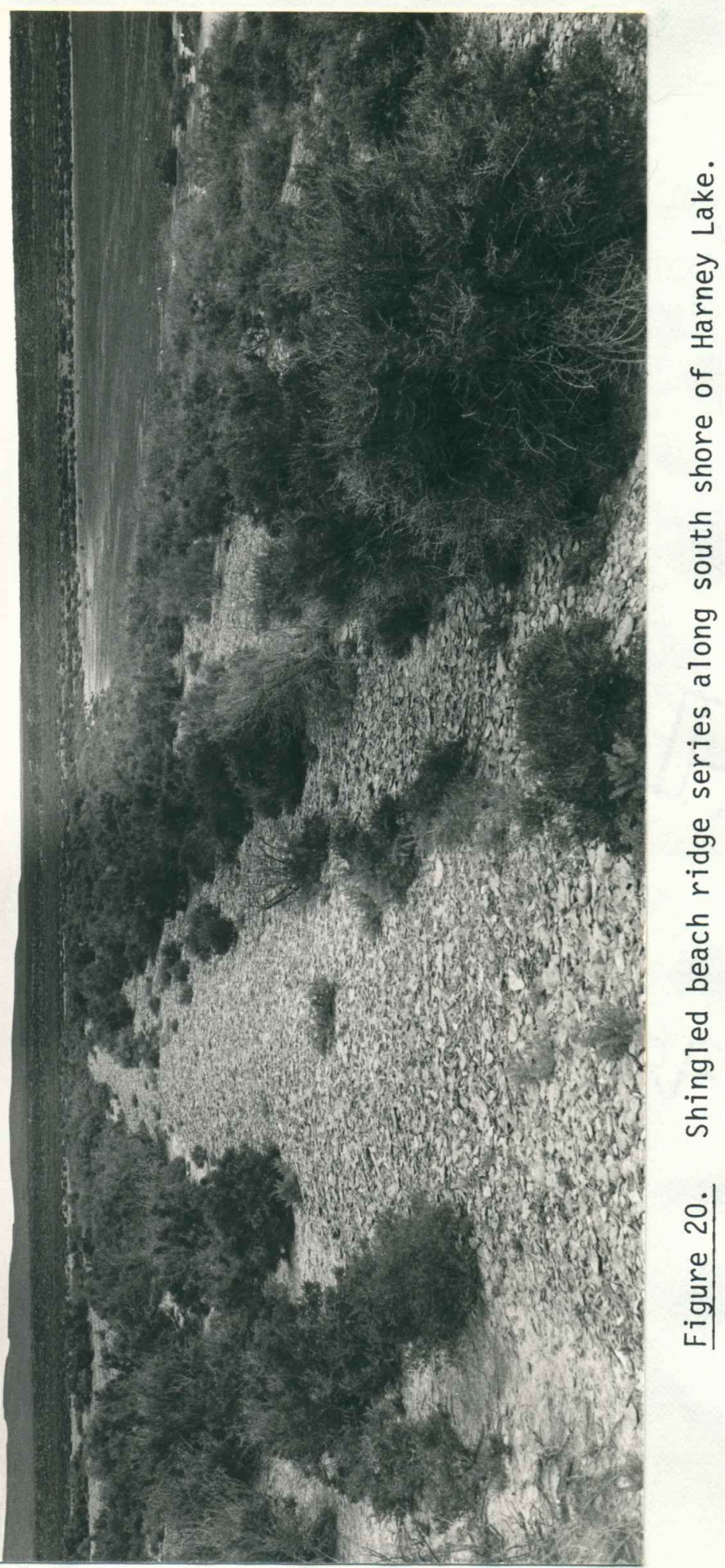


or to the effects of heavy localized wave action.

The beach ridge seen along the south edge of Harney Lake varies from gravel shingle to an earthen berm. In some locations there is but a single ridge present. In others, several ridges and/or short benches are in a tiered array. A profile about $250 \mathrm{~m}$ west of the ditch has a gently sloping surface from the playa, terminating in a short gravel terrace followed by a low gravel beach ridge. That, in turn, is followed by a wider and higher soil ridge crossing the desert floor. At the ditch mouth, there is only a single gravel ridge present. Three kilometers to the east, at least four and perhaps as many as six such shingled ridges can be seen in an area not more than $75 \mathrm{~m}$ wide (Figure 20).

The form of the ridges seems to be heavily dependent on the type of material available for their construction. West of the study area (Figure 7) there was little rock available for comminution by wave action. Here, simple earthen berms are the cormon beach ridge types. At the eastern edge of the study area, a rhyolite butte was an apparent source of rock for gravel. This gravel was carried by wave action at least $2.5 \mathrm{~km}$ east of the bed rock source to where it served as an abundant source of material for beach ridge building.

Beach ridge structures formed from the gravel seem to be more complex than those for which no gravel was available. All of the tiered ridges I observed were predominantly gravel structures. The only exceptions were composites where the highest ridge was an earthen berm, and the lower ridges were gravel. The few composites noted occurred in areas where the gravel supply was scanty.

Piper et al (1939:14) seem to imply that these tiered ridges may be 
the result of changes in lake level. A simpler answer seems more likely: the tiered shingled beach ridges have probably been created by individual storms or storm seasons rather than by any minor changes in lake level (Forbes 1973:185, Johnson 1965:440). Height of beach ridges is controlled by wave level which may easily range from 1 to 2 meters on lakes the size of Pluvial Lake Malheur (Johnson 1965:442). Wind driven ice packs can plow high gravel ridges well back from normal lakeshores (Rhue 1975:182 et seq.). Russe11 (1903b:30) recognized the effect of storms in controlling the height of shingled beach ridges. Johnson (1965) cites complex series of high and low shingled shoreline ridges created within a relatively few seasons.

Looking at these ridges one cannot help but be impressed by their geological recency. They have sharp and uneroded features and give the impression that the lake had retreated only a few years ago.

As stated earlier, there is good evidence for a general climatic shift to more arid conditions about 7500 years ago. Mehringer (1977) and others have noted a rebirth of some Great Basin lakes during a period of increased moisture between 6500 and 5500 B.P. There was a similar climatic amelioration with lake renewal "starting about 4000-3000 B.P. and ending before 2000 B.P." (Mehringer 1977:149). Morrison (1964) has found at least five cycles of shallow lakes alternating with desiccation at Fallon Lake during the last 4000 years. The present study has not been able to assign these youngest Harney Lake beach ridges to any of the foregoing moister periods. It is not safe to arbitrarily attribute them to a lake which suffered "Altithermal desiccation." Let it suffice to note that at least twice within the time of historic records, Malheur Lake 
has risen to within $1.4 \mathrm{~m}$ of the top of these beach ridges. Had the entire inner basin been filled to this level it would have contained a lake that could have easily created the late beach ridge series. It does not take a great stretch of the imagination to picture a minor climatic alteration that would again create a major lake lapping at these ancient shorelines.

As one looks at the cut through the youngest beach ridge series, it is apparent that the lake which created it has truncated a trio of older deposits (Figures 19 and 21. The lowest member of this trio is an unusual lacustrine deposit. It is a cemented columnar clay loam about $2 \mathrm{~m}$ thick. The upper $\underline{c} 50 \mathrm{~cm}$ is weathered and disperses in water with some difficulty. The lower portion of the soil is so cemented that it will disperse only if crushed. For field identification this was called the Jackass Soil from the name of the intermittent stream which waters the area. I propose this for its permanent name.

The flood through the ditch early in 1979 cut away portions of the floor as much as 1 to 1.5 meters in some places. A softer lacustrine silt was revealed under the Jackass Soil but this has not been mapped.

Lower and Upper Gravel Bands. The Jackass Soil contains surface erosional features and is disconformably covered by a monolayer of imbricated tabular gravel. Gravel orientation indicates that the flow direction of the water that carried this gravel was from south to north; i.e., from Jackass Creek toward Harney Lake. I have designated this as the $G_{1}$ gravel. This $G_{1}$ layer is covered by a thin $(5-30 \mathrm{~cm})$ layer of loam containing snails. The loam, in turn, is covered by another scantier and less distinctly imbricated gravel band, the $G_{2}$ gravel. In and above 

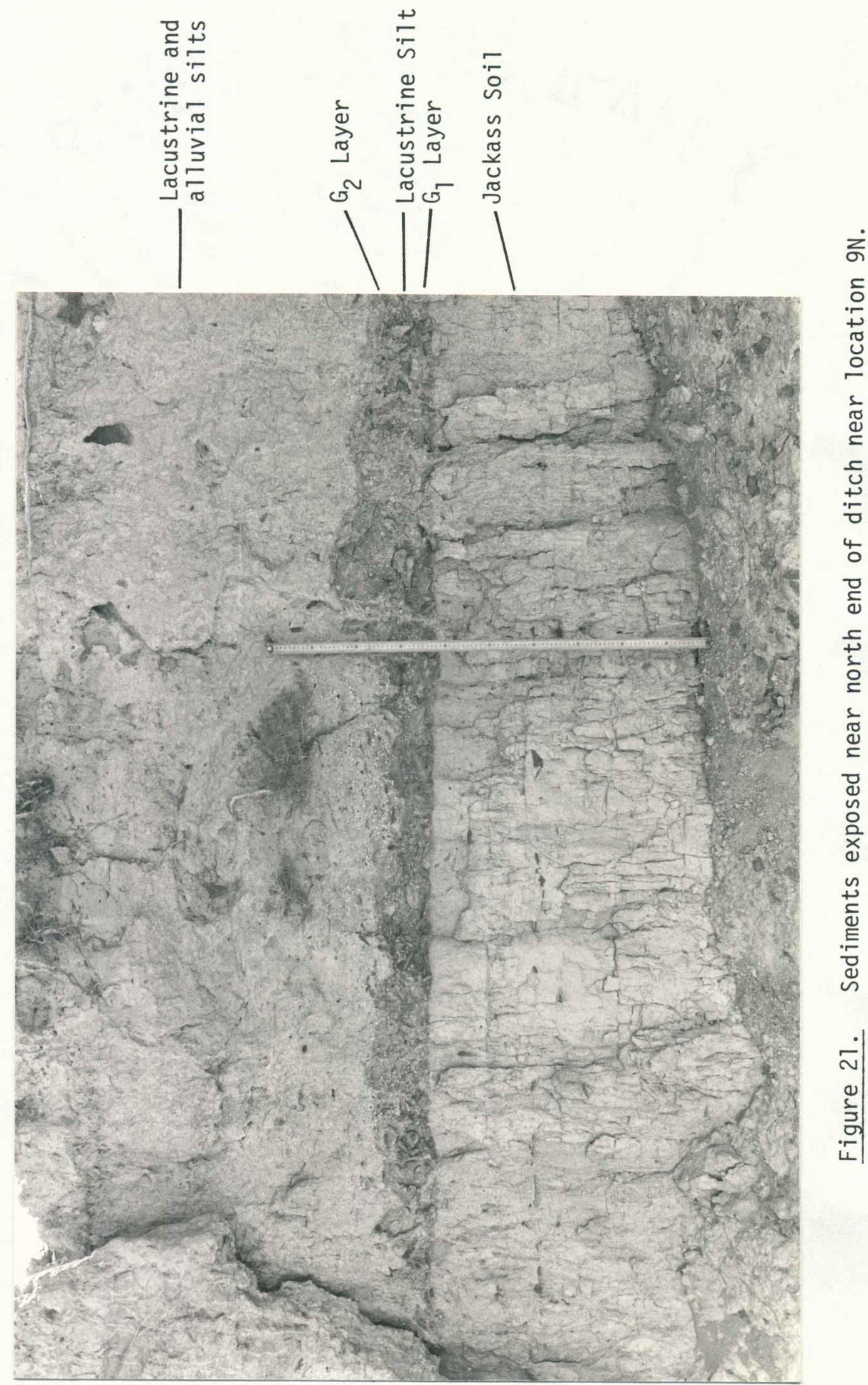

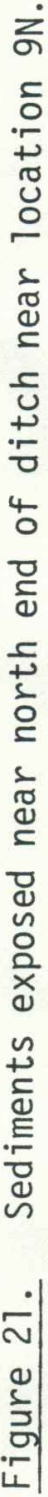


this band for perhaps $10 \mathrm{~cm}$ is an abundant deposit of small snails, predominantly of the species Fontelicella hendersoni. The shells have been ${ }^{14} \mathrm{C}$ dated to $9620 \pm 50$ B.P. (USGS-460B). These snails and the $G_{2}$ gravel form a continuous band and mark a lake floor which can be traced from the ditch mouth to a series of buried beach ridges about $700 \mathrm{~m}$ to the south.

Surface Deposits. The upper gravel is covered with a layer of soil that appears to be variable in both texture and depositional history. It seems to be lacustrine in nature near Harney Lake. This grades into flood plain alluvium to the south. Present vegetation is principally greasewood with other desert shrubs. Sage is infrequently present due to the high alkalinity. The original surface of this soil has probably been lost due to wind erosion. Texture analysis ${ }^{(1)}$ on samples of these soils gives the following results:

\section{TABLE IV}

TEXTURE ANALYSIS OF NORTH DITCH SOILS: LOCATION 16N

\begin{tabular}{cccccl}
\multicolumn{1}{c}{ Stratum } & pH & $\begin{array}{c}\text { Sand } \\
\%\end{array}$ & $\begin{array}{c}\text { Silt } \\
\%\end{array}$ & $\begin{array}{c}\text { Clay } \\
\%\end{array}$ & Classification \\
Lower (Jackass) & 10.3 & 26 & 44 & 30 & Clay loam \\
Middle & 10.6 & 52 & 31 & 17 & Loam \\
Upper & 9.9 & 52 & 21 & 27 & Sandy clay loam
\end{tabular}

32,000 B.P. Beach Ridge. A major gravel deposit rises out of the floor of the ditch $410 \mathrm{~m}$ south of the ditch mouth, beginning at location $\emptyset$ (Figures 13 and 22). This gravel arch is about $85 \mathrm{~m}$ wide and terminates in foreset beds just south of location 3S. These foreset beds

(1) All texture analyses reported in this paper were run by the Soils Laboratory of Weyerhaeuser Company. I am grateful to Dr. Eugene Steinbrenner and to Weyerhaeuser for this assistance. 


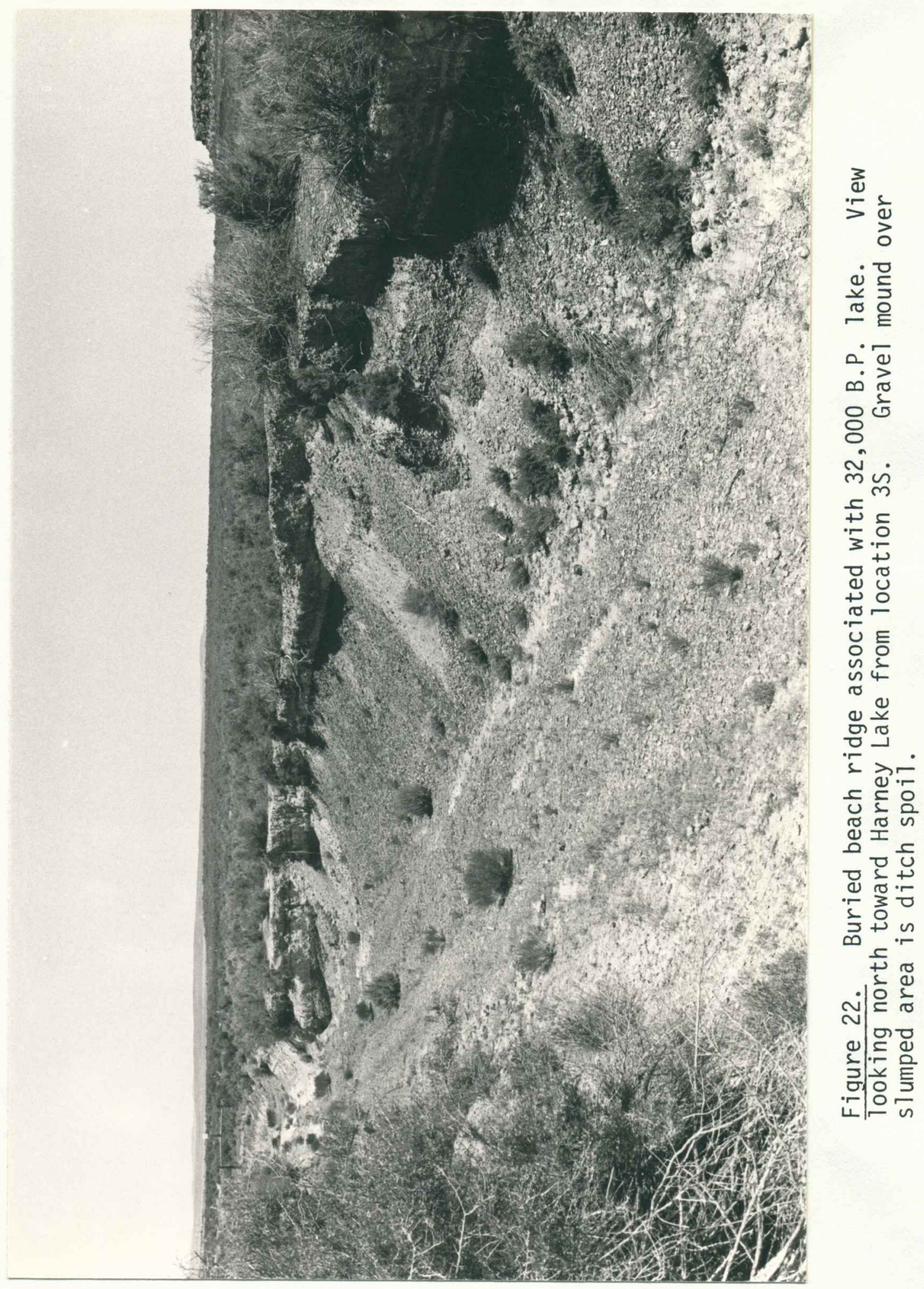


are key to its identification as a beach structure (Figure 23). Its massiveness, compared to the beach ridges seen on the surface, at first caused some difficulty in its identification. The illustrations and discussion in Sparks (1960) and Johnson (1965) were most helpful in resolving its nature.

A lens of snails in the lakeside face of the beach ridge gave the surprisingly early date of $32,040 \pm 400$ B.P. (USGS-459B). This marks it as the oldest of the beach structures found in the present study, although it is stratigraphically above two older lake floors to be described later. It is worth noting that 32,00 B.P. was a period of soil formation in the Bonneville and Lahontan Basins, an indication of relative dryness in those locations (Morrison 1965).

The stratigraphy overlying the 32,000 B.P. beach ridge was orginally unclear. It was obviously a critical area if the depositional geology of the lower part of the ditch was to be understood. Yet much of what needed to be seen was buried under slumpage from the ditch edge. In 1979 a new line of 16 stakes was set in the ditch floor between the location of original stakes $\emptyset$ and 4 . These were set $9.14 \mathrm{~m}(30 \mathrm{ft})$ apart at the ends of this range and $3.05 \mathrm{~m}$ (10 ft) apart beside the critical area over the crest of the beach ridge. The slumpage, where present, was excavated to undisturbed ditch wall and new elevations established.

Origin of the Jackass Soil. The Jackass Soil terminates on top of the 32,000 B.P. beach ridge. This raises questions for which there are presently no definite answers. The Jackass Soil represents a silted in lake. Since it pinches off on top of the beach ridge it could only have been deposited in a lake of higher surface elevation than the top of the 


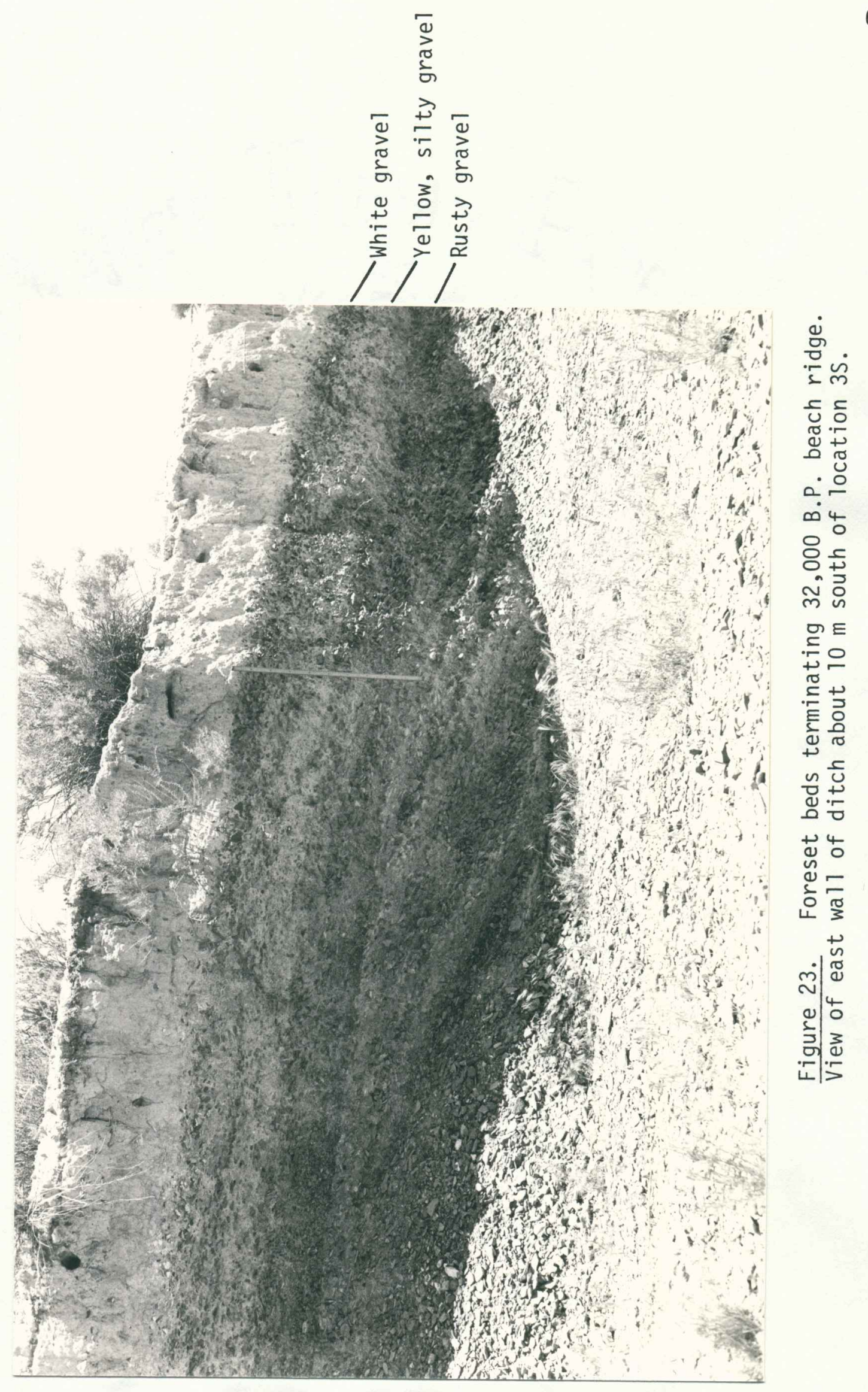


beach ridge. There are at least two pieces of evidence indicating that the Jackass Soil was deposited in fairly deep water. As a subjective observation, it does not appear to vary significantly in texture from top to bottom or from its first exposure at the ditch mouth to its final appearance on the lakeside face of the 32,000 B.P. beach ridge. Diatom speries found near the surface of the Jackass Soil are also typical of those in an open water lake (see p 120).

I propose one tentative explanation for the relationship between the surface of the Jackass Soil and the top of the 32,000 B.P. beach ridge. There is a notable hiatus in the record of the study area for the full pluvial period, believed to correspond to the latter stade of the Wisconsinan glaciation from about 25,000 B.P. to 14-12,000 B.P. (Mehringer 1977). The Jackass Soil may have been deposited in a higher lake of this time period and later eroded to its present surface contours. Further research is needed to resolve this problem.

Origin of the $G_{1}$ and $G_{2}$ Gravel Layers and Intermediate Layer. Three somewhat indistinctly separated gravel layers lie behind the 32,000 B.P. beach ridge, on the side away from Harney Lake. The lowest is the most massive, being about $1 \mathrm{~m}$ thick. This gravel is characterized by a rusty surface deposit. Above that is a yellow, very silty gravel band about $30 \mathrm{~cm}$ thick. Both of these gravels were deposited subsequent to creation of the beach ridge, apparently carried by water flowing toward the lake.

The yellow silty gravel pinches off on top of the 32,000 B.P. beach ridge and becomes the lower $\left(G_{1}\right.$ layer) of the two gravel monolayers, lying disconformably on the Jackass Soil. The imbrication in the monolayer reveals the south-to-north flow direction of the fast-running flood 
waters that created this deposit. This $G_{1}$ gravel filled a number of small transverse erosion channels on the surface of the Jackass Soil (Figure 24). The top of the beach ridge may have presented enough of an obstruction so that much of the gravel load was dropped behind the ridge. From this point the interpretation becomes much less certain. The fossil snails lie primarily on top of the later and thinner upper $G_{2}$ gravel monolayer. But lesser numbers are also found in the sandy layer between the two gravel bands. This sandy mid-layer also begins on top of the beach ridge and is interfingered between the two gravel bands. It is not found south of the beach ridge (Figure 13), and becomes thicker toward the lake.

Overlying the yellow silty gravel is a younger layer distinguished by a whitish coating of precipitated carbonate. This also pinches down to become the $G_{2}$ gravel monolayer at the top of the beach ridge. From that point it spreads over the sandy mid-layer much as the lower $G_{1}$ gravel layer spread over the Jackass Soil.

I propose the following hypothesis that would account for the existing structure. After the lower $G_{1}$ gravel layer was deposited on the eroded Jackass Soil, a rise in lake level occurred. The water over this gravel was shallow so that there was insufficient wave action to seriously disturb it. The wave action did have enough energy to carry in the sandy mid-layer, however. Note on Figure 10 that this is about $30 \mathrm{~cm}$ thick at the lake end of the ditch but wedges down in thickness toward the beach ridge.

The snails within the sandy mid-layer can be accounted for as follows. I propose that even though the overall trend of the lake was to 


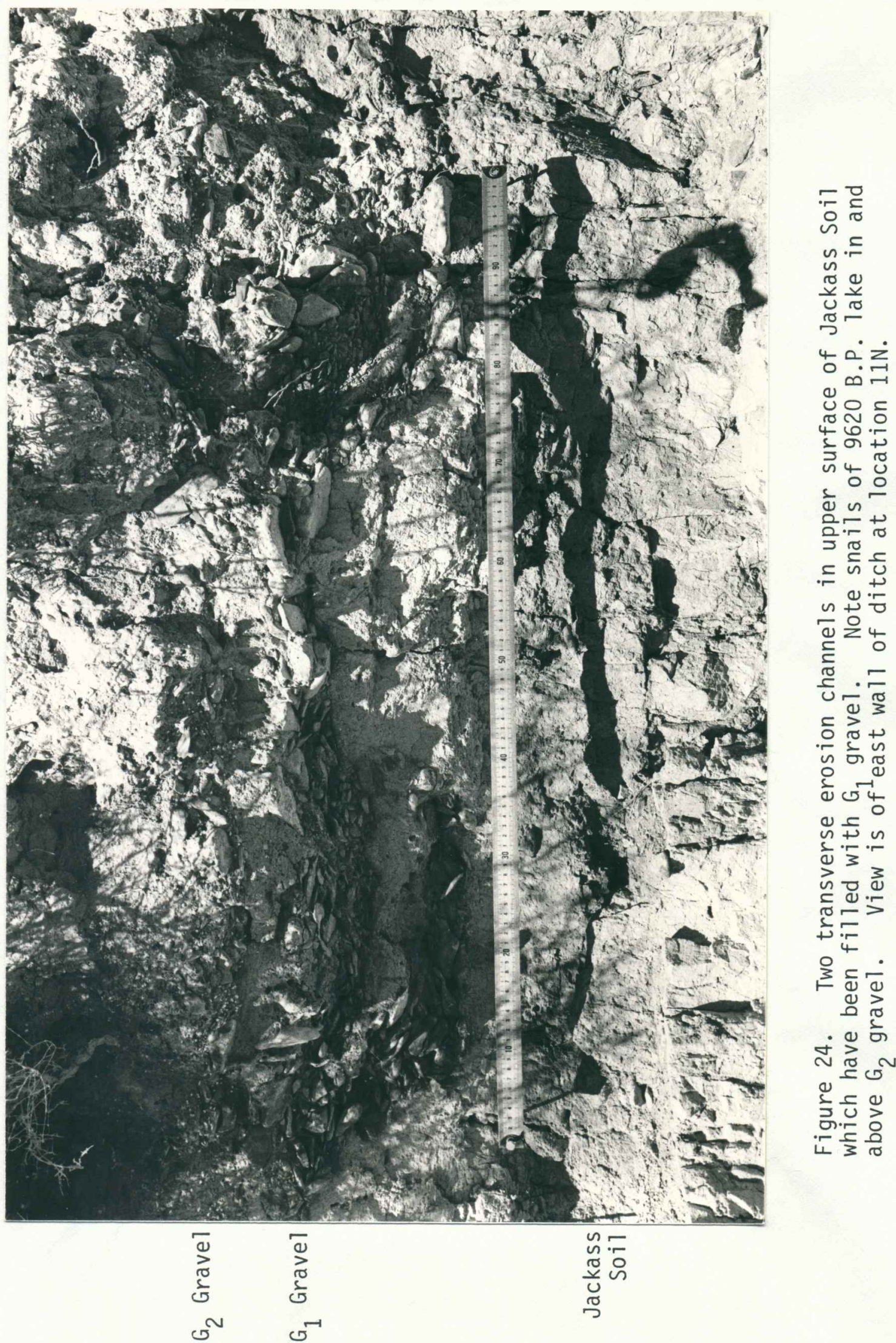


rise to a higher level, there were at first seasonal and then longer term periods of lake fluctuation. During the higher water periods, when the mid-layer was being carried in, snail colonies became established. Fontelicella hendersoni, the predominant species present, is a dweller on and immediately under the surface of silty bottoms. It requires permanent wel1-oxygenated waters ( $\mathrm{Dr}$. Dwight W. Taylor, personal communication). During the occasional years when the lake margin receded, these snails would die. Their shells would remain to be covered with more silt during the next high water period. The mid-layer was thus built up over a period of time with the snails accumulating with the silty sand.

During one of the emergent periods another sheeted flood carried down what has become the upper whitish gravel deposit behind the beach ridge. This too was in part transported over the now reduced obstruction presented by the beach ridge and was deposited over the sandy mid-layer as the $G_{2}$ gravel.

The area in which these deposits were made is broad and has very low topographic relief. Floodwaters would have minimum turbulence and scouring action while still retaining sufficient velocity to carry the gravel that became the $G_{1}$ and $G_{2}$ layers. The bulk of the smaller particle material in these floodwaters was carried in suspension into the lake after the gravel bedload had been dropped.

Shortly after deposition of the $G_{2}$ layer the lake continued its rise to a higher and more stable level. After this, the heavier snail population in and above the $G_{2}$ layer became established as a thin deposit of fresh silt was carried in over the $G_{2}$ gravel. As was mentioned earlier, this band of snails, dated to 9620 B.P, is traceable for about $700 \mathrm{~m}$ to a 
second series of buried beach ridges that mark the limit of this stillstand of Pluvial Lake Malheur.

The flash flood in 1979 did considerable scouring of the ditch walls and floor in the region of the 32,000 B.P. beach ridge, revealing sections of two earlier lake floors. These can be seen on Figures 10 and 13. The younger of these is indicated by a band of snails about $10 \mathrm{~cm}$ thick. The heavily predominant species in this band is Vorticifex effusus. There are also large mussels, Anodonta sp., present in this stratum, the only place where they were observed in the ditch. The population makeup here is similar to that found in the dated snail lens on the face of the 32,000 B.P. beach ridge. There is also a short exposure of foreset bedded snails near location $5 S$ stratigraphically beneath the above band of snails and separated by about $15 \mathrm{~cm}$ of sterile gravel (Figure 25).

The snails in these foreset beds are densely packed and have a significantly different species composition than those immediately above them. Fonticella hendersoni is the predominant snail. This is the same species of snail which is dominant again in the later stages of the lake; e.g., those that occupied the 9620 B.P. lake floor and 8680 B.P. terrace. No beachline features have been found which correlate with either of these older snail deposits. The U. S. Geological Survey has ${ }^{14} \mathrm{C}$ dating in process on both of these lakefloor deposits but results are not yet available.

Buried 9620 B.P. Beach Ridge. About $130 \mathrm{~m}$ south of the 32,000 B.P. beach ridge is another group of gravel arches (Figures 10 and 14). This series consists of three ridges with one broad and one shallow intermediate trough (Figure 26). The entire series is about $150 \mathrm{~m}$ wide and is 


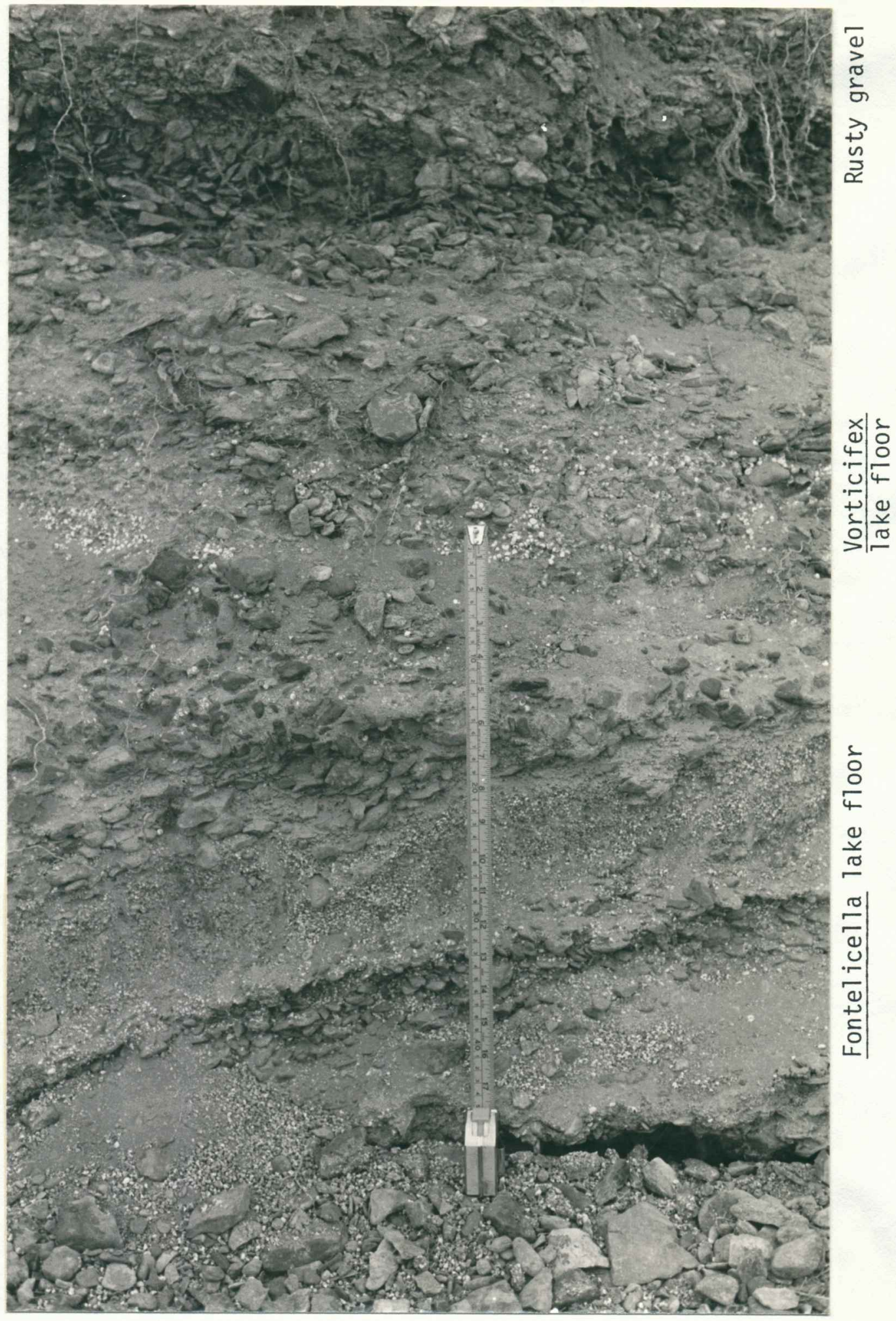

Figure 25. 01der lake floors stratigraphically under 32,000 B.P. beach ridge. View is at base of west wall of ditch about $10 \mathrm{~m}$ south of location $5 \mathrm{~S}$. 


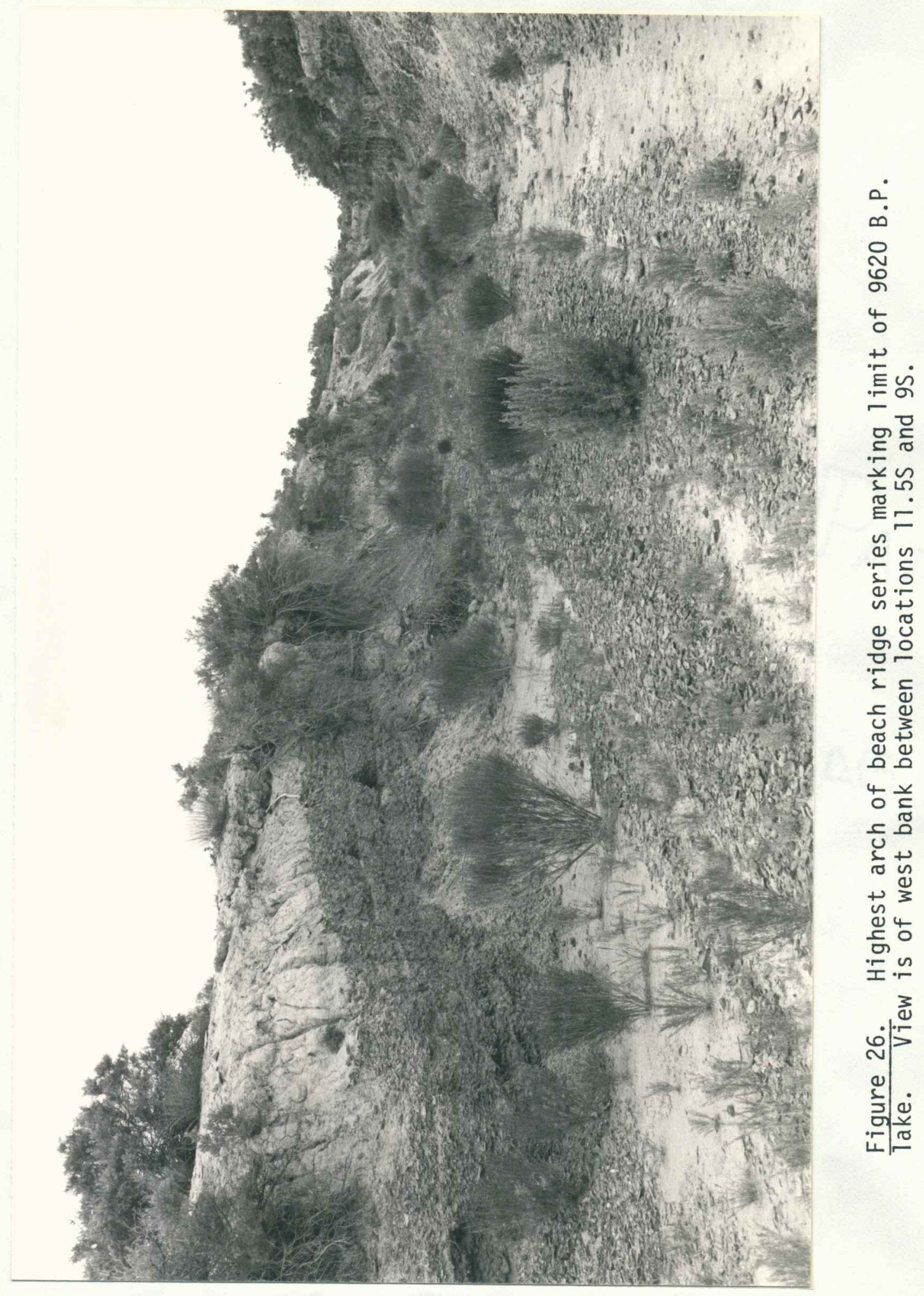


terminated by indistinct foreset beds between locations $13 \mathrm{~S}$ and $14 \mathrm{~S}$. The long band of snails marking the lake floor of this stillstand ends in the second (shallower) trough at about location 12S. These structures mark a beach ridge series that formed the margin of the 9620 B.P. lake.

The first and deeper trough apparently was a prime ecozone for the tiny Fontelicella hendersoni snails. In one area the shells are packed into a solid band up to $30 \mathrm{~cm}$ thick. Two thinner bands lie above these, separated by layers of sterile silt. Two different species of snails appear in the first trench. These are the much larger auger-shaped Lymnea of the palustrus group and the scroll or turbinate-shaped Planorbella subcrenata. Today these are found in well vegetated marshy areas which may seasonally dry up entirely. Their presence is fully in keeping with a shoreline having abundant vegetation and generally permanent water. The trough centered at location 95 may have been kept filled with water that spiashed over the adjacent ridge, probably an offshore bar, just north of $8 S$

As the snails thin out between 105 and 125 , Fonteliceila hendersoni becomes limited to discontinuous lenses. Lymnea is the last to disappear. This suggests that the trough between 115 and 125 was a lakeshore marsh occasionally separated from the main lake.

The area south of foreset beds between $13 S$ and $14 S$ is a complex mixture of gravel with interbedded silt lenses. I will not attempt an interpretation of the lower gravels in this exposure.

A lake existed in the Abert Basin, Oregon which is apparently coeval with the 9620 B.P. lake in the Harney Basin. Dr. Stephen Robinson (personal communication) reports a ${ }^{14} \mathrm{C}$ date of $9390 \pm 45$ B.P. (USGS-351) for a 
lake standing 20-22 $\mathrm{m}$ above the present level of Abert Lake. His date was run on a tufa-like carbonate crust on beach gravels found at this elevation.

Beach Ridge Correlative with 8680 B.P. Lake. A gravel monolayer originates at the top of the most southerly 9620 B.P. beach ridge, at about location 13S. This overlies a silt layer originating to the south that feathers out on top of this beach ridge. The gravel monolayer thickens markedly $130 \mathrm{~m}$ south of its point of origin. At location $19 \mathrm{~S}$ it expands into the third of the buried beach ridges in the ditch (Figures 11 and 15). The gravel has filled a series of nine small erosional crosstrenches in the underlying silt. These trenches may have been caused by a rilling action long prior to the time of the lake rise or possibly by wave action during the early stages of this phase. They are similar to those in the Jackass Soil illustrated in Figure 24.

This gravel mass between locations $19 \mathrm{~S}$ and $30 \mathrm{~S}$ is the most massive of the buried beach ridges exposed in the ditch, being fully $200 \mathrm{~m}$ wide and over $1.5 \mathrm{~m}$ in maximum thickness. The only possible source of the gravel was a location nearer Harney Lake, probably from the surface of some of the deposits just discussed. It was transported to the present location by vigorous wave action.

In the cross section exposed in the ditch the maximum elevation of this gravel deposit is $1253.3 \mathrm{~m}$. At this point it is overlaid by a mere $30 \mathrm{~cm}$ of silt. This gravel bar is manifested on the surface as a long, narrow ridge of land that originates at a butte on the western side of the silted-in estuary of Jackass Creek (Jackass Bay). It extends in a roughly east-west direction for almost $2 \mathrm{~km}$. Judging from present landforms, the 
eastern end of this ridge was never closed to contain the lake. This allowed the lake to flood the low lying land behind it. The ridge itself would have stood as a long, narrow peninsula into a shallow embayment. Archaeological considerations, discussed under site $35 \mathrm{HA} 41$, tend to support this interpretation (p 102 et seq.).

The high point on this ridge, measured on the extension of the north-south survey baseline, was $1254.7 \mathrm{~m}(4116.5 \mathrm{ft})$ at a point about $150 \mathrm{~m}$ west of the ditch. A bit further west it rises to a maximum elevation of $1256.0 \mathrm{~m}(4121 \mathrm{ft})$. These elevations are of great importance in considering the age of this beach ridge and the nature of the lake that formed it. They are also important to the question raised much earlier, in the discussion of the geological background, as to whether the Basiri has drained through either of the two outlet gaps.

Two other structures in the area are presumed to be temporally corrlative with this beach ridge, based on their equivalent elevations. All of them are at or slightly above the elevation of the present hydrographic divide of the Harney Basin in Malheur Gap. The first of these structures is a series of beach ridges in the form of earthen berms. These cross another large former embayment of Pluvial Lake Malheur at a location about $3.5 \mathrm{~km}$ west of the ditch along the approximate line between

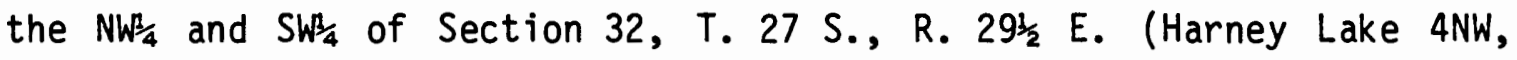
Oregon n.d.). The other structures are wave-cut terraces found in at least two locations in the inner basin.

The best example of a wave cut terrace is seen along the north edge and southwesterly oriented face of a butte located in the SE $\frac{1}{4}$ of Sec-

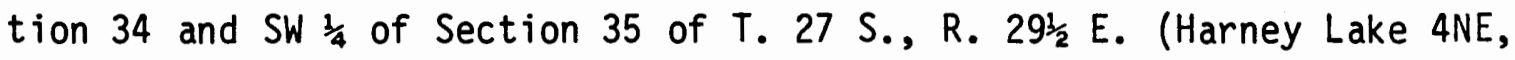


Oregon n.d.). This butte forms the eastern entrance into Jackass Bay (Figure 8). A photograph of this terrace taken from a location on Harney Lake playa is shown in Figure 27. The terrace elevation averages about $1255 \mathrm{~m}(4117.5 \mathrm{ft})$. A smaller terrace at the same elevation is located on the northwest face of a small butte in the SW $\frac{1}{4}$ of Section 35, T. 26 S. South of Malheur Lake, R.31 E. South of Malheur Lake (Lawen, Oregon 1959) (Figure 28). This terrace is only $1 \mathrm{~km}$ west of Malheur National Wildlife Refuge Headquarters.

It is surprising that these terraces were not recognized by earlier geologists who worked in the basin. Once seen they are almost unmistakable. An abundant deposit of snails is found just below the surface of the terrace facing into Jackass Bay. These snails are found in situ at elevations as high as $1255.1 \mathrm{~m}(4117.7 \mathrm{ft})$. This seems to be virtually indisputable evidence that these are indeed wave cut terraces and not some landform having a similar appearance.

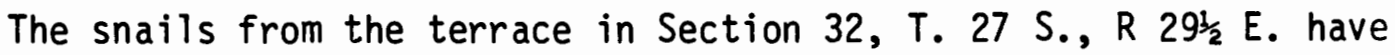
been ${ }^{14} \mathrm{C}$ dated at $8680 \pm 55$ B.P. (USGS-461B). This date is surprisingly late since it represents the highest observed lacustrine feature in the Basin. The elevation of the terraces indicates an overflowing Basin with drainage into the South Fork of the Malheur River. Elevation of the hydrographic divide in Malheur Gap is given in Piper et al (1939:18) as $4114 \mathrm{ft}(1253.9 \mathrm{~m})$. My own survey, starting at a U.S.G.S. elevation benchmark, confirms this figure. There is presently some silt accumulation of unknown depth in the abandoned streambed so the actual height of the divide will be slightly lower.

Equivalent terraces or beachline features were not found on the 


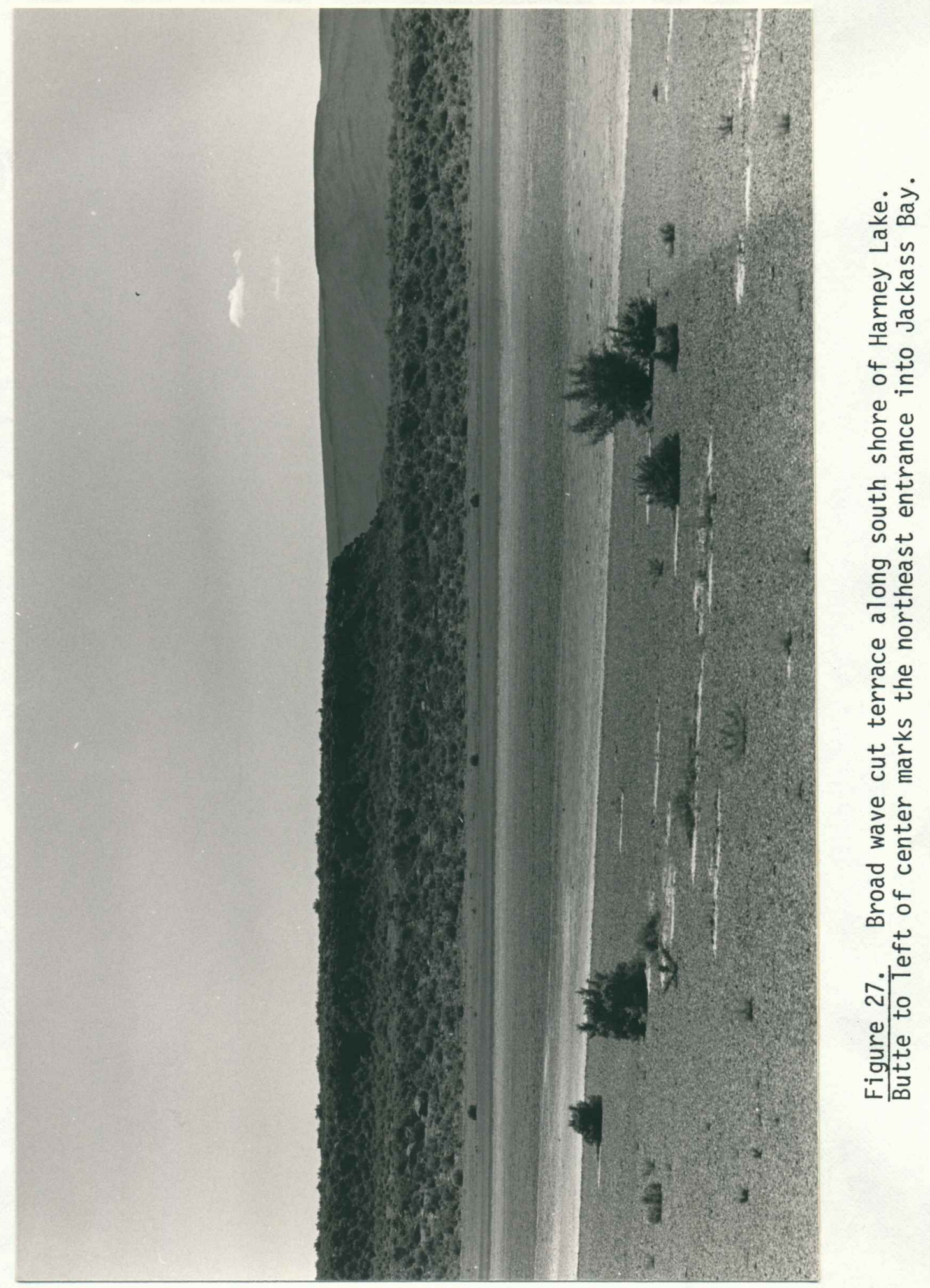




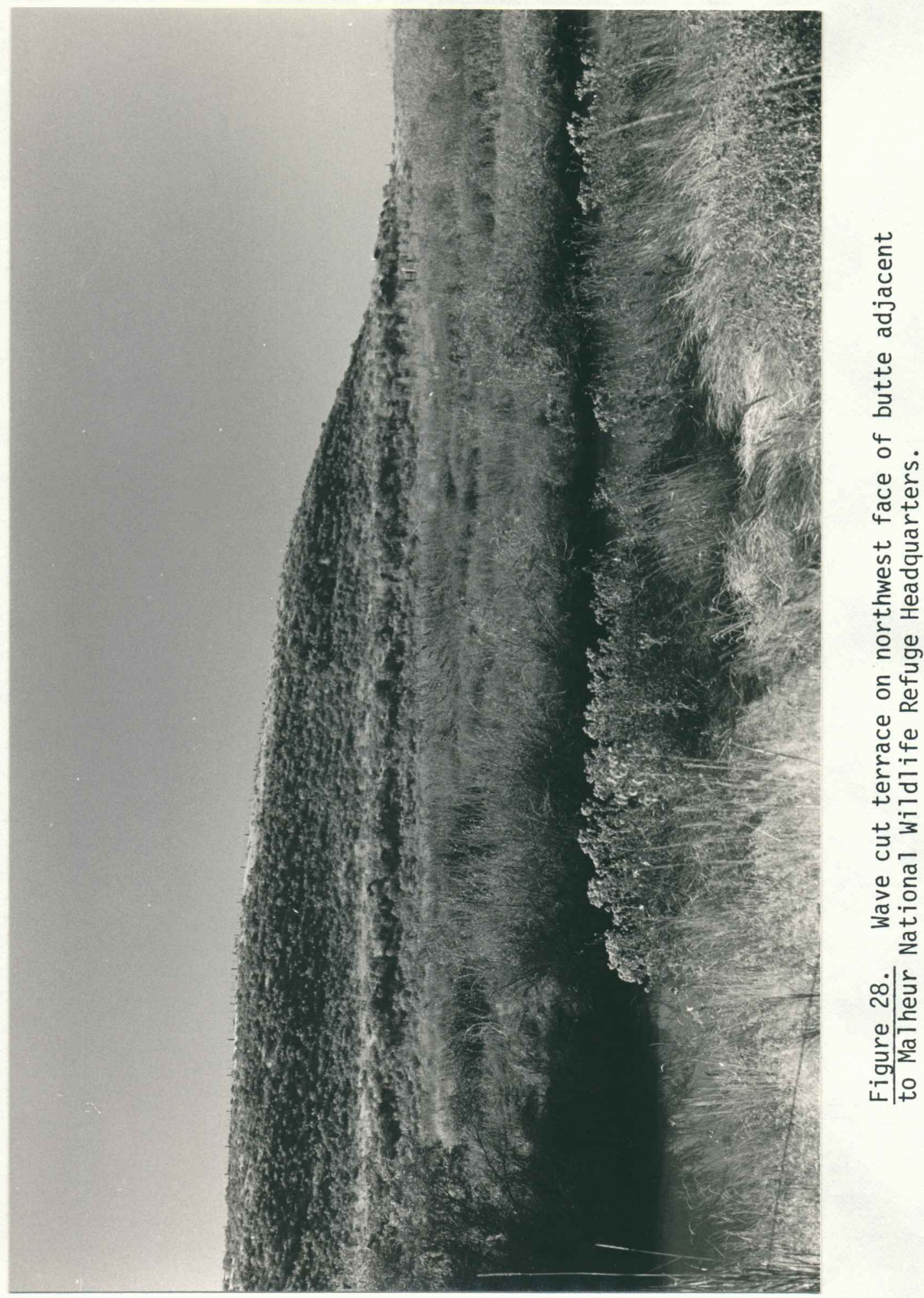


north shore of Harney Lake. This fact leads to the conclusion that prevalent high winds 8700 years ago were northwesterlies to northerlies. Such an observation is fully in accord with the conclusions drawn by Forbes (1973) for the Fort Rock Basin. Storm winds today that bring rain are primarily from the southwest. During the spring and summer very high winds unaccompanied by rain are common. These tend to be westerlies to northwesterlies. It seems hazardous to guess at the season(s) in the past during which high winds provided the wave energy to cut the terraces and build the berms and beach ridges or to associate such winds with the rainy season.

The question as to whether Pluvial Lake Malheur ever drained through Malheur Gap after the occurrence of the Voltage Lava flows has been solidly answered. It did, and it did so as late as about 8700 years ago, perhaps for some considerable period of time. The terrace on the Harney Lake exposure of the butte at the northeast entrance to Jackass Bay is as much as $100 \mathrm{~m}$ wide in places. This amount of cutting into rhyolite bedrock did not occur overnight and it indicates a relatively long stillstand. The canyon cut into the hard Voltage basalt in Malheur Gap is firm evidence that a stream of some magnitude once poured out of the Basin by this route (Figure 29 ).

It is equally clear that most, if not all of the Voltage lava was in place by 32,000 B.P. in order to contain the lake whose beach ridge crests at $1251 \mathrm{~m}$. This early lake may well have also been at overflow level as might the lake dated at 9620 B.P. Either tectonic adjustment (more likely) or a final veneer of basalt over the Voltage Lava (less likely) could have raised the outlet by 3 meters to its present elevation between 


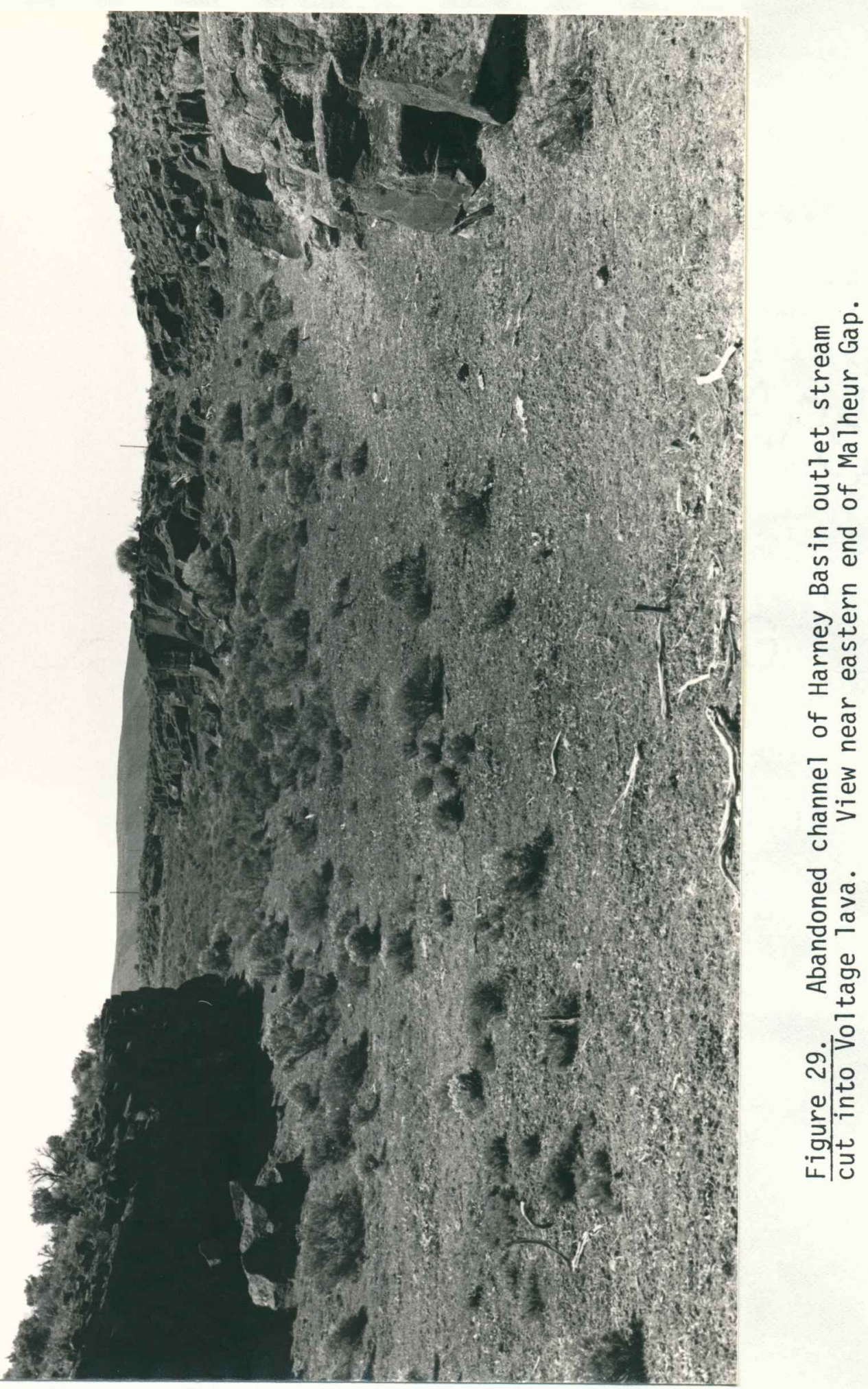


32,000 and 9600 years ago.

No geologic record has been found of a lake in the Basin during the height of the last pluvial period, presumed to be correlative with the maximum phase of the Wisconsinan glaciation between about 25,000 and 12,000 B.P. It seems safe to assume that much of the stream cutting into the Voltage basalt took place during this period. This would thus have been a preexisting streambed used and perhaps deepened by the later lakes but not primarily cut by their overflow water.

I also see a second question as resolved. The Voltage Lava did not divert the lake outlet to Crane Gap. This outlet has not drained the Bas in within the time period considered in this report. Crane Gap has a present hydrographic divide between 1262 and $1268 \mathrm{~m}(1240$ and $1260 \mathrm{ft})$, about 20 meters higher than Malheur Gap. There is no deposit of alluvium in Crane Gap as there is in Malheur Gap (Piper et al 1939), nor is there an out let channel to indicate a stream of consequence. The idea of out let diversion to Crane Gap may have originated with a misreading of Piper et al $(1939: 18)$ by Baldwin $(1964: 120)$. Piper and his associates made no such statement. This error has been perpetuated into the later literature (e.g., Deubbert 1969).

I am not going to attempt detailed interpretation of the deposits exposed in the ditch behind the 8680 B.P. beach ridge. These appear to be largely lacustrine silts with some apparent flood plain alluvium interfingered into them at places. Some of this silt seems to have been dropped by waters ponded behind the beach ridge. The only prominent snails are Lymnea of the palustris group and Planorbella subcrenata. Both of these are marshland taxa. While an understanding of the depositional 
history of these sediments might help to sharpen the picture already presented, there is no indication that it would be changed.

The faunal data provided by the snails and the geomorphic data of the sediments have been complementary. Data on the archaeological studies, now to be presented, appear to support further the geomorphological conclusions already drawn.

B. Archaeology

Six sites located in the immediate study area (Figure 7) are also shown on a composite vertical aerial photograph (Figure 30). While these will be referred to by Oregon State Museum numbers in this report, names are easier to use in the field. Both designations are listed here:

$35 \mathrm{HA} 340$

$35 \mathrm{HA} 341$

$35 \mathrm{HA} 342$

$35 \mathrm{HA} 343$

35HA344

MNWR-143
Lagoon Islands Site

Fenceline Site

Ditch Site

South Beach Terrace Site

Lost Sweater Site

South Harney Lake Beach Ridge Site 
Figure 30. Vertical aerial photographs of study area showing archaeological site locations and other features.

On Overleaf 


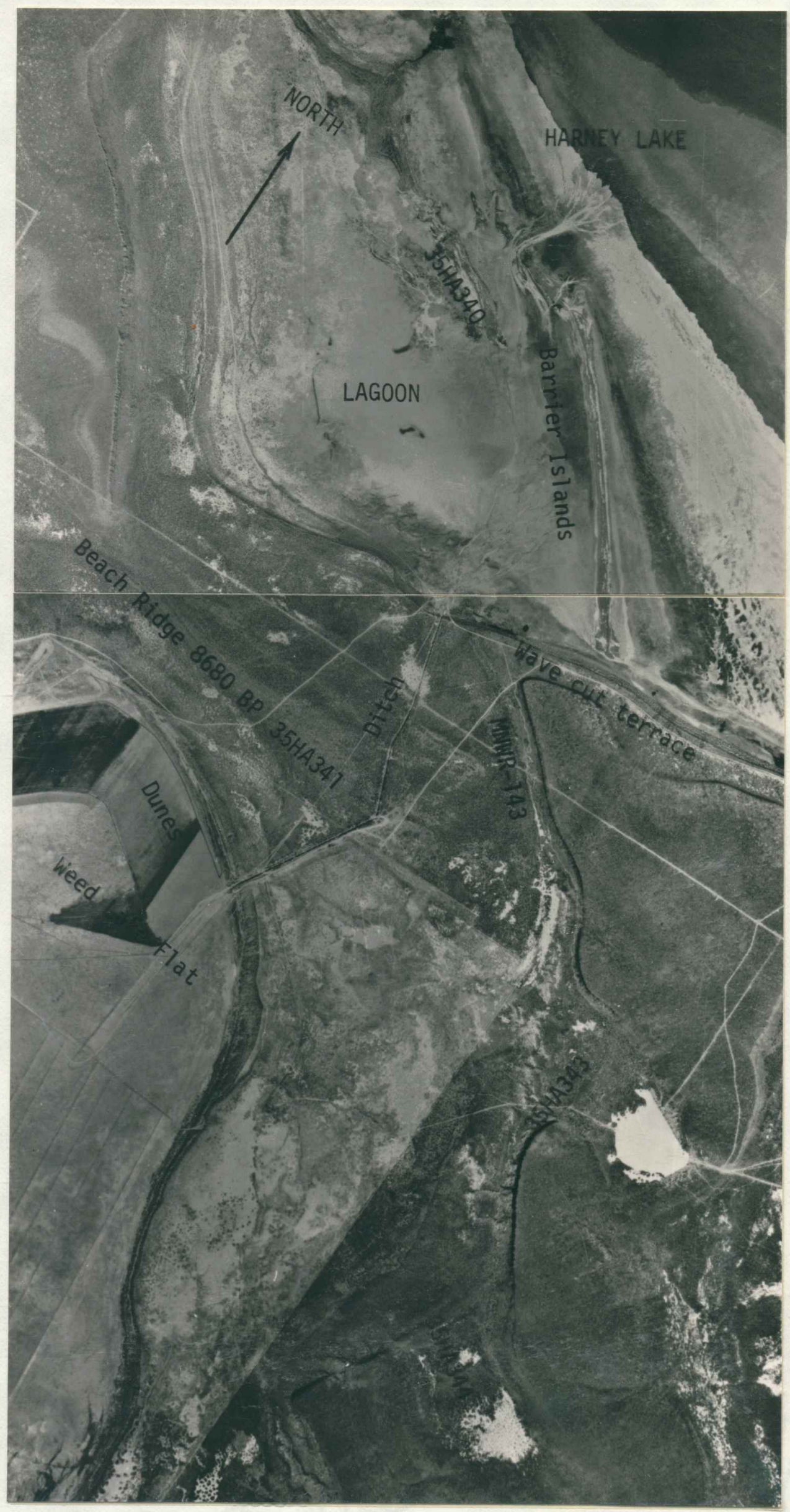




\section{SITE $35 \mathrm{HA3} 42$}

This site is centered on the location of the original Humboldt projectile point find in the drainage ditch. The circumstances of its discovery and the nature of the site were described in the previous section. In reality, this is more of a geomorphic than an archaeological site. It is the only site where any excavation was done.

The $2 \times 2 \mathrm{~m}$ test excavation by T. M. Newman in 1976 was an initial attempt to determine whether the original artifacts were part of a larger buried site. My 1977 test excavations had a twofold purpose. One was to look for additional artifacts in accordance with Newman's goal. A second, and equally important purpose, was to try to explain the depositional history of the soil column in which the artifacts were found. This latter goal was derived from an initial geomorphic interpretation that subsequently was found to be incorrect.

Originally, a layer of organic residue about $30 \mathrm{~cm}$ below the surface appeared to be a peat deposit. This was thought to mark a younger lake floor than the one immediately below the artifacts. It also appeared to be a means of assigning the artifacts within a radiocarbon age bracket. More careful examination showed this organic material to be the remains of recent desert vegetation buried under ditch excavation spoils (Figure 31). Nevertheless, the original purpose of determining depositional history was still valid. How or why the artifacts came to their ultimate resting place seemed to be knowledge fully as important as the fact of the ir presence. The first square dug in 1977 was 4E-4S (Figure 16). This particular location was chosen strictly on the basis of convenience since the surface had only a light veneer of ditch spoils. Closer to the 


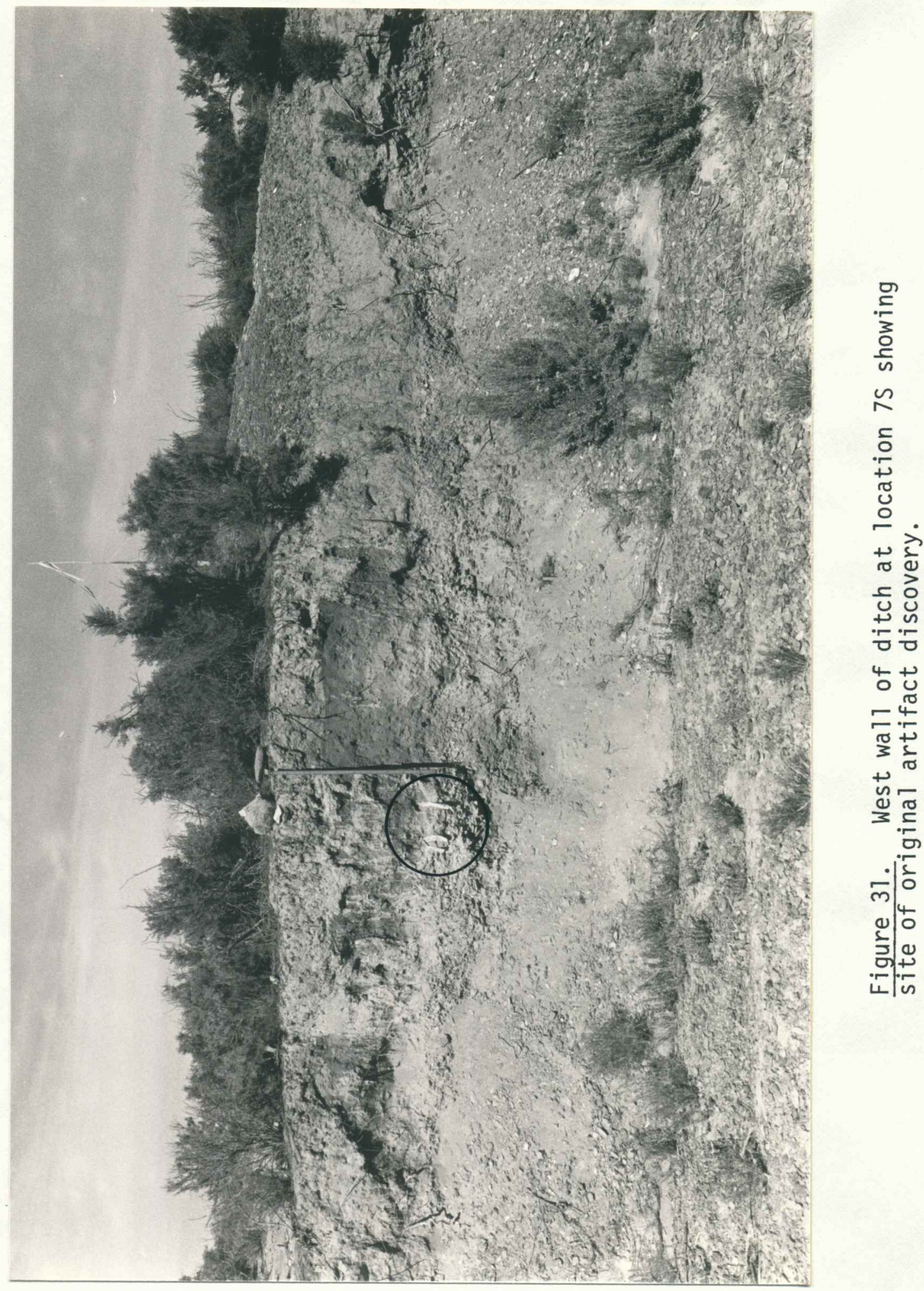


artifacts find there was a windrow of gravel approaching a meter in thickness overlying the original surface. As a final attempt, the second test square, $4 \mathrm{E}-0.5 \mathrm{~S}$, was sunk through this spoil rock at a location less than $1 \mathrm{~m}$ from the location of the artifact find.

Depending on the goal for each excavation unit, either two or three nested screens were used for examining fill. The two larger screens were made of hardware cloth nominally of $1 / 2 \mathrm{in}$. and $1 / 4 \mathrm{in}$. mesh $(1.27 \mathrm{~cm}$ and $0.64 \mathrm{~cm})$. The third screen, when used, was made of window screen with an actual opening of $1.14 \times 1.59 \mathrm{~mm}$. This was supported on $1 / 2 \mathrm{in}$. hardware cloth to prevent tearing.

For each square, the southwest quarter was triple screened and all rock on each screen was collected, weighed and examined for possible human alteration. This quarter of square $4 E-4 S$ was excavated in arbitrary $5 \mathrm{~cm}$ levels. The levels were increased to $10 \mathrm{~cm}$ in square $4 \mathrm{E}-0.5 \mathrm{~S}$, since the information being obtained did not seem to require the higher resolution. The other three quarters of each square were simply shoveled onto the two larger screens without any attempt at level control. A $10 \times 10 \mathrm{~cm}$ soil column was taken from the east wall of the northeast quarter of square 4E-4S. Again, all rock recovered was carefully examined for any indication of human presence. Nothing was found to indicate cultural modification. The soil overlying the lake floor gravel deposit was so solidly cemented by caliche that it was almost impossible to dig without first breaking it up with a geologist's pick. Each square was excavated into the top of the gravel layer.

The depositional history of the soil above the lake bottom gravel was not readily apparent from looking at the cut in the ditch wall. I 
first assumed this to be lacustrine in nature due to the presence throughout of occasional snail shells. These were the same as the predominant species abundant on and just above the surface of the grave1. It was this band of snails, more than anything else, that marked the surface as an old lake floor. Soil texture analyses and the size, weight and location of gravel in the soil indicate the assumption of lacustrine deposition to be incorrect at this location in the ditch.

Rock retained on the screens is shown in Figure 32 . The largest rocks on the $\frac{1}{2}$ inch screen weighed between 50 and $150 \mathrm{~g}$ and had a major dimension in the 5-11 cm range. These were rhyolite pebbles, tending to be tabular in form.

Texture analys is of composite soils taken from two levels in square $4 E-4 S$ are given in the following table.

\section{TABLE $V$}

TEXTURE ANALYSIS OF SOIL SAMPLES: SQUARE $4 E-4 S$

$\begin{array}{llllll}\text { Level } & \mathrm{pH} & \begin{array}{c}\text { Sand } \\ \%\end{array} & \begin{array}{c}\text { Silt } \\ \%\end{array} & \begin{array}{c}\text { Clay } \\ \%\end{array} & \text { Classification } \\ 30-40 \mathrm{~cm} & 8.7 & 48 & 29 & 23 & \text { Loam } \\ 50-60 \mathrm{~cm} & 8.3 & 58 & 21 & 21 & \text { Sandy clay loam }\end{array}$

The quantity and nature of the clasts and the texture of the matrix at this location lead to the conclusion that the soil overlying the artifacts at location 75 is an alluvial flood plain deposit (Longwell and Flint 1962, Krumbein and Sloss 1963, Hunt 1972). While this may have been laid down in a single event it is more probably the deposition of a number of strong running floods. There is no visible stratification, 


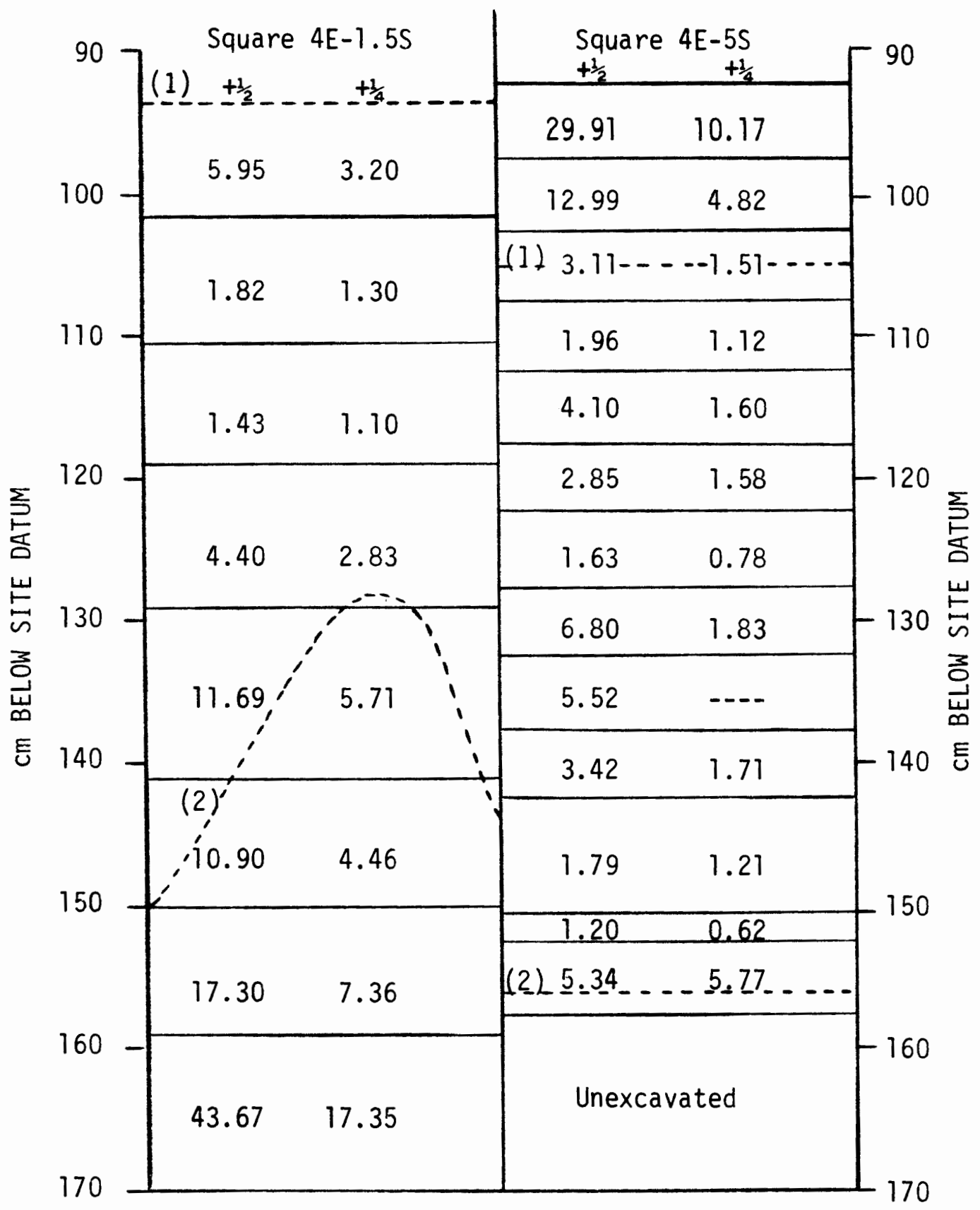

(1) Approximate original soil surface

(2) Approximate surface of gravel

Numbers designate $\mathrm{kg}$ of rock on screen of indicated size

Figure 32. Rock retained on screens at various levels of test excavations. 
however. The multiple flood inference is based solely on the thickness of the unit and the internal distribution of the clasts.

During a later visit to the site in April 1978, two additional artifacts were found in the ditch wall (Figures 11 and 15, locations 195 and 20.4S). The one at location 195 was a $13 \mathrm{~cm}$ long obsidian bipoint, about half exposed, with one end securely embedded into the ditch wall (Figure 33). The other at location 20.45 was an obsidian flake, apparently a snapped-off blade. It too was found end-on into the ditch wall, lying under a $10 \mathrm{~cm}$ wide gravel overhang (Figure 34 ). Because of its much shorter length $(2.7 \mathrm{~cm})$ it was not deeply embedded. Since it was found about $10 \mathrm{~cm}$ back under the overhang there is virtually no possibility that it was redeposited from the surface (Figure 35 ).

The Humboldt point base at 75 was lying on top of a filled erosion trench, just above a lake bottom surface dated from the abundant snails at $9620 \pm 50$ B.P. (USGS-460B). In the northwestern Great Basin this point type is known, primarily from rock-shelter sites, from about 60002500 B.P. It has been found more than a millennium earlier in the northeastern Basin (Heizer and Hester, 1978, Clewlow, 1967, Pettigrew, 1975). Unfortunately, with this broad time span the point is not helpful in dating the time of deposition of the overlying soil.

Mr. James B. Sweet, Department of Biology at Portland State University, examined the diatoms in the soil from the level of the Humboldt point. He found a modest population of Nitzschia thermalis, a diatom that normally grows attached to a substrate in a littoral zone in water of relatively high salinity. The same diatom, as well as other species, was found up to the surface. Since the deposits here were not lacustrine in 


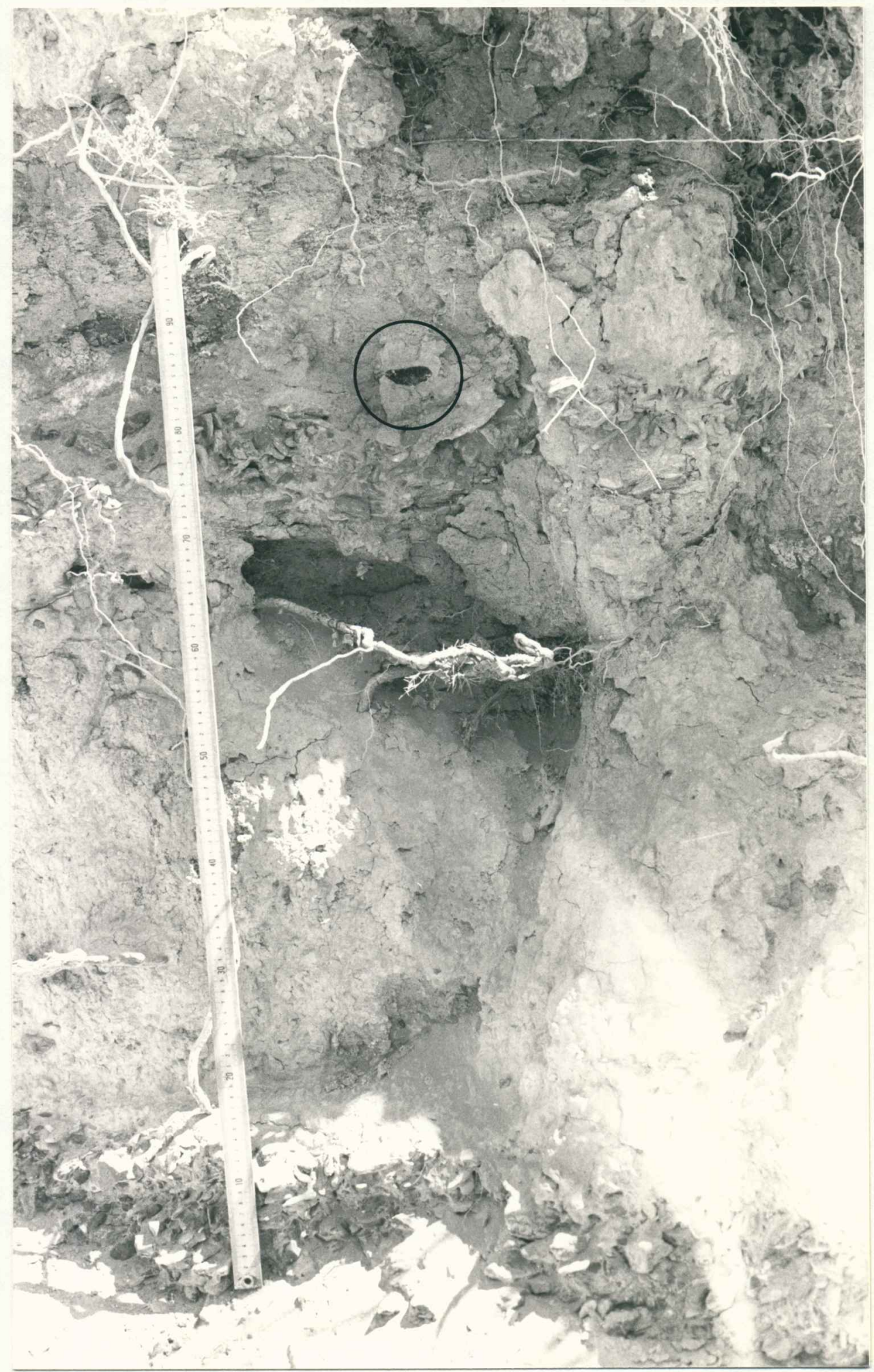

Figure 33. East wall of ditch at location 19S showing obsidian bipoint in situ. 


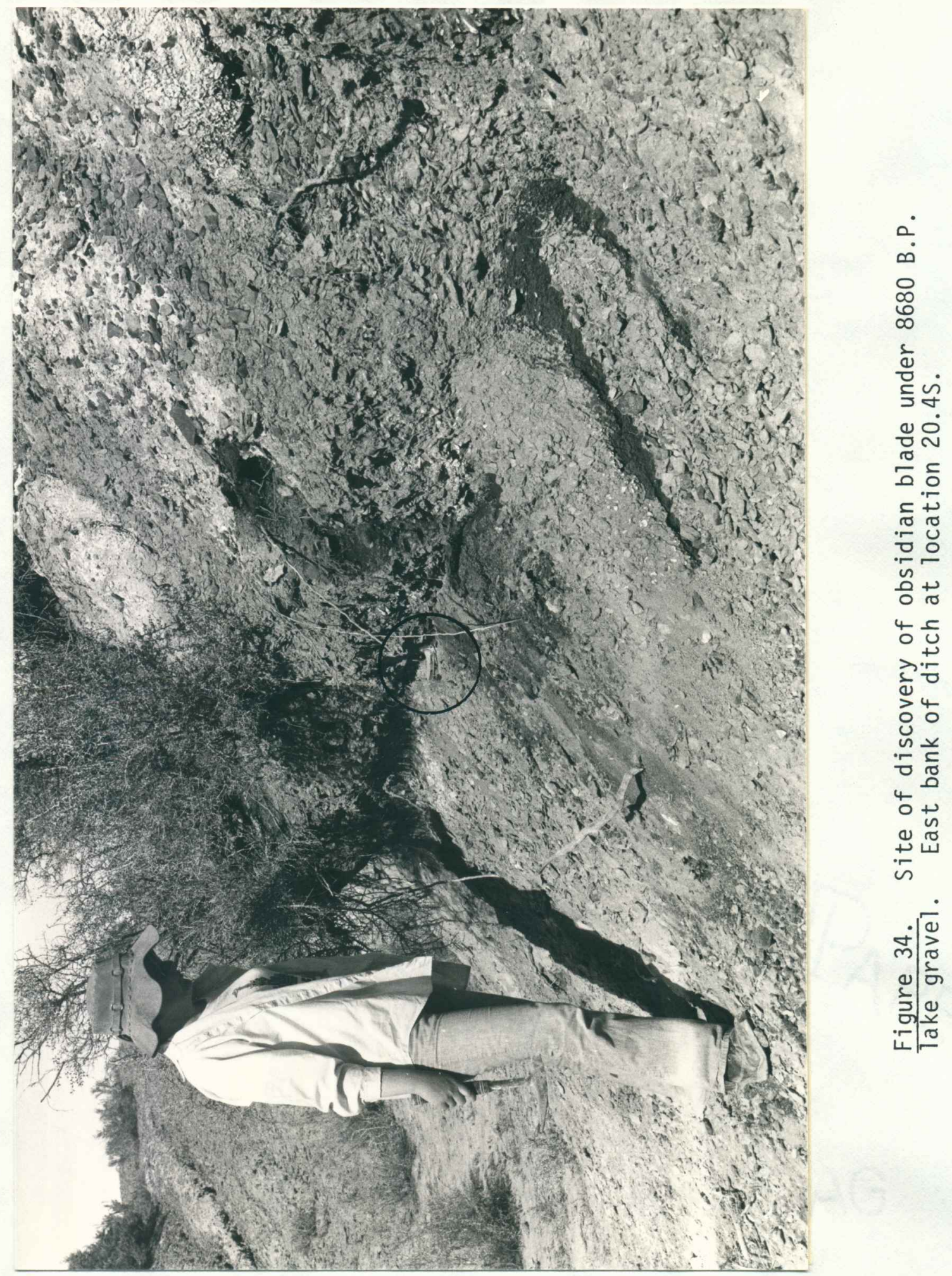




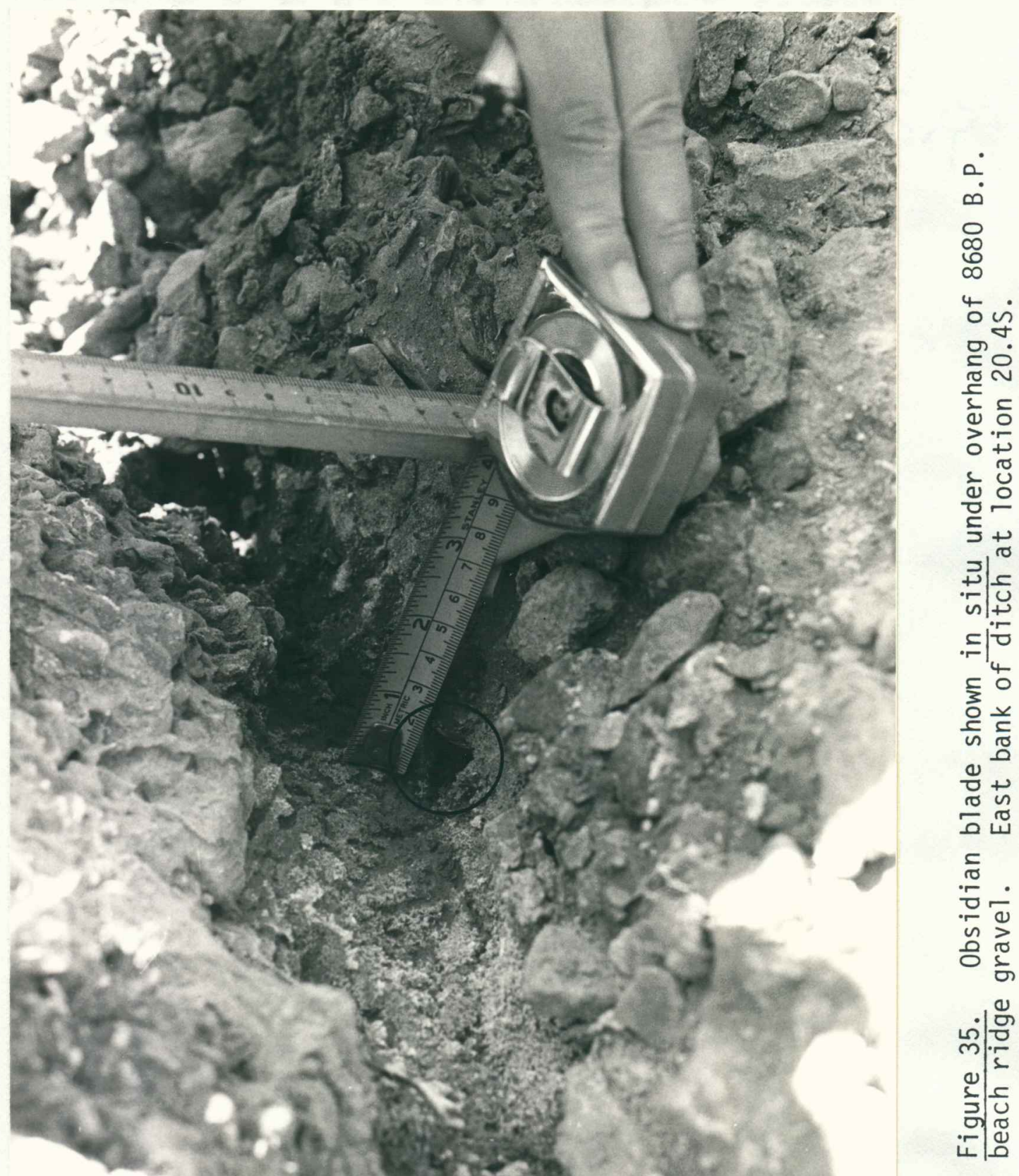


nature, it can be presumed that the diatoms and occasional snails were carried with the flood suspended load from an upstream location, probably from ancestral Weed Lake.

The filled trench underlying the Humboldt point was $42 \mathrm{~cm}$ deep and about $180 \mathrm{~cm}$ wide. It is best revealed in the East ditch wall, opposite the artifact location (Figure 36 ). This seems to be a transverse erosional feature, cut when the gravel at this point was emergent and before it was covered with waters of the 9620 B.P. lake. The trench was totally filled with lake bottom deposits before the artifacts were deposited. The relationship thus seems to be quite accidental.

The obsidian bipoint also lay just above a thin band of gravel which represents a lake floor surface, in this case somewhat younger than the one just discussed. The lake floor on which this artifact was found appears from the elevation of an associated beach ridge to be correlative with the highest terrace in the basin. This terrace has been dated from molluccs at 8680 B.P. (USGS-461B). The diatoms here were quite different, over $95 \%$ being of a single species, Navicula mutica. Mr. Sweet states that this diatom is "often found growing on moist soil and is indicative of a flood plain habitat." Analysis of soil texture at the point find showed a composition of $72 \%$ sand, $8 \%$ silt and $20 \%$ clay. The high sand content is suggestive of a near-beachline environment. Other geomorphic considerations are in full accord with this interpretation (Figure 15).

A third type of environment was represented at the location of the obsidian blade fragment. This lay under the same gravel deposit on which the obsidian bipoint was found, immediately below the leading edge of a 


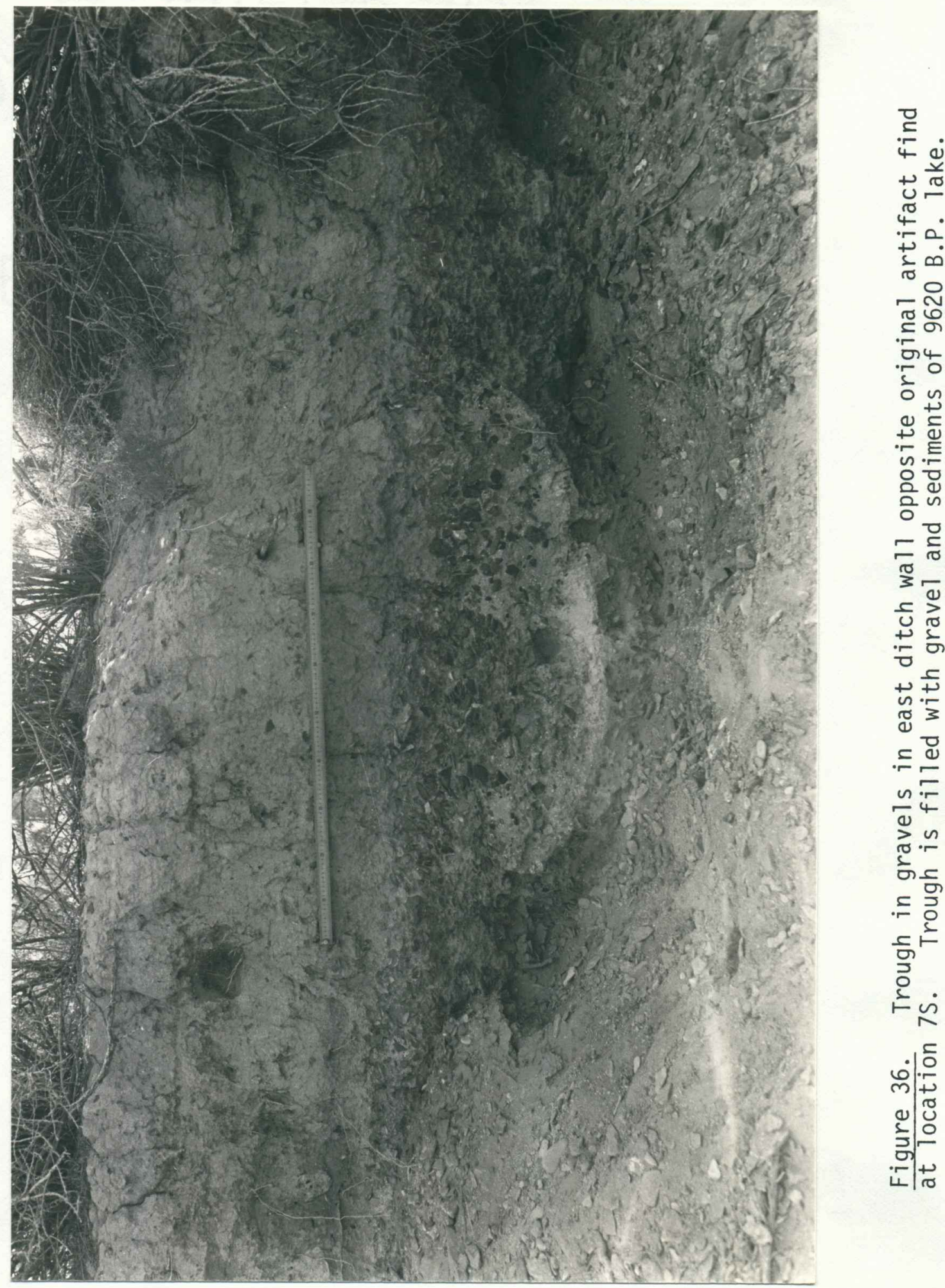


gravel beach ridge overlying an eroded earlier lacustrine soil. The blade fragment is stratigraphically below the bipoint in the upper surface of this soil. Mr. Sweet makes the following comments:

[Soil] sample 20.45 was fairly typical of a lake; i.e., one species [of diatom] dominant, a few quite cormon and many rare occurrences. The sample was dominated by Fragilaria construens, and other species of Fragilaria were common. These species grow attached to a substrate and can tolerate high salinity.

Soil texture at the blade fragment location suggested lacustrine origin, as did the lack of any apparent gravel in the silt. Here sand content was reduced to $23 \%$, silt was $53 \%$ and clay $24 \%$.

The Humboldt point was heavily patinated on one surface and quite fresh on the other. Microscopic examination revealed a very slight softening of fiake scar intersections (Figure 37 ). This indicates minimum action of erosional forces.

There was moderate patination on the lower surface of the obsidian bipoint from location 195 and slight patination on the upper surface (Figure 38). When found, it was oriented with its long axis at approximately right angles to the ditch and reclining at approximately $45^{\circ}$, with the upper edge facing away from the lake. Microscopic study showed slight wear of the flake scar intersections indicating a very minor amount of abrasion. The distal half of the point showed heavy edge wear. This attribute was wholly lacking on the proximal end suggesting (1) that this was not a projectile point; and (2) that it was probably hafted.

The blade fragment from 20.45 is sharp, fresh and unpatinated on either side (Figure 39). It too was oriented transversely to the ditch at about a $45^{\circ}$ angle but its upper edge was disposed to the north, toward the 


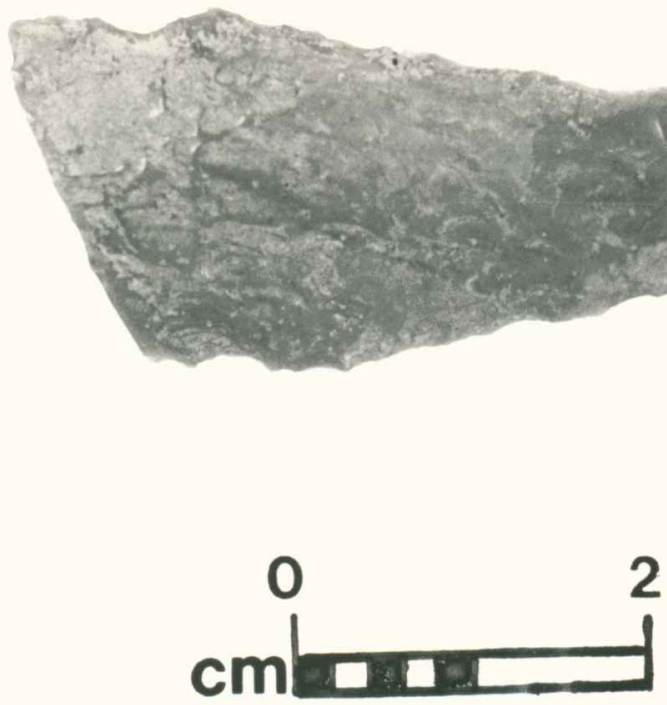

35 HA 342

Figure 37. Humboldt point found in ditch wall at location $7 \mathrm{~S}$. 


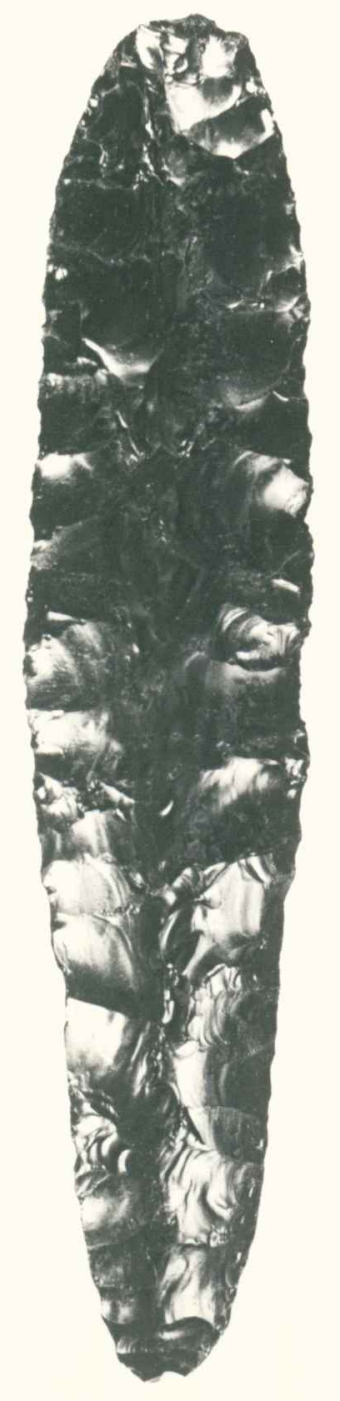

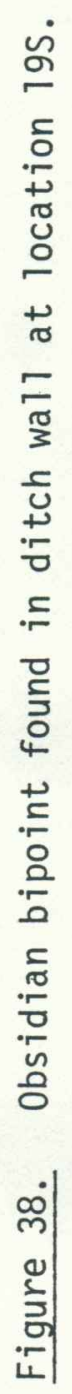



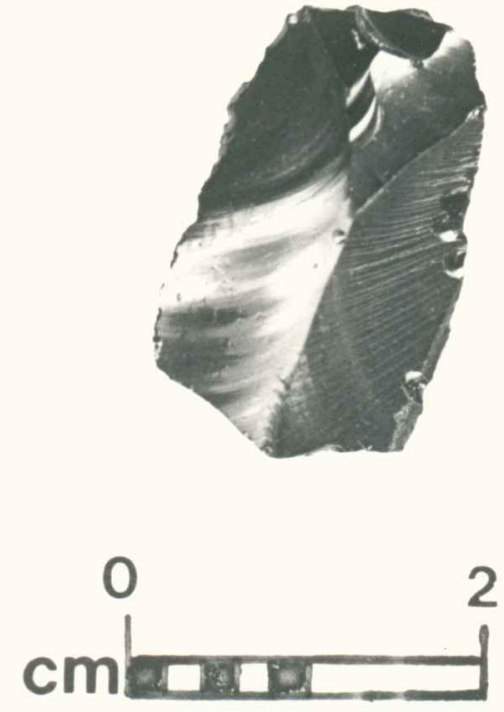

35 HA 342

Figure 39. Blade fragment found in ditch wall at location 20.4 S. 
lake. While it appears to be a fragment of a snapped-off true blade, this cannot be determined with certainty. The striking platform was crushed, apparently during manufacture.

Unfortunately, there is nothing in the geomorphic evidence that gives a definite answer as to when or how the Humboldt point and the other artifact adjacent to it came to their place of discovery. Since the silt column over the artifacts appears to have been deposited by a series of fast-running floodwaters it is within the realm of probability that the artifacts were also carried by one of these floods. However, the evidence does not preclude the point of discovery from being a primary location. The fact that the two artifacts were found so close together would support this viewpoint. The odds seem high against two artifacts having been picked up as bedload and then dropped only $30 \mathrm{~cm}$ apart. Thus, all that can be said with assurance is that they are probably younger than the 9620 B.P. surface underlying them.

The same statements largely apply to the two artifacts found in situ in the ditch wall at locations 195 and 20.4S. The obsidian knife at 195 is clearly younger than 9620 B.P. It must also be younger than the beach ridge on whose lakeside slope it was found. Since this beach ridge appears correlative with the terrace dated at 8680 B.P., that date can be assumed as a maximum possible age. The flood plain type silts in which it was embedded are supportive of this being a primary deposit.

The small obsidian blade at location 20.45 must be older than 8680 B.P. since it underlies that beach ridge. Again, the evidence supports primary deposition but does not fully exclude redeposition from another location. While this evidence is indirect, it clearly shows the 
presence of man in the Harney Basin by 9000 years ago. This is not at all unexpected. However, it is the only solid evidence to date other than the presence of ancient artifact types and these cannot be relied on for precise dating.

A ring of four sites, all at elevations between about 1252 and $1256 \mathrm{~m}$ (4107 to $4120 \mathrm{ft}$ ), lie within a $2 \mathrm{~km}$ radius of the location of the Humboldt point find. A fifth site also lies within this circle but it is located on a set of lagoon-enclosing barrier islands offshore from the study area (Figure 17). These sites will be briefly described.

\section{SITE 35HA341}

The largest of the sites, 35HA341, is big enough that a few diagnostic artifacts have even escaped the ubiquitous pot hunters. It lies on a finger of slightly elevated land that appears to have been a long peninsula into a shallow portion of Jackass Bay. This peninsula was formed by the beach ridge just described in connection with the artifacts found at locations 195 and 20.4S. Today the eastern end slopes away into the desert floor and presents a gap which would allow a lake to pass through and extend all the way to the mouth of Jackass Creek. Topographic considerations lead me to believe that this condition existed prehistorically as well.

The site ranges from 20 to 50 meters wide and is at least 700 meters long, although the highest concentration of artifacts is found in the 300 meters at the tip (eastern) end of the peninsula. The artifacts are topographically limited to the higher portion of the site. This suggests that there was either shallow standing water or marshland on both sides of the peninsula. Johnson (1965:451) and Sparks (1960:188) describe marsh 
formation behind a beach ridge in contexts almost identical to this one.

In a $125 \mathrm{~m}$ cross-sectional exposure through the ditch, between locations 215 and $27 \mathrm{~S}$, there is only 30 to $50 \mathrm{~cm}$ of soil over the gravel beach ridge. This soil was apparently deposited by the lake itself. It contains considerable sub-angular gravel. Flood deposition is unlikely due to the elevation of the site.

The few artifacts recovered include crescents, small leaf-shaped points, some with basal grinding, and what are apparently true blades (Figures 40 and 41). One unusual graving tool and a crescentic scraper were also found (Figure 42). Many of the abundant waste flakes show edge utilization.

Six artifacts from this site appear to be true blades (Figure 43 ). One is of chert, another of grainy opaque obsidian, and four are of a creamy, beige-colored chalcedony. The latter four were found within a 2 meter circle and were apparently struck from the same core. These small artifacts average about $1.5 \mathrm{~cm}$ wide, $3.5-4 \mathrm{~cm}$ long and 0.3 to $0.4 \mathrm{~cm}$ thick. The obsidian blade has been steeply flaked on one corner to make a small arcuate scraper. All of them have a dorsal arris. Two of the chalcedony blades on which the striking platforms are preserved have fairly prominent bulbs of percussion.

True blades are slowly being recognized at early Great Basin sites a)though they are as yet largely unreported. Dumond (1962) describes blade-like artifacts from Oregon, some of which closely resemble the present artifacts. However, many of the objects reported by Dumond apparently were not artifacts but instead were naturally occuring spalls of obsidian. Some of the cores may have been the spalled prismatic nodules 

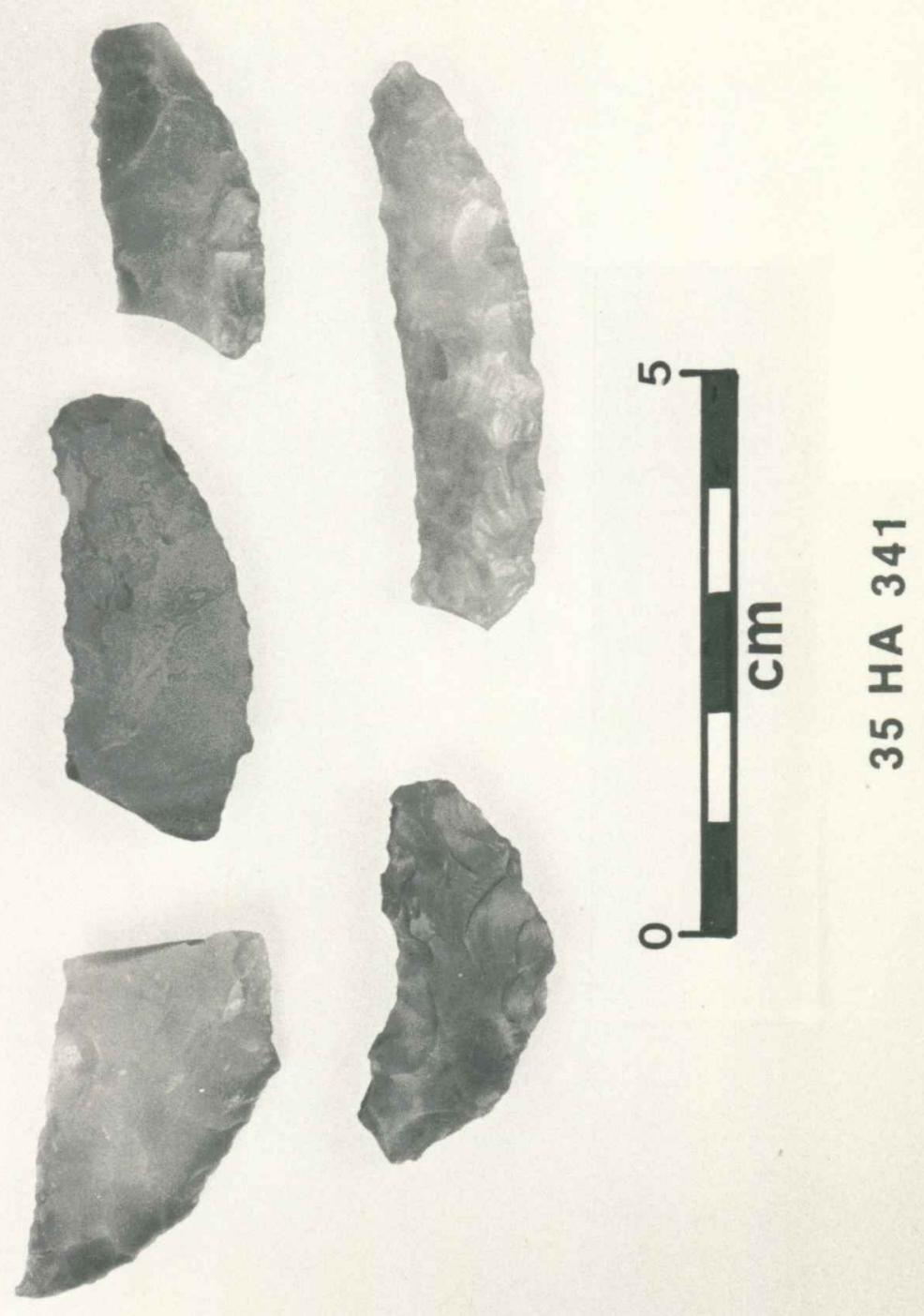

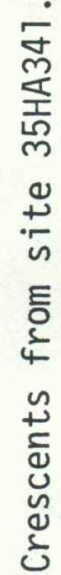

0
8
0
$\vdots$
밈
니 

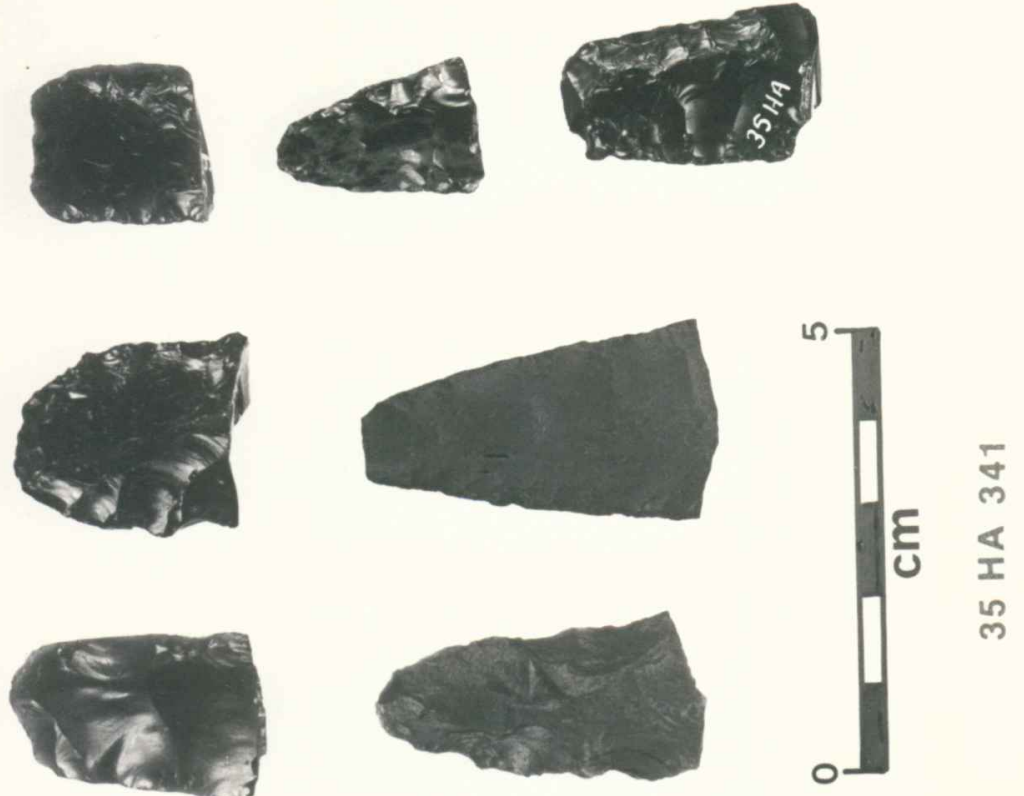

嵩
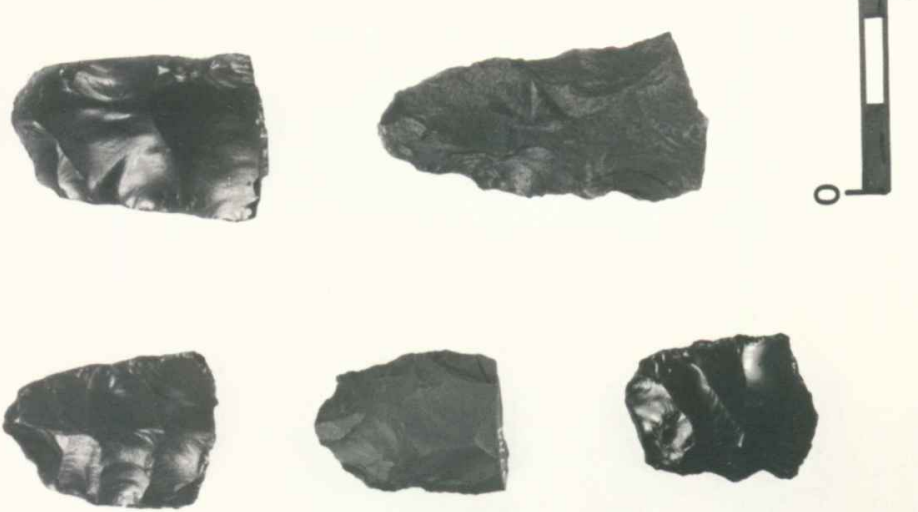

ث
ज
E
는

$n$
4
$\frac{1}{4}$
$\frac{1}{2}$
$\frac{1}{4}$

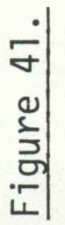




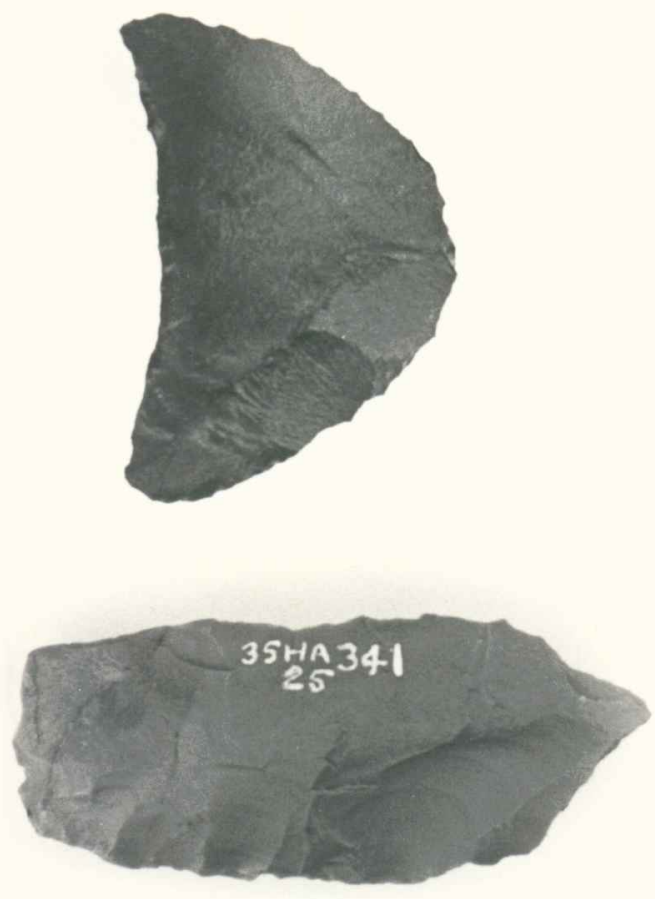

守

है

ฮั

过

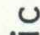

$\bar{\pi}$

$<$

ก

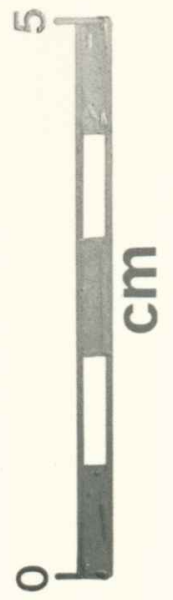

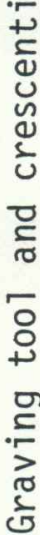

$\stackrel{\sim}{\sim}$

ఏ 


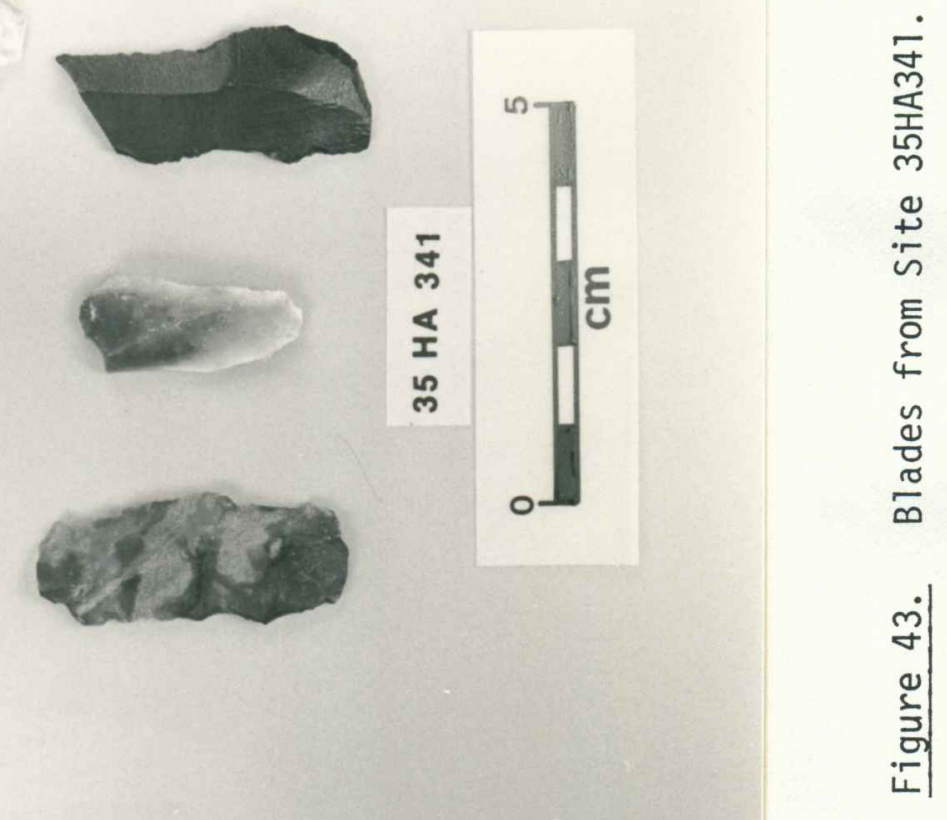


of this natural process (John H. Atherton, personal communication). One reason blades have not shown up more often on artifact inventories is that they have probably been unrecognized. Blades are not necessarily limited to ancient sites. The famous Ishi demonstrated punch striking of flakes or blades (Kroeber, 1961:182). Rare blades have also been noted by Atherton (1966:8) and others that he cites. Atherton's main work was at an obsidian quarry near Riley, on the eastern edge of the Harney Basin.

The 35HA341 site would have been in a particularly opportune location for use of the rich shallow water littoral zone and marsh at the lake edge. Its iarge size and high concentrations of waste flakes suggest that it was a favored location for a long period of time.

\section{SITE $35 \mathrm{HA} 343$}

The site lies on top and on the lake side of a beach ridge thrown up by the lake across a saddle between two buttes. The top of the earthen ridge is at about $1255 \mathrm{~m}$ elevation. It is thus correlative with the last high stillstand of Pluvial Lake Malheur at 8680 B.P.

The site is small and fairly thin. Behind it, in the saddle between the two buttes, is a small playa about $200 \mathrm{~m}$ in diameter. This playa was noted on the Wildlife Refuge as the location of site MNWR-147. No trace of that site was found in the place designated. Site $35 \mathrm{HA} 343$ is wholly outside the Refuge boundary.

The base of a broad-stemed Lind Coulee type point and the lightly edge-ground base of a leaf-shaped point were the only diagostic artifacts collected (Figure 44) (Daugherty 1956). Pettigrew $(1975: 20)$ gives a timespan for the Lind Coulee types as 10,500 to 8000 B.P. and for the leaf-shaped points as 10,000 to 5000 B.P. 


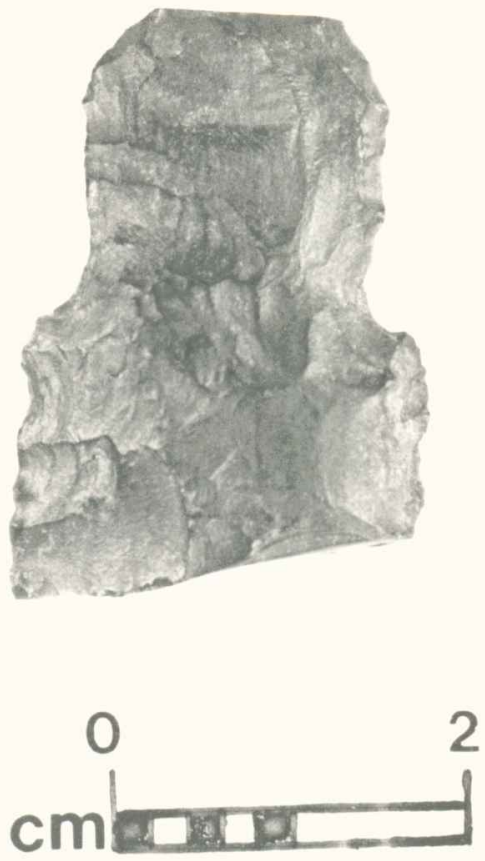

35 HA 343

Figure 44. Lind coulee point base from Site $35 \mathrm{HA} 343$. 


\section{SITE $35 \mathrm{HA} 344$}

This very small site was on top of and behind a beach ridge thrown up between two buttes. It is about $1.2 \mathrm{~km}$ south of $35 \mathrm{HA} 343$ in a very similar geomorphic situation. Here, occasional artifacts were found on the small playa between the buttes and behind the beach ridge.

One of the artifacts from the playa was a classic type of chert blade (Figure 45). This blade was $4.88 \mathrm{~cm}$ long, $2.44 \mathrm{~cm}$ wide and had a maximum thickness of $0.59 \mathrm{~cm}$. The blade retained a well-formed striking platform at its proximal end. There was a centrally located arris on the dorsal surface and a very shallow bulb on the ventral side. All evidence indicates this to be a deliberate blade, perhaps punch struck.

A second blade-like artifact of obsidian was also found on the playa. This was moderately thick and had cortex on the proximal half of the dorsal surface. Whether it was a trimming flake from a blade core or simply a long narrow flake, is a matter of conjecture.

The third artifact from the site was a small, almond-shaped point with an asymmetrically located stem. This appears to be morphologically close to Lind Coulee points (Figure 45 ).

\section{SITE MNWR-143}

This site, about $50 \mathrm{~m}$ wide and $400 \mathrm{~m}$ long, was on the wave cut terrace at the northeastern entrance to Jackass Bay. It was located along the edge of a butte at an elevation between about 1253 and 1256 meters. It faced into the bay rather than being oriented toward the lake. The land here sloped gently into the bay yet the artifacts disappeared suddenly below the lower of the above contours. Of all the sites, this one 

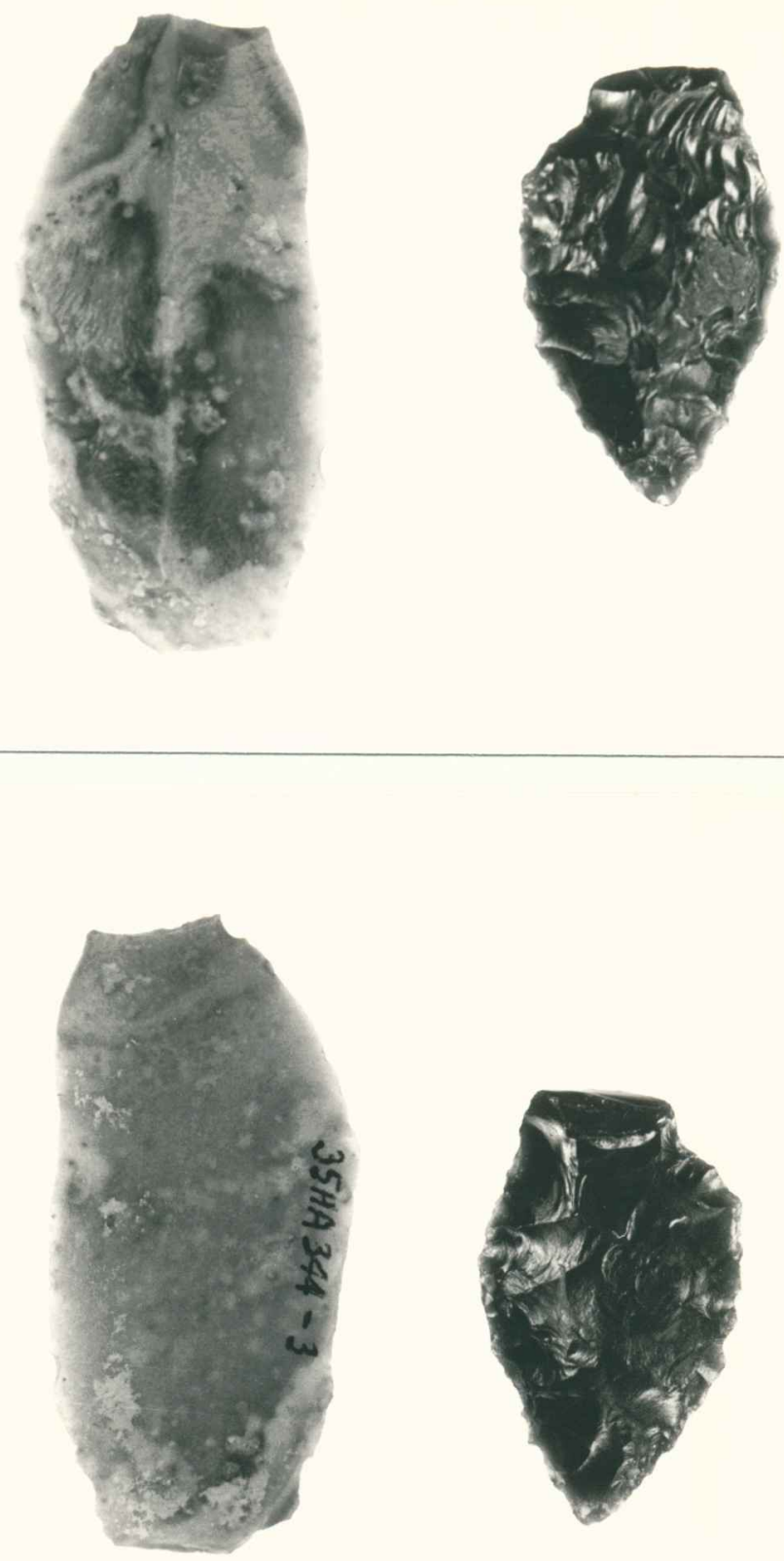

$\begin{array}{lll}0 & 2 \\ \mathrm{~cm} & 35 \mathrm{HA} 344\end{array}$

Figure 45. Chert blade and Lind Coulee point from Site 35HA344. 
appears to be the most sharply delimited on the lakeside edge. There does not appear to be any plausible explanation for this other than the presence of standing water virtually to the edge of the site. If this explanation can be accepted, the site must have been occupied shortly after the lake abandoned the terrace. There is a thin mantle of soil between the artifacts and the deposit of snails which marked the lake floor. These snails provided the date of 8680 B.P. which marked the high (overflow) stand of the lake.

This location is very accessible and the site has been almost totally looted. A few bases were found which appeared to be from leafshaped points. One broken crescent was also found. It can only be assumed that these artifacts are associated with the site. Regrettably, it has a good camp area which is frequentiy used by pot hunters. One group encountered there was highgrading the day's loot from other areas by discarding fragments and unwanted specimens. No artifacts from the vicinity of this camp area were considered in the evaluation of the site.

\section{SITE 35 HA340}

A chain of low gravel barrier islands encloses a shallow lagoon off the mouth of Jackass Bay. There is a continuous thin scatter of flakes on these islands. Their elevation is about $1246.2 \mathrm{~m}(4086 \mathrm{ft})$ and they presently stand no more than 1-2 meters at most over the surface of the playa. In my judgement they could only have assumed their present form during the last major stillstand of the lake when the series of beach ridges at $1250 \mathrm{~m}(4100 \mathrm{ft})$ was formed. All of the artifacts are from moderately to heavily rolled. A high portion of the flakes appear to have edge utilization but this may be simply due to battering among the beach 
gravel.

Three formed artifacts were found. One was approximately half of a crescent that, if whole, would have been about $8.5 \mathrm{~cm}$ long and $2.1 \mathrm{~cm}$ wide. Another was the base of a broad point, classified as an Elko corner-notched type. The third was the mid-section of a broad $(2.9 \mathrm{~cm})$ point having exquisite diagonal ribbon flaking on one face. The crescent is suggestive of an early date, perhaps older than 6500 B.P. (Pettigrew 1975:20). The Elko point is regarded as much more recent, having a reported time span from about 3500 B.P. to later than 600 A.D. in the western Great Basin (0'Conne1 1967:135). Heizer and Hester (1978) quote possible dates for this type as early as 8000 B.P. for the northeastern Basin.

\section{$\star \star \star \star \star$}

In summary, this group of sites seems to represent early lake margin occupations. With the exception of $35 \mathrm{HA} 340$, each appears to date to, or immediately after, a high stand of Pluvial Lake Malheur about 8700 years ago, when the lake was filled to overflowing. Occupation may have commenced at some of the sites as the level began to drop and the Basin became intermittently, and then finally, hydrographically isolated from the Columbia River system. Site $35 \mathrm{HA} 340$ is younger and undated. It is probably associated with a drying phase of the lake when the lagoon within the enclosing barrier islands became a shallow littoral zone or marsh. Site 35HA342 is really a geomorphic site rather than an archaeological site. Even so, it holds evidence of occupation in the Harney Basin prior to the high stillstand of the lake at 8700 B.P.

Grinding or milling tools were notably absent in all of the sites. 
This too is in keeping with the interpretation of an early time of occupation. Negative evidence of this type does not bear on questions of the presence or importance of milling stones to the early desert peoples. Nobody seriously questions that milling stones were present from almost the earliest times. The evidence is equally clear that they did not assume great importance, as judged by relative abundance, until a much later date (Cressman 1977). It was not until the advent of the Desert Archaic culture about 8000 to 7000 B.P. that milling tools became plentiful in the desert dweller's tool kit (Jenning 1974; Fagan 1974). In the present case the absence of any milling stone fragments may speak equally to site age and type of economic activity. It is evidence which should not be dismissed but used with caution.

Here, the geomorphic evidence has been combined with the archaeological evidence to paint a much fuller picture than if either stood alone. Topographic considerations, obviously used with discretion, should be useful in predicting where other sites of the approximate 8000 to 9000 B.P. age class may be found in the Harney Basin. Obviously, the careful reverse use of the data for estimating the age class of certain sites should also be valid. While there are many clear pitfalls in this age-landform relationship, it at least provides a tool for testing site age hypotheses.

C. Faunal Analys is

Here I will report and discuss the significance of the faunal material collected from the study area. This falls into four categories; large mammalian bone, fish bone, diatoms and molluscs. 


\section{Mammalian Bone}

Three fossil large mammal bones were found in or near the drainage ditch. Thomas Martin of the Burke Museum, University of Washington, kindly examined these. He attributed two limb bones to Cervidae, cf. Odocoileus. On the basis of my own later examination I am inclined to assign one tentatively to Cervus on metrical and comparative grounds (Gilbert 1953). Cervus canadensis (wapiti or elk) is a species still found in or adjacent to the Harney Basin on Steens Mountain. Odocoileus hemonius occurs throughout the Basin. The third bone is tentatively from a large carnivore.

Specimen 35HA342-3 cf. Ursidae. This sample comprised most of a left ischium and about two thirds of the acetabulum. It was found as float on the gravel fan about $210 \mathrm{~m}$ north of the ditch mouth. The ramus had been crushed by cattle trampling but most pieces were recovered. The approximate diameter of the acetabulum is $50 \mathrm{~mm}$ yet the depth does not appear to exceed about $15 \mathrm{~mm}$. In a purely subjective rating this appears to be the most heavily mineralized of the fossils.

A full range of comparative material is not available at the Burke Museum to assign this definitly to a genus. It is morphologically similar to but decidedly larger than Ursus americanus. The Museum does not have a skeleton of $\underline{U}$. horribilis for comparison. However, the pelvic fragment is similar in size and gross morphology to U. maritimus, a bear of similar size to the grizzly. The grizzly bear is known to have persisted in the Harney Basin until approximately historical times (Ferguson and Ferguson 1978:48). 
Specimen 35HA342-4 cf. Cervus. This is the shaft portion of a left humerus. It was found in situ in the ditch wall in apparent flood plain alluvium at location $28 \mathrm{~S}$ (Figure 11 ) about $1 \mathrm{~m}$ below the trailing edge of the gravel beach ridge attributed to the 8700 B.P. maximum lake elevation. Specimen length is $225 \mathrm{~mm}$. The estimated length of the complete bone is at least $300 \mathrm{~mm}$. Neck width at the point of minimum size above the olecranon fossa is $29.4 \mathrm{~mm}$ and depth at this location is $38.9 \mathrm{~mm}$. This is the least mineralized of the bones.

Specimen 35HA324-5 cf. Odocoileus. This is the major portion of a left metatarsal (metapodial). The distal articular surface was lost at the unfused epiphysis. Mrs. Doreen Church contributed this bone and stated that it was found "in the ditch." Total length of the specimen is $202 \mathrm{~mm}$. The estimated length if complete is about $230 \mathrm{~mm}$. The width of the neck at the smallest location about $3 \mathrm{~cm}$ below the proximal articular surface is $23.2 \mathrm{~mm}$. Depth of the bone at this location is $26.3 \mathrm{~mm}$. The specimen is somewhat shorter and more robust than the modern 0docoileus hemonius skeletal material used for comparison.

There is some very small mamalian bone present in the material retained on the finest screen from the southwest quarters of excavated squares $4 E-0.5 S$ and $4 E-4 S$. Very little of this has been separated and none has been identified to date. This faunal material will be the subject of a future report.

\section{Fish Bone}

There is a very thin scatter of fossil bone, predominantly fish verebral centra, found on the northeastern portion of the Harney Lake 
playa. In addition to bone collected from this location by the Field School, I recovered several grams of small fish bone from the snail lens on the lakeside face of the 32,000 B.P. beach ridge (Figure 13). A few of the vertebrae from the playa are shown in Figure 46 . Most of the bone was examined by Dr. Kevin Howe, Oregon State University, who made tentative identifications. The large vertebrae from the playa fall in the morphologic range of both Oncorhynchus and Salmo. However, Dr. Howe believes the latter genus is the more likely. Age estimates of the vertebrae of Figure 46 lend some strength to the attribution to Salmo. To my untrained eye these appeared to have from five to seven annuli (Casteel 1976). This estimate was narrowed to six to seven annuli by the independent examination of two biologists at the National Marine Fisheries Service laboratory in Seattle, Washington. Oncorhynchus tshawytscha (chinook salmon) is the only Pacific salmon to migrate as far inland as the Harney Basin. This species today does not normally exceed five years age at spawning although some may spawn as late as their eighth year (Hart 1973:125). Nor do they usually include a major freshwater lake in their migration route (R. B. Herrmann and Dr. Jack LaLane, personal communication).

It seems more probable that these fish were ancestral relations of one of the strains of very large Salmo gairdneri or clarki known historically in the Snake River system. They may have been either native or anadromous types when the Harney Basin was open to the Columbia River system. In either case and regardless of species, they could have been taken with relative ease during spawning runs in the tributary streams of the pluvial lake.

The bones are from large fish that by very rough estimate could be 


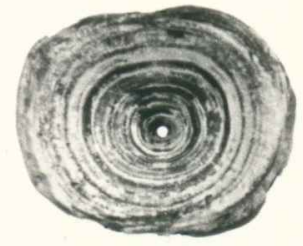

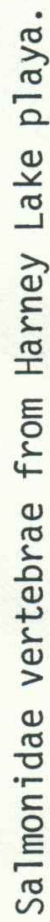

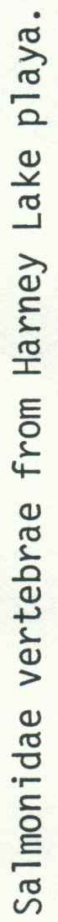
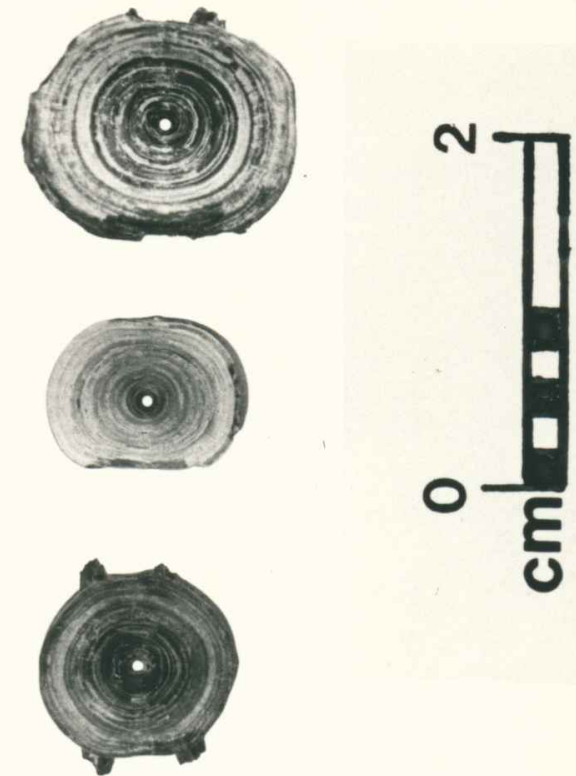

बे
है
조․
틍
$\frac{1}{4}$

ปั

苛

\begin{tabular}{c|}
$\dot{y}$ \\
| \\
$\frac{1}{3}$ \\
문
\end{tabular}

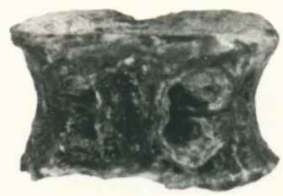


in the $3-10 \mathrm{~kg}$ class. It is almost unthinkable that such a resource was not important to the inhabitants of the Harney Basin. Hardman and Venstrom (1941:71) report that "enormous quantities" of trout were taken aboriginally from the Truckee River. To further quote them:

Indians, from as far distant as Lovelock, gathered on the banks of the Truckee River at the beginning of the first high water in the spring, when countless numbers of Pyramid Lake trout and other fish ascended the river to their spawning grounds ( $p .71)$.

Individuals of Salmo clarki weighing up to $18 \mathrm{~kg}$ have been taken from Pyramid Lake (Hart 1973:127).

Several of the sites in the present study area would be in an opportune location to take advantage of such a spawning run as it moved from the main lake into Jackass Creek.

Further research should be able to determine whether these fish were nonmigratory trout or whether they were salmon that entered the Basin from the Columbia River system. Several species may have been present. Present day Paiute living at the Burns reservation recall taking salmon from the South Fork of the Malheur River, not far away from its former entrance into the Harney Basin (Marilyn Coture, personal communication). The whole matter merits more serious investigation. It is quite possible that these fish persisted in Pluvial Lake Malheur long after its Columbia River connection was severed by dropping water level.

The fish bone from the 32,000 B.P. snail deposit had representatives tentatively attributed to Catostomus (suckers) and Gila (minnows). These could have been important food species for both humans and the large trout.

While not the remains of a fish, an unusual small hemispherical 
"pebble" found in the ditch bottom gravel proved to be a crayfish gastrolith (R. B. Hermann, personal comunication). This indicates the presence of another potentially important food source not generally considered a part of the diet of early desert people.

3. Diatoms

Diatoms are widely used for stratigraphic correlation and environmental inference by geologists but they appear to have been almost totally ignored by archaeologists. Only Cressman (1942:115-116), of all the authorities consulted in the preparation of this paper, appears to have considered them. I wish again to acknowledge Mr. James B. Sweet, Department of Biology, Portland State University, for his willing assistance in identification and for comments on habitat types. Much of what follows will be quoted or reworded from his reports. Reference is made to Figures $10-15$ for sampling locations.

a. Soil samples from Location $16 \mathrm{~N}$

(1) Upper stratum, above $G_{2}$ gravel layer.

The very few diatoms were all typical freshwater species, the most important being Fragilaria pinnata, F. vaucheriae, Melosira distans, Melosira sp.

(2) Soil stratum between $G_{1}$ and $G_{2}$ gravel layers.

Rather plentiful freshwater diatoms included Melosira distans, Melosira sp., Fragilaria pinnata, F. vaucheriae, Cymbella affinis, Denticula thermalis, Suriella ovata, and others less abundant.

(3) Soil stratum beneath $G_{1}$ gravel ("Jackass Soil").

There were many diatoms, but slightly fewer than in the middle 
layer. This lower soil contains more "planktonic" species typical of an open water habitat (e.g., a lake). Present were Melosira sp., Amphora ovalis, Stephanodiscus astrea, Rhopalodia gibba and other less common diatoms.

In summary, the upper and middle samples contained more diatoms that typically grow attached to a surface such as rocks, submerged vegetation or bottom sediment. Diatoms in the lower sample were more typical of an open lake.

I believe Mr. Sweet's summary fully supports the conclusions already drawn for the three strata at this location. In the case of the middle layer I proposed deposition in an ingressive shallow lake. The lower part of the upper stratum; i.e., the portion sampled here, was deposited in a relatively shallow littoral zone. Diatoms also give supportive evidence about the silt accumulating in the lake contained by the 32,000 BP beach ridge; i.e., the Jackass Soil. This appears to have been deposited in relatively deep, open water - an observation also borne out by soil texture analysis.

b. Samples from the soil column in Square 4E-4S.

(1) 24-30 cm stratum (Figure 32 ).

Diatoms present were predominantly Navicula mutica and Nitzchia thermalis.

(2) $30-40 \mathrm{~cm}$ stratum.

Principal species were Navicula mutica, N. elginensis, Denticula thermalis, Nitzchia spp.

(3) $40-50 \mathrm{~cm}$ stratum.

The diatoms here were essentially the same as in the layer above. 
(4) $50-60 \mathrm{~cm}$ stratum.

Present were Nitzschia thermalis (majority) and Navicula elginensis (minority). This could indicate a warmer, more saline source.

(5) $60-70 \mathrm{~cm}$ stratum.

Nitzschia thermalis is dominant. There were fewer diatoms than above.

In general, there are no species shared between the $16 \mathrm{~N}$ location and those $500 \mathrm{~m}$ north (1akeward) of the test excavation site. However, commonality of species is found with samples taken south of the excavation site. This is further evidence to support the conclusion that the soil at the test excavation location is flood plain alluvium, transported from sources to south.

c. Samples from artifact locations 195 and $20.4 \mathrm{~S}$

Soil samples were taken immediately adjacent to the artifacts found at locations $19 \mathrm{~S}$ and $20.4 \mathrm{~S}$. The diatom evidence was reported earlier in the description of site $35 \mathrm{HA} 342$ but will be repeated here.

\section{(1) Location 19S}

The sample at 195 was taken from a sandy soil immediately above the thin band of gravel which becomes a beach ridge attributed to the 8700 B.P. lake. Mr. Sweet reports the sample to be unusual since "over 95\% of the diatoms were a single species, Navicula mutica. This species is often found growing on moist soil in a flood. plain habitat." I interpret this as a beach location coeval with the 8700 B.P. lake. It was possibly exposed shortly after this lake began its retreat. 
(2) Location $20.4 \mathrm{~S}$

The diatoms were dominated by Fragilaria construens and other Fragiliaria species were common. These species grow attached to the substrate. They can tolerate high salinity but are not restricted to such an environment. "My intuition (a guess) tells me that the sample came from fresh to moderately saline conditions - not as highly saline as some previous samples examined."

d. Samples taken near surface at 275 .

The diatoms are attached forms from fresh water of relatively high salinity. Diatom density was average. Navicula mutica was the dominant species. Nitzschia spp., Surirella robusta, Pinularia sp. and others were also present.

e. Soils at location 285 .

(1) Upper friable soil at 285

The upper and lower soils were roughly the same. The upper had more Cymbella spp. and more Fragilaria spp. than the lower, suggestive of "cleaner" less saline streams or lake shores.

(2) Lower heavy soil at 28S.

Melosira spp., Nitzschia spp., and a few others were slightly more prevalent than in the upper soil. This may indicate a slightly more saline environment of origin.

Both samples had the highest diversity of all that I examined, and also the highest density. These samples are similar to the diatom communities found in present day surface water of arid regions. 
f. Soil from snail layer at location 34S.

Diatom density and diversity were fairly high. Epithermia turgida was dominant and Melosira spp. were cormon. The latter species may be either planktonic or attached to substrates. Among the other species, Cocconeis sp. grows attached to aquatic vegetation. The remainder of the diatoms suggest contradictory conditions. Fragilaria spp. and Navicula spp. indicate "normal" fresh water, but the presence of Denticula thermalis indicates warmer and more saline conditions. "The diatoms are thus representative of fresh and saline waters, warm and 'normal' temperatures and lake and littoral conditions." The snails, to be described later, are representative of a well-vegetated marshland.

\section{g. Terrace snail deposit soil}

Soil associated with the snails on the wave-cut terrace facing into Jackass Bay contained Navicula mutica as the dominant diatom. "Because of the larger diversity of diatoms I feel this water was somewhat cooler and less saline than the other samples." This interpretation is fully in keeping with what would be expected in the lake at its maximum expanse and depth and with outflow into the Malheur River to provide freshening.

h. Dune ridge

A sample from the aeolean soil in the ring of dunes at the north end of Weed Lake Flat had "very few diatoms." Only Nitzschia sp. and fragments were present. Again, this finding is in keeping with the geomorphic history of the soil source.

Gladfelter (1977) and many others have emphasized that cooperation in the field is essential if maximum benefit is to accrue between the archaeologist and the collaborating specialists of other disciplines. 
The diatom data made a very positive contribution to the interpretation of the complex depositional history of the present study area. But because my collaborator could not be on site with me to guide sampling, the diatom data fell short of their full potential. Nevertheless, I would commend this as an untapped interpretative resource to others studying lake margin settings, who may be able to work under more favorable conditions.

\section{Molluscs}

Fossil molluscs have been by far the most important faunal material to the present project. They have been useful, among other things, as indicators of stratigraphic boundaries and beach lines. They are the sole datable material found that could place the geomorphic events in an absolute time frame. And they have borne a fair share of the environmental reconstruction.

The use of molluscan materials is not new in either archaeology or Quaternary Great Basin geology. In the United States, Cressman (1942) was possibly the first to include a separate section describing the Mollusca at an archaeological site and to use them for paleoenvironmental interpretation (Baker 1942). Enbysk (1956) included a checklist of Mollusca found at the famous Lind Coulee site, along with pictures of most of the species. She did not use her data to draw environmental inferences, however. In Cressman's report of his excavations at The Dalles, Oregon, Taylor (1960) wrote a brief section on the paleoenvironmental implications drawn from mollusc remains. Allen and Cheatum (1960) summarize the types of useful archaeological information that can be obtained from snails. In addition, they list 50 species found in Texan archaeological sites with their preferred habitats. 
Except for Cressman's (1942) cited work, molluscan fauna seem not to have greatly excited Great Basin archaeologists, at least as a tool for interpretation of past environments. Perhaps one reason for this is a shortage of skilled collaborators with the specialized knowledge to identify and interpret the specimens. Enbysk (1956) points to the highly fluid state of gastropod classification and the paucity of published literature from which to draw environmental information. Even though almost 25 years have passed since her report, the situation has not changed. There is no simple handbook the archaeologist can use to quickly acquire competence in mollusc identification and interpretation.

Even though molluscs have been neglected by Great Basin archaeologists, the Quaternary geologist has made far better use of them. As examples, Morrison (1964:73) has drawn inference about environmental change in the Carson Desert from changes in gastropod populations. Williams et al. (1962) used fossil snails for dating and to assist in geomorphic interpretation of a complex lake basin. In this case, the geology of Bear Lake, Utah-Idaho, has been greatly complicated by a late history of faulting and major landslides imposed on Quaternary climate change. Broecker and Kaufmann (1965) summarize about $150{ }^{14} \mathrm{C}$ dates for the Lahontan and Bonneville Basins. About one third of these were obtained on molluscan remains.

Call (1884) of the U.S. Geological Survey published the first extens ive checklist of Great Basin Mollusca. This was not updated until a study by Roscoe (1961) listed 79 species. Beetle (1961) identified 153 species found in Wyoming, many of which are common with Great Basin populations. Finally Taylor (n.d.) surveyed the species presently living 
in the Malheur National Wildlife Refuge. He found 15 species representing 6 families of freshwater snails and 5 species within two families of freshwater clams. These are listed in Table VI. Because of high water, Taylor was able to do only a little stream collecting and he did not sample many of the springs. He estimated that perhaps six more species would be found in the Refuge if a fully comprehensive survey could be made.

In view of the paucity of freshwater malacologists, I am fortunate that Dr. Taylor agreed to examine the fossil mollusc species collected during the field studies. He identified members of six families of freshwater snails containing 11 species and two families of freshwater clams with 5 species present. Two clam species and one snail are now regionally extinct. These are listed in Table VII. The collection localities are given in Table VIIa.

Table VII gives presence and absence data but it does not show relative abundance. This has been generally indicated on the stratigraphic sections but some further comments are needed. Where snails were found in a deposit (i.e., a relatively dense lens or band at least several centimeters thick), one of two species clearly predominated. In the deposit in and immediately underlying the beach ridge between stakes $\emptyset$ and $3 S$; i.e., the ridge dated to 32,000 B.P., Vorticifex effusus was the majority species. Fontelicella hendersoni and Helisoma newberryi were present as minority species, in that order of abundance. All of the other species together comprised only a few percent of the total. On the wave cut terrace, $F_{\text {. }}$ hendersoni was solidly dominant. Here $\underline{V}$. effusus was a small percentage and $\underline{H}$. newberryi was not observed. This situation was 
TABLE VI

FRESHWATER MOLLUSCS FROM MALHEUR NATIONAL WILDLIFE REFUGE, OREGON

\section{FRESHWATER SNAILS}

Family Valvatidae Valvata humeralis (Say)

Family Hydrobiidae Fontelicella hendersoni (Pilsbry)

Family Lithoglyphidae

* Lithoglyphus turbiniformis (Tryon)

Family Lymnaeidae

*Lymnaea caperata (Say)

L. nuttalliana (Lea)

Family Planorbidae

Armiger crista (Linnaeus)

Gyraulus circumstriatus (Tryon)

G. parvus (Say)

Planorbel1a subcrenata (Carpenter)

Vorticifex effusus (Lea)

Promenetus exacuous (Say)

P. umbilicatellus (Cockere 11)

Family Physidae

Physa gyrina (Say)

Physa sp.

Aplexa hypnorum (Linnaeus)

FRESHWATER CLAMS

Family Unionidae

Anodonta californiensis (Lea)

Family Sphaeriidae

Musculium lacustre Muller)

M. securis (Prime)

Pisidium casertanum (Poli)

$\star$ P. ins igne (Gabb)

*Species found outside the Refuge but expected to be found within the boundaries in suitable habitats.

Data are quoted from Taylor n.d. 


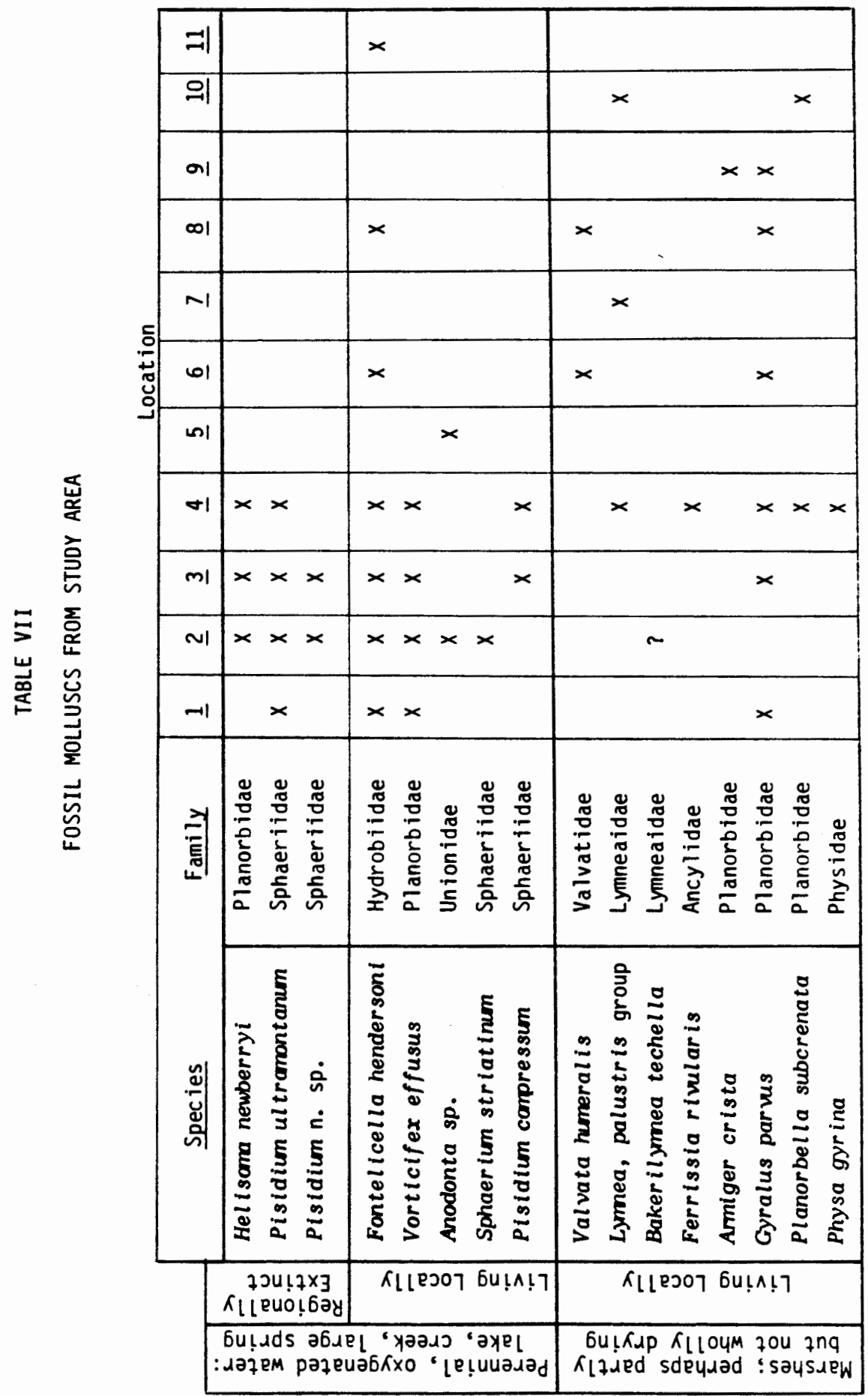


TABLE VIIa

SAMPLING LOCATIONS OF FOSSIL MOLLUSCS

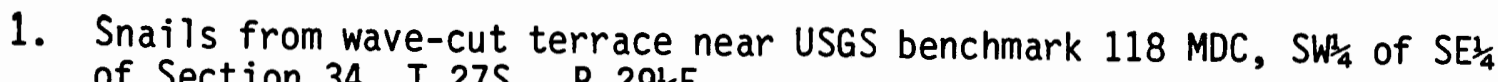

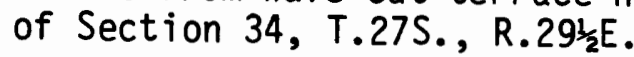
2. Snails from lens on lakeside face of gravel fan at stake $\emptyset$ in east
wall of ditch.

3. Snails from heavy deposit just above ditch floor in east wall, $11 \mathrm{~m}$ south of stake $9 S$.

4. Selected specimens from silt deposits above main snail bed near stake $9 \mathrm{~S}$.

5. Large mussel shell fragments from snail bed below beach ridge,
between stakes $2 S$ and $3 S$. 6. Small snails from anthill on top of beach ridge just west of ditch
near stake $20 \mathrm{~S}$.

7. Snails from east wall of ditch just below surface in silt between $20 \mathrm{~S}$ and 215 .

8. Snails from east wall of ditch just above tail of beach ridge gravel
$10 \mathrm{~m}$ south of stake 325 . 9. Small snails from upper silt in east bank of ditch between stakes $36 \mathrm{~S}$
and $37 \mathrm{~S}$.

10. Snails from various locations from east wall of ditch near stake 385.

11. Snails from anthills on barrier islands off mouth of Jackass Bay. 
similar in the $700 \mathrm{~m}$ long 9620 B.P. deposit, but H. newberryi was present in a very small percentage. This snail seemed to be more abundant near the associated beach ridge where the snails were densest and rare near the lake end of the exposure. A similar population makeup was noted in the as-yet-undated lowest deposits near location 5S. Comparatively, F. hendersoni was always present in a greater percentage when it was the dominant snail than was $\underline{v}$. effusus when it was the first ranked species. The clams were always found in a very low percentage. 
Mussels, Anodonta Sp., were present only in the two deposits where V. effusus was the dominant snail. They were common but not plentiful in the snail band underlying the beach ridge from just south of location $\emptyset$ to about 5S. This was the only part of this band exposed.

Some species were rare. I found only one individual of the tiny limpet, Ferrissia rivularis, a single clam of Sphaerium striatinum and two shells of Physa gyrina. While Dr. Taylor did not so note, apparently Armiger crista and Bakerilymnea techella are also rare.

The break between marsh species and species from perennial welloxygenated water is also much cleaner than might be implied from Table VII. For example, at locations 1 and 3, Gyralus parvus was a small fraction of $1 \%$ of the total population and at location 8 only one or two individuals of $\mathrm{F}$. hendersoni were found. Between locations $8 S$ and $12 S$, the beach ridge series for the 9620 B.P. lake, the large Lymnea, palustris group and Planorbella subcrenata snails are found primarily above the bands of $F$. hendersoni and only very rarely in association with them. This is a clear indication that the trough centered on location 95 had silted in and become a lake margin marsh when the large snails lived there.

Figures 47 to 57 show 11 species of study area molluscs for reference. A word of warning, however. There are many genetically distant look-alikes in the world of molluscs and pictures alone cannot take the place of a skilled malacologist.

Once again, the value of in-the-field cooperation between the archaeologist and other specialists is apparent. Had I then known the respective habitat types of the various snail species, the whole process of 

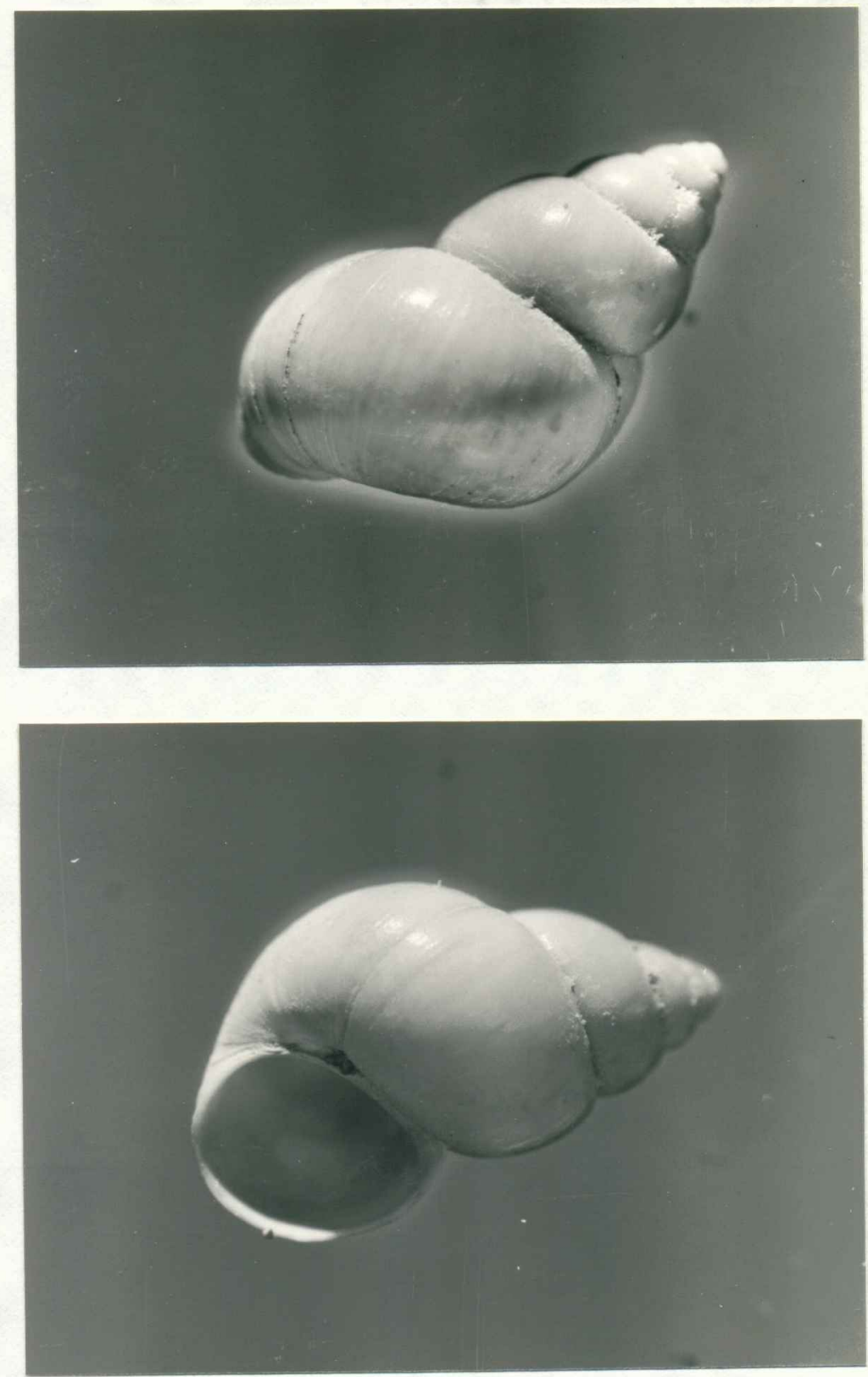

Approx. $5 \mathrm{~mm}$

Figure 47. Fontelicella hendersoni, $\underline{\text { c } 10.8 X}$ 

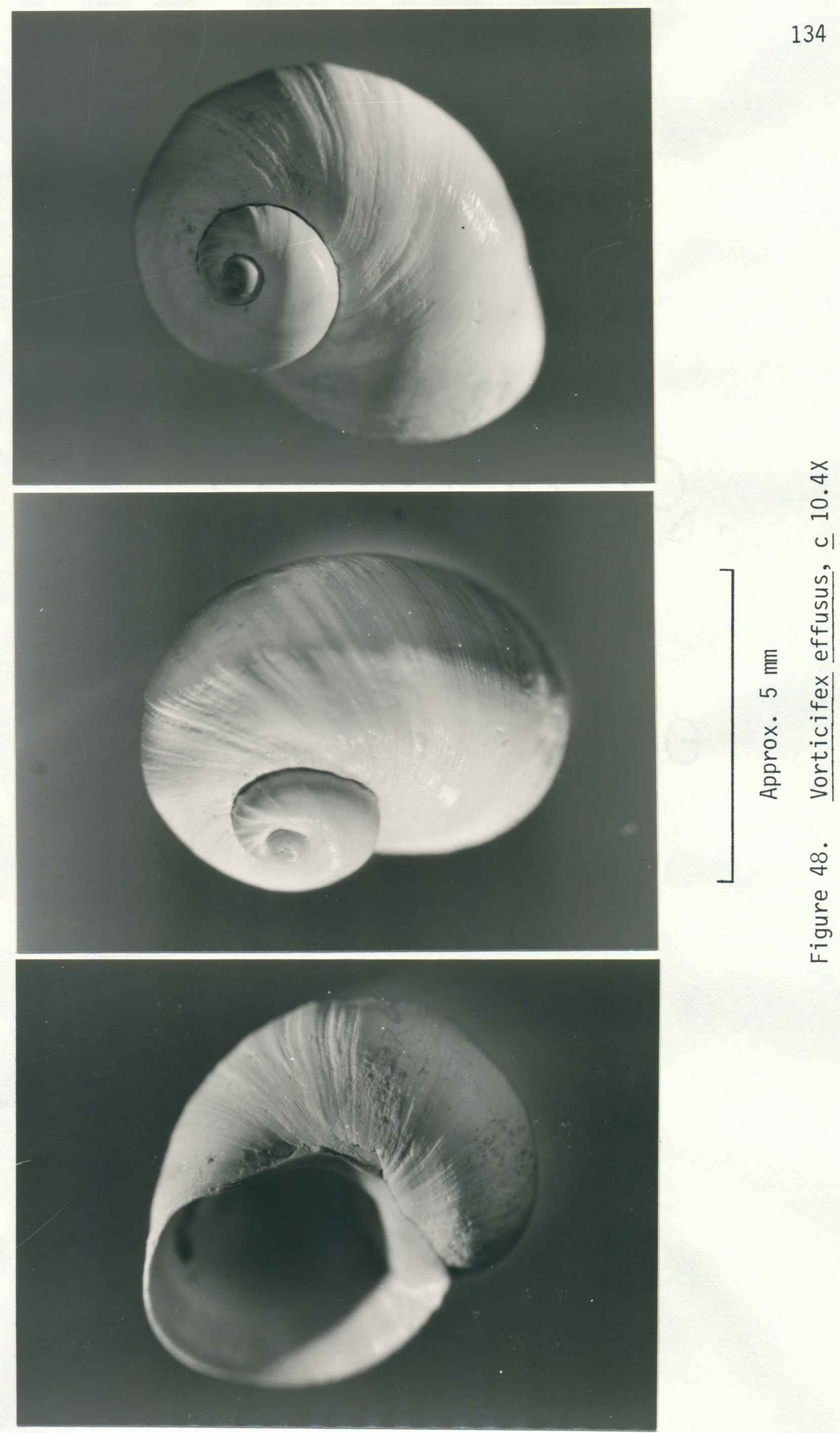

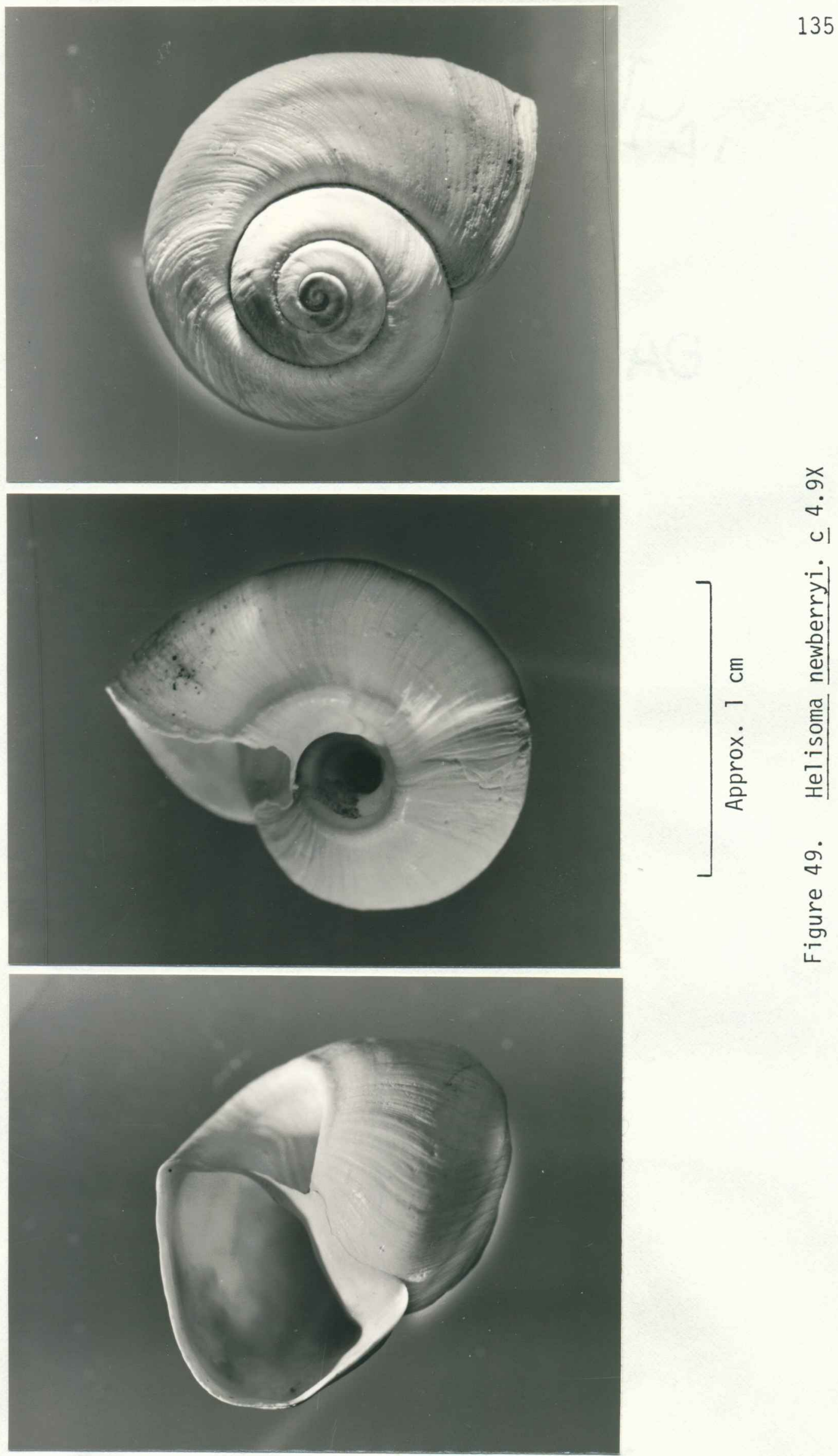

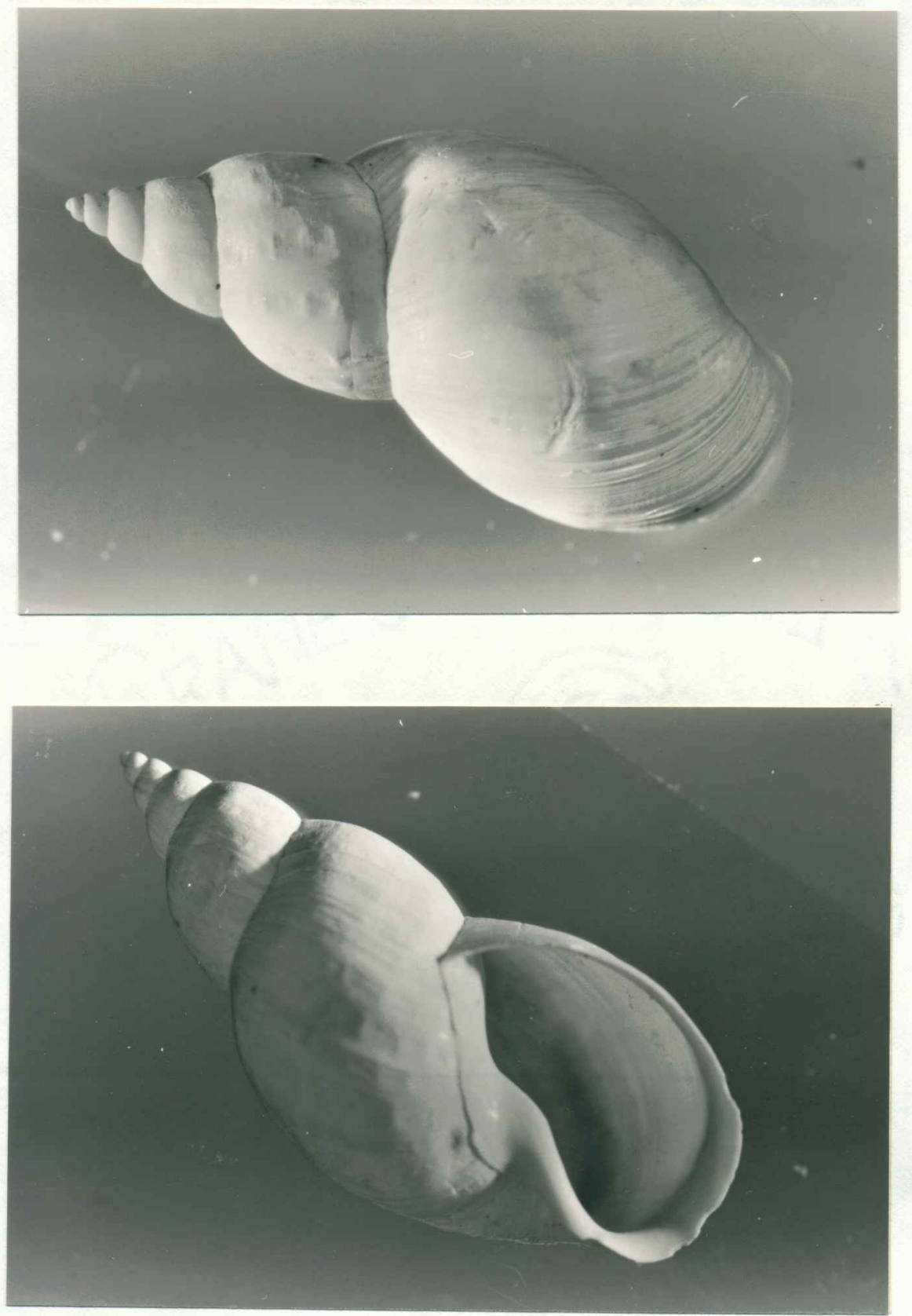

Approx. $1 \mathrm{~cm}$

Figure 50. Lymnea of the palustris group, $\underline{c} 4.4 \mathrm{X}$ 


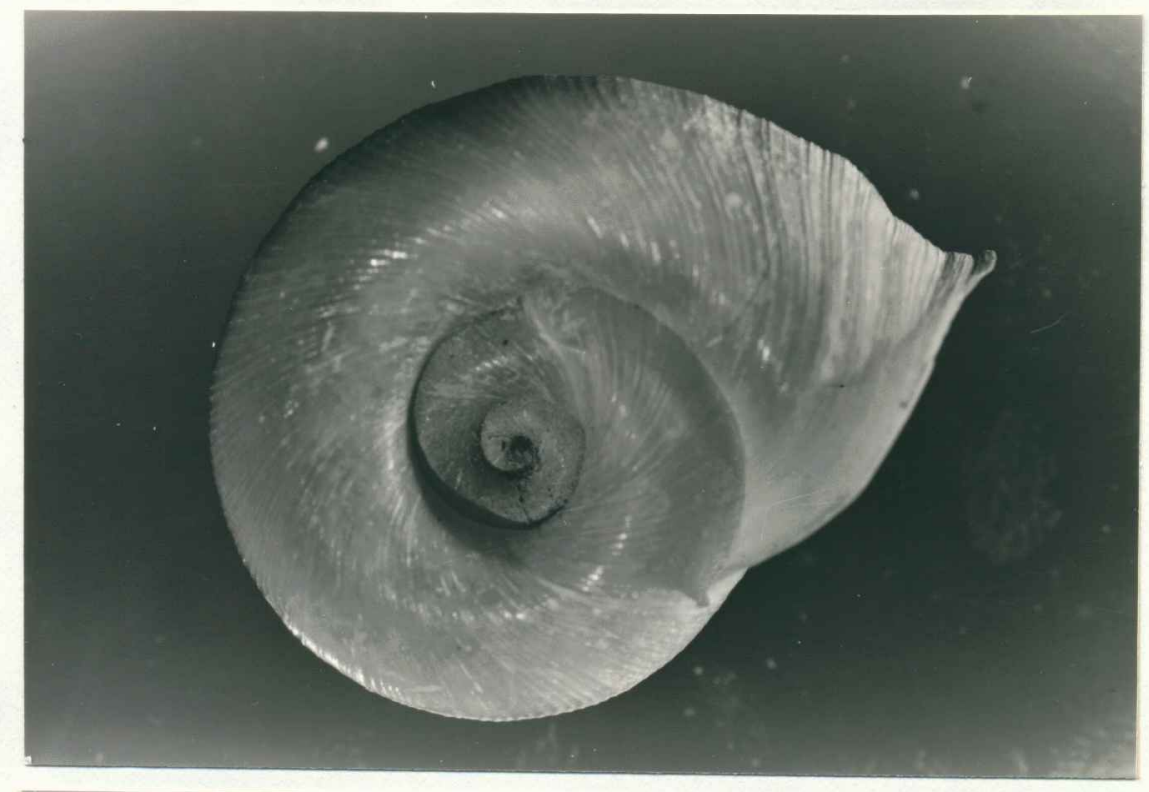

137
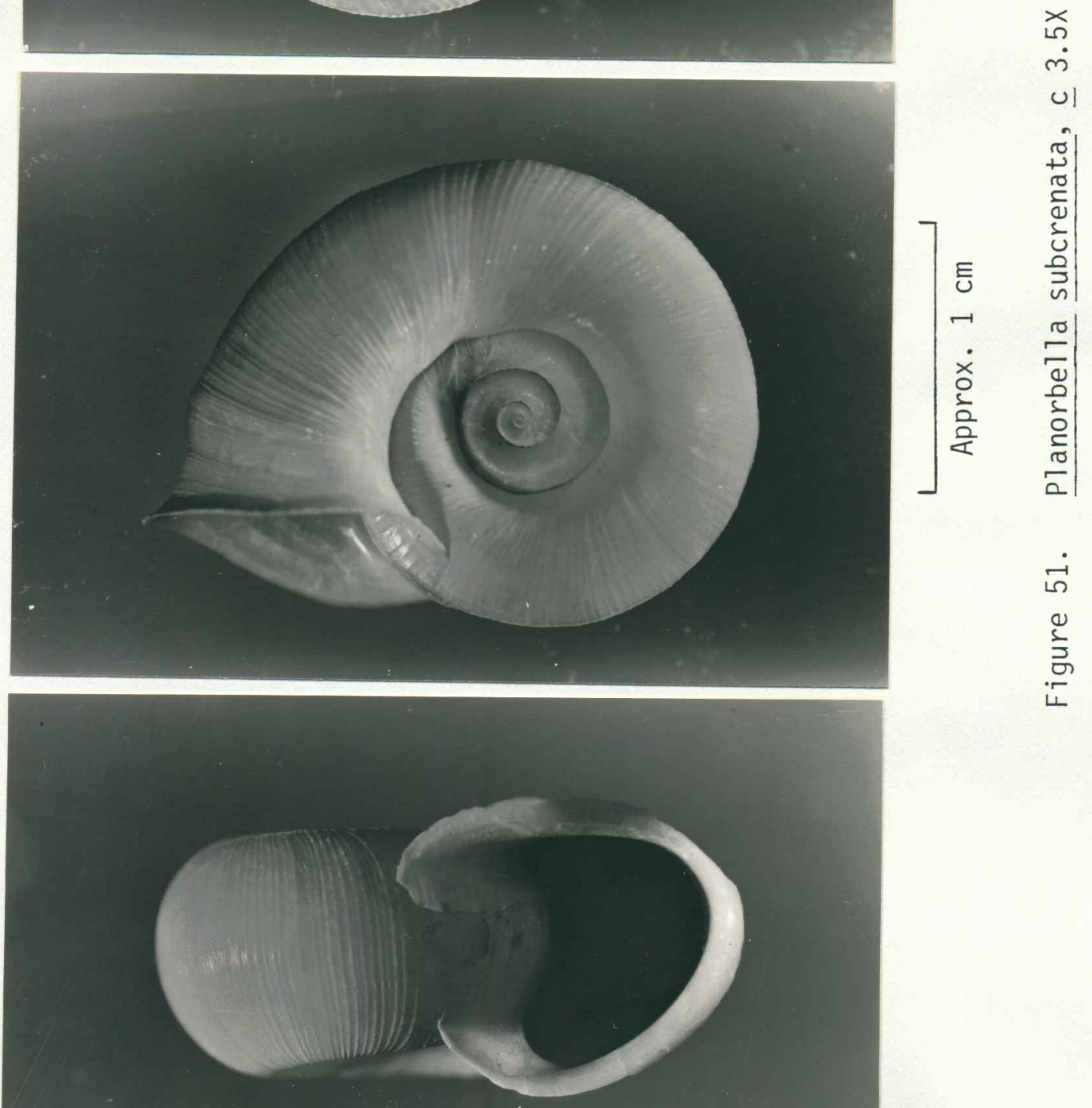

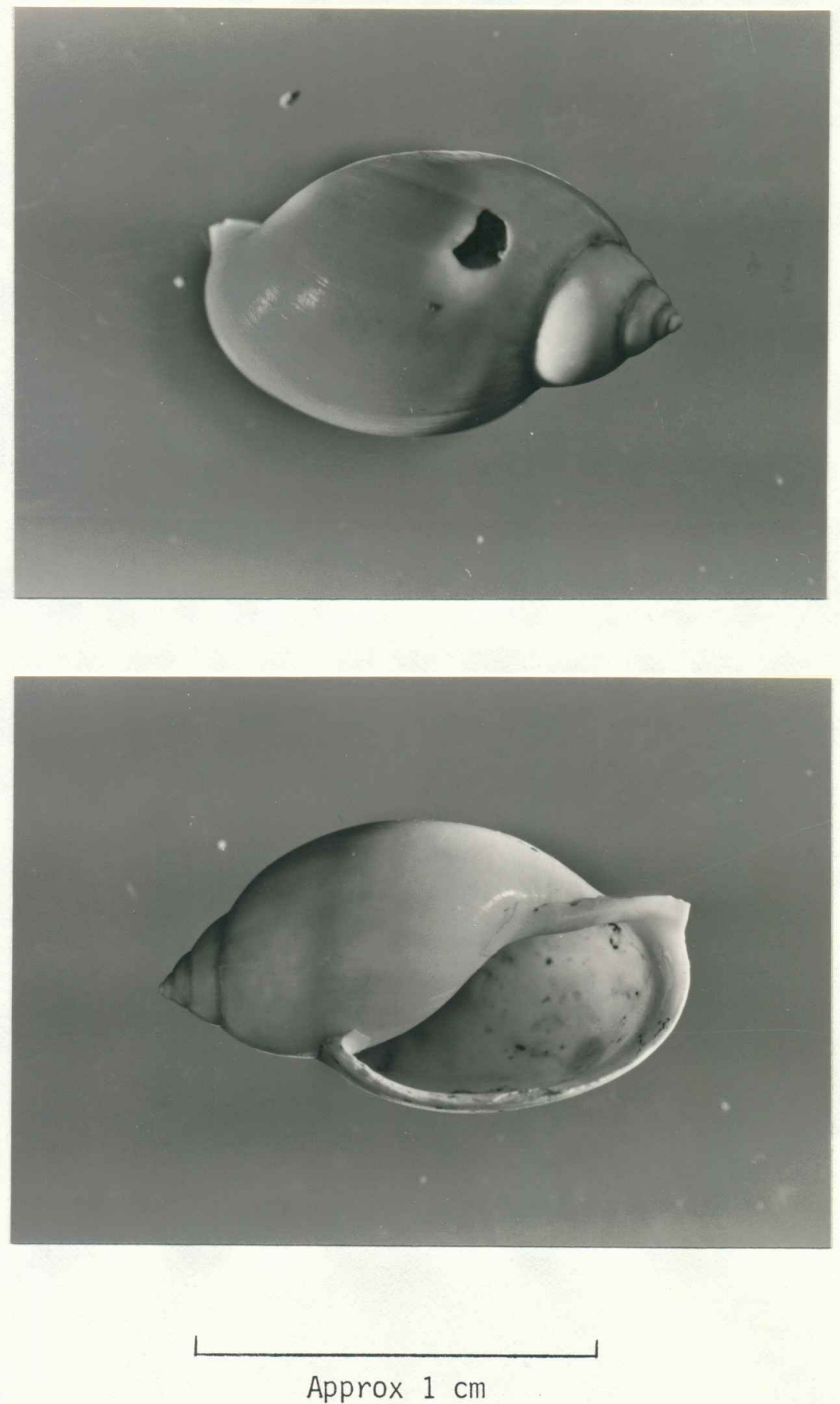

Figure 52. Physa gyrina, $\subseteq 5.2 \mathrm{X}$ 

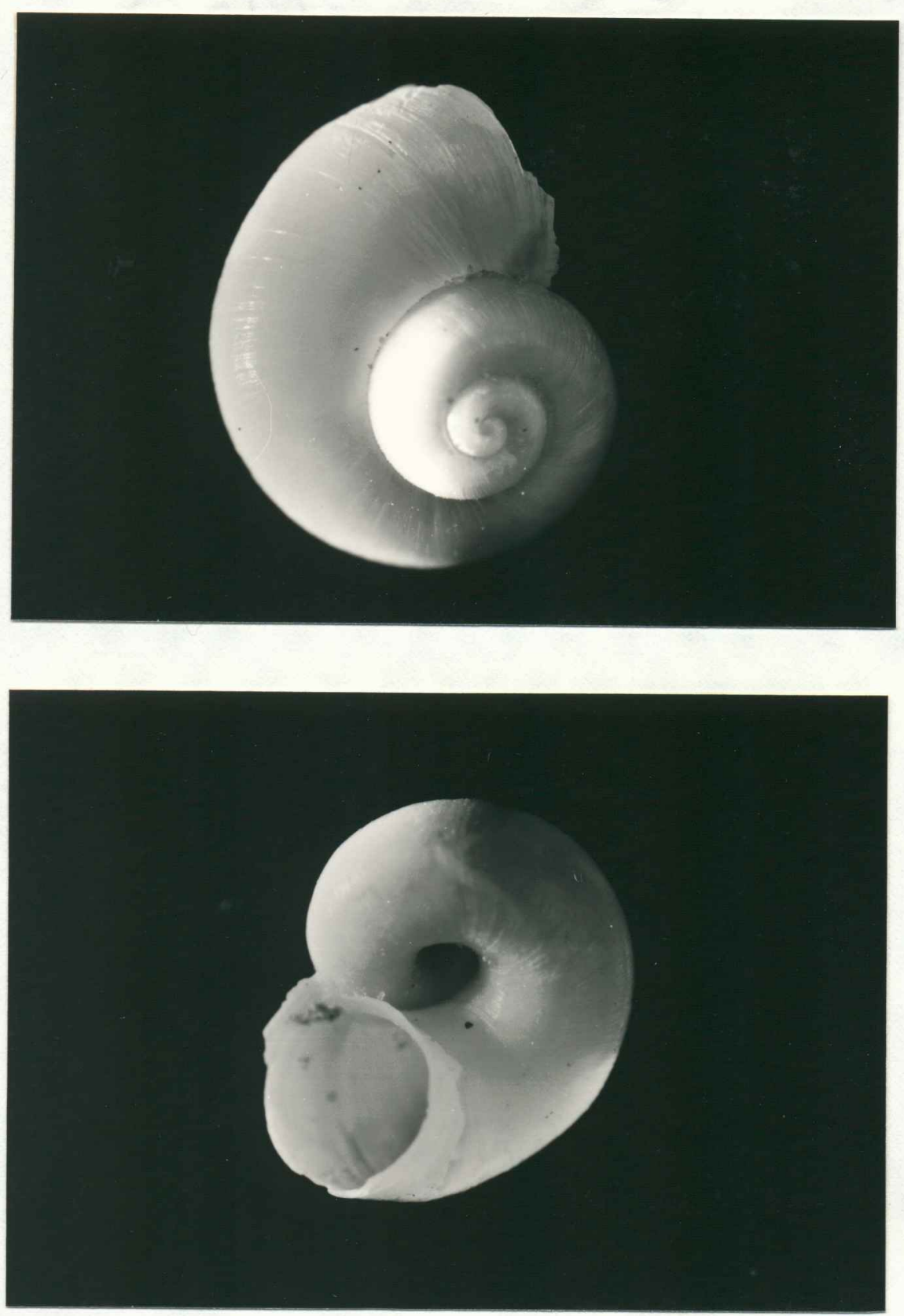

Approx. $3 \mathrm{~mm}$

Figure 53. Valvata humeralis, c $17.9 \mathrm{X}$ 

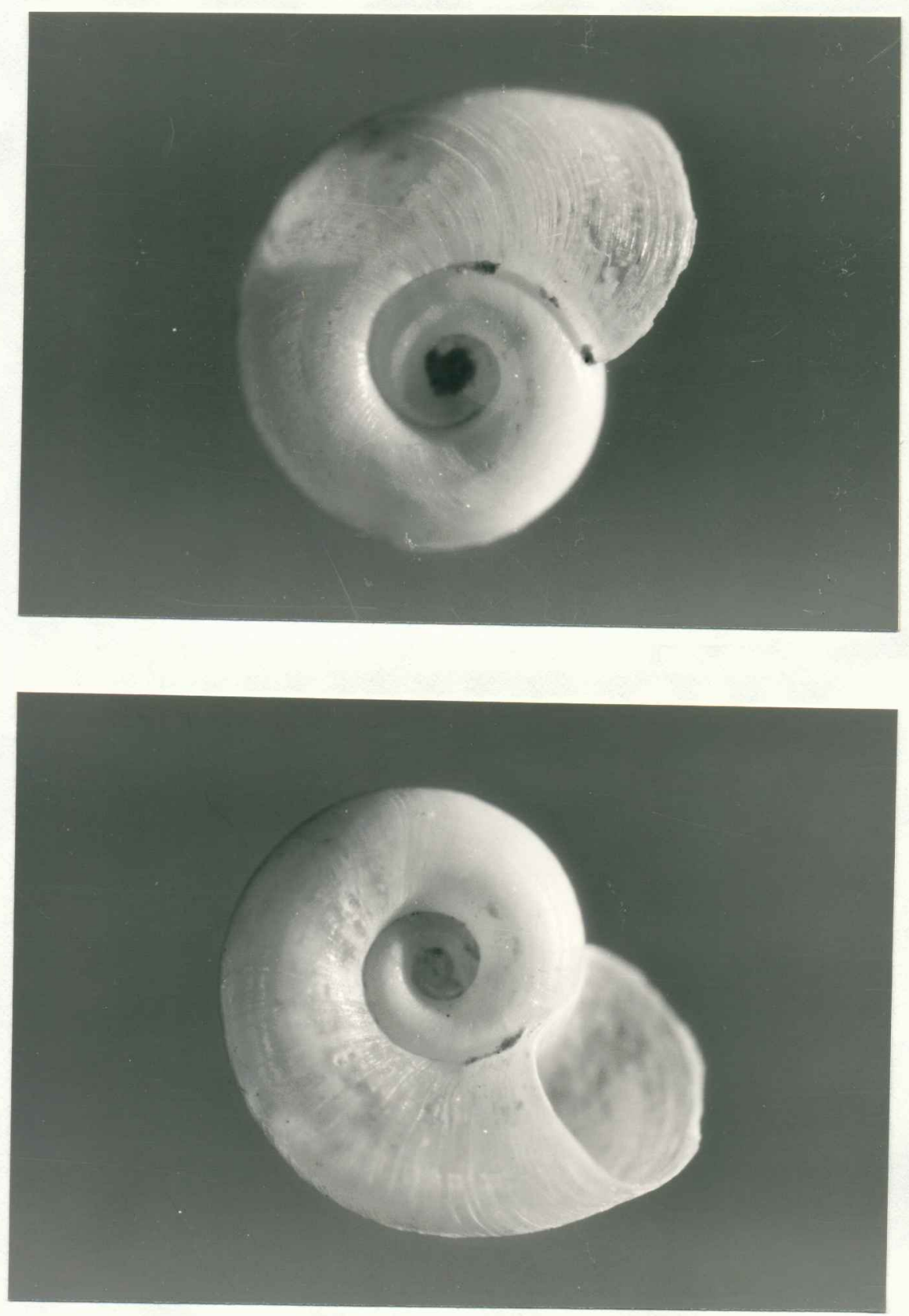

Approx $3 \mathrm{~mm}$

Figure 54. Gyralus parvus, $\underline{\text { c } 22 X}$ 

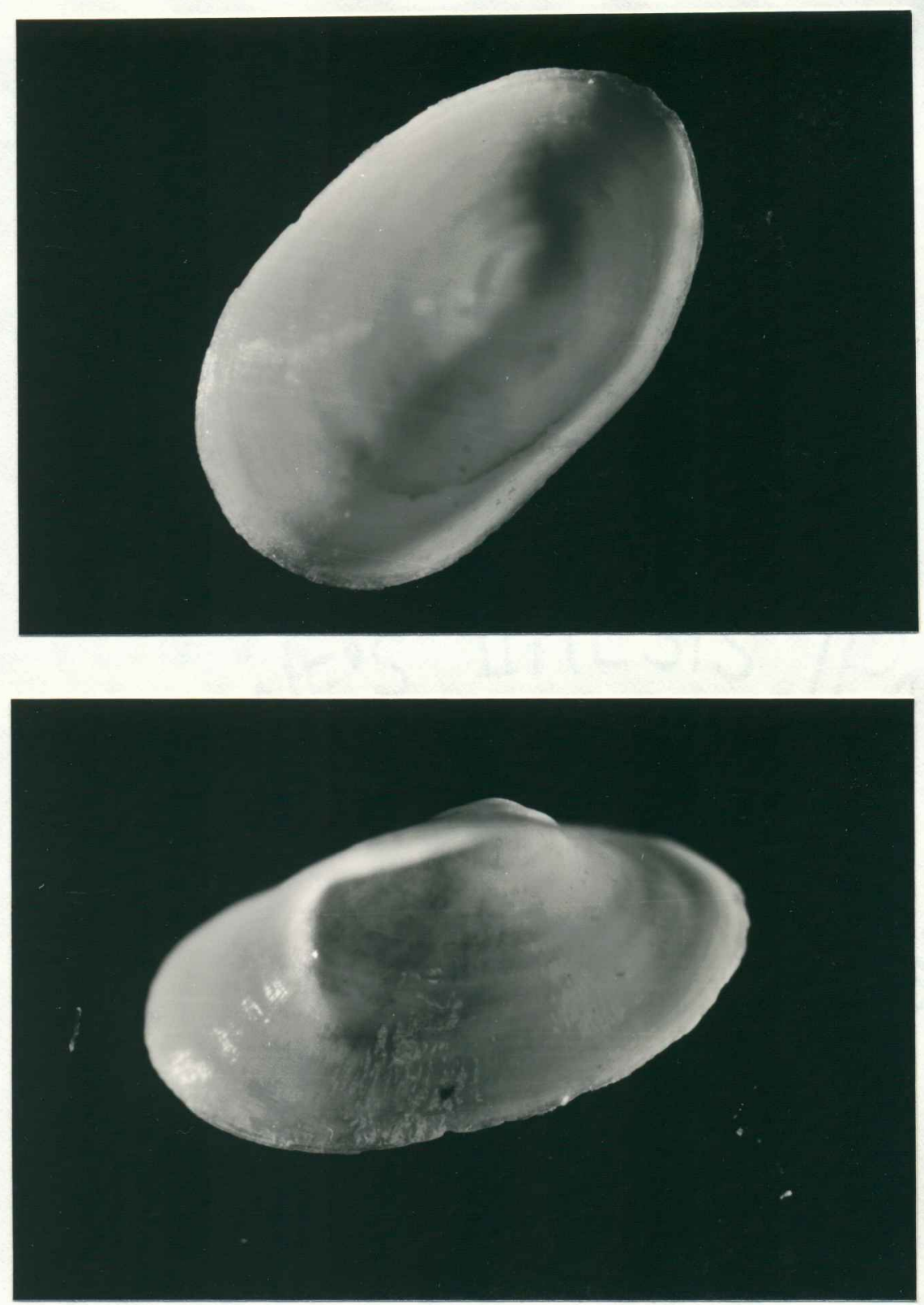

Approx $3 \mathrm{~mm}$

Figure 55. Ferrissia rivularis, c 23.6X 

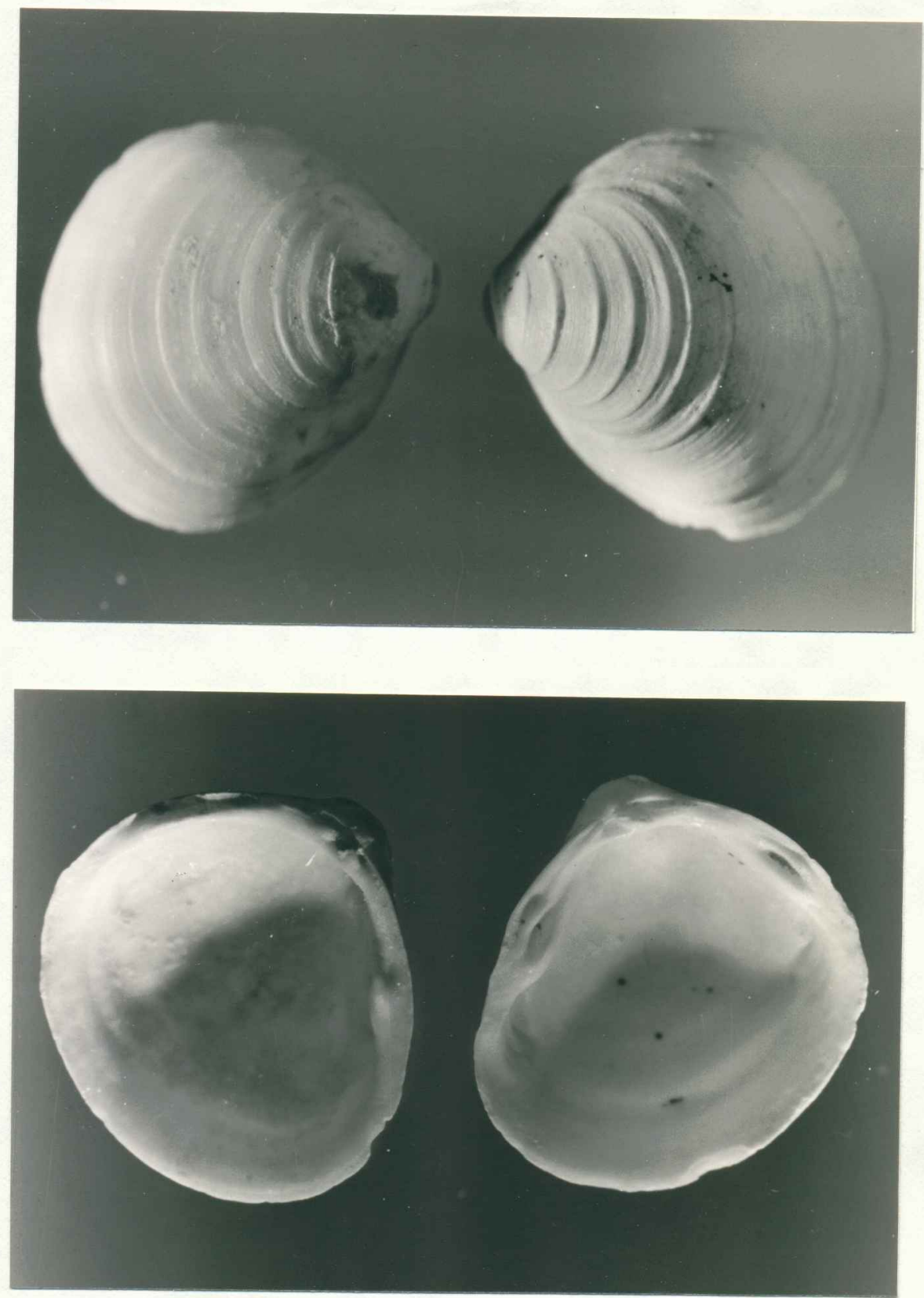

Approx. $5 \mathrm{~mm}$

Figure 56. Pisidium ultramontanum, c $10.6 \mathrm{X}$ Valves shown are from different individuals. 


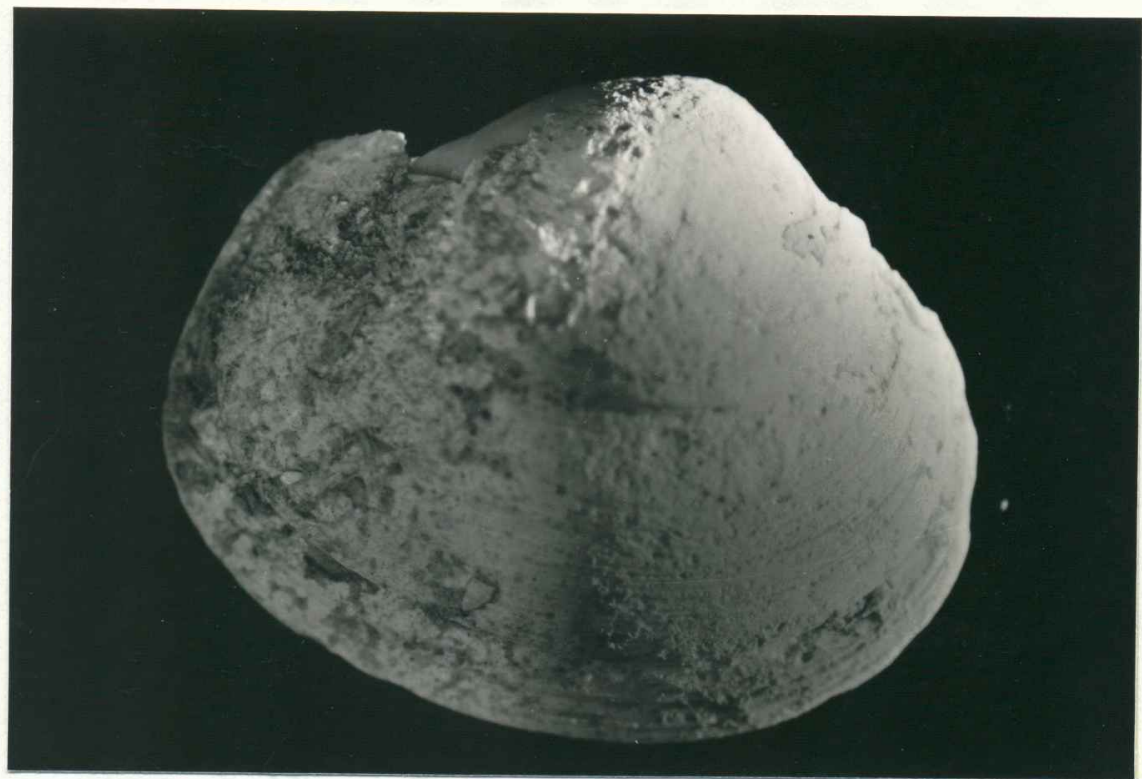

Approx $5 \mathrm{~mm}$

Figure 57. Sphaerium striatinum, c 9.7X. Portion of hinge edge missing on left side. 
recording and interpretation would have been much easier and probably far more accurate and detailed. One specific example can be mentioned. In the two test excavations, occasional individuals of $\underline{F}$. hendersoni were found throughout the soil column. At the time, this continued to suggest a lacustrine deposit in contradiction to the clasts that indicated flood plain alluvium. Good hindsight now tells me that the conditions there were wrong for $F$. hendersoni. It is obvious that the shells were transported with the suspended alluvium. Distribution of the $F$. hendersoni beds is limited and could have been determined by augering. I could thus have had a clue to the source of the alluvium and perhaps to the location of the stream channel.

In summary, if nonfood molluscan remains are present in a site, they can be key indicators of past environment and/or depositional history. 


\section{SUMMARY AND CONCLUSIONS}

Oregon's Harney Basin was closed more than 32,000 years ago by a series of fluid basaltic lava flows which poured from a source to the south into Malheur Gap and then moved several kilometers down the ancestral South Fork of the Malheur River. The result was a lava dam across the outlet of a catchment basin of almost $14,000 \mathrm{~km}^{2}$. After this damming, the interior of the Basin held a huge T-shaped lake which at its maximum extent could have been $80 \mathrm{~km}$ east to west and $92 \mathrm{~km}$ north to south.

The lava flow may actually have occurred much earlier in the Pleistocene than 32,000 B.P. By that time almost $90 \mathrm{~m}$ of alluvium had accumulated in the interior of the Basin and the lake floor was almost at the elevation of the sterile playas we see today. The lake itself, while still huge, had shrunk to a fraction of its original size due to siltation.

Four stillstands of Pluvial Lake Malheur have left beach line records, revealed in the walls of a long drainage ditch. All but the youngest of these are now dated. The oldest shoreline structure is underlaid by two earlier lake floors for which no equivalent beach lines were found. ${ }^{14} \mathrm{C}$ dates are being run on molluscs from deposits on these early lake floors, although results are not yet available. Elevations of the visible crests of the shoreline features and the dates associated with them are as follows: 


\section{TABLE VIII}

ELEVATIONS AND DATES OF PLUVIAL LAKE MALHEUR SHORELINES

$1243 \mathrm{~m} \quad(4078 \mathrm{ft})$ Present Harney Lake playa.

$1249.6 \mathrm{~m}$ (4099.7 ft) Youngest beach ridge series--undated.

$1251.1 \mathrm{~m}(4104.6 \mathrm{ft}$ ) Beach ridge dated 32,040 \pm 400 B.P. (USGS-459B)

$1252.2 \mathrm{~m}(4108.3 \mathrm{ft}$ ) Beach ridge dated $9620 \pm 50$ B.P. (USGS-460B)

$1253.3 \mathrm{~m}(4111.9 \mathrm{ft})$ Beach ridge presumed correlative with 8680 B.P. terrace

$1253.9 \mathrm{~m}(4114.0 \mathrm{ft})$ Spillway of Harney Basin.

$1255.1 \mathrm{~m}(4117.7 \mathrm{ft}$ ) Wave-cut terrace dated $8680 \pm 55$ B.P. (USGS-461B) 
The lake behind the 32,000 B.P. beach structure became completely silted in to the top of its associated beach ridge, possibly during a higher stillstand for which no shoreline evidence was found. This siltation may have occurred during the last pluvial episode, presumed to be correlative with the last stade of the Wisconsinan glaciation from about 25,000 to 12,000 B.P. There is nothing else in the stratigraphic record which appears to account for this time period.

At sometime prior to 9600 B.P. the lacustrine silt of the 32,000 B.P. lake was exposed and subaerially eroded. Thin veneers of flood-borne gravels mark this emergent episode. Then a lake rise occurred. A long bed of fossil snails associated with a buried shoreline and beach ridges mark this stage, dated to 9620 B.P. This stillstand appears correlative with a high lake level in the Abert Basin, $130 \mathrm{~km}$ to the southwest, dated at 9390 B.P.

A deposit of silt was laid in behind the 9620 B.P. beach structures. This served as a buttress to protect them from destruction by another lake rise a millenium later. The highest shoreline features observed in the Bas in were formed by a lake stillstand dated at 8680 B.P. This lake left a series of extensive beach ridges along the south shore of Harney Lake. It also cut prominent terraces in buttes and hillsides at several locations. At this time the lake was above the present level of the outlet in Malheur Gap and can be presumed to have been a part of the Columbia River drainage system.

The lakes of 32,000 B.P. and 9700 B.P., as well as those that existed during the last pluvial episode, probably also had Columbia River connections, although I have no evidence to support this. Malheur Gap 
lies in a graben in a tectonically active area. It is easy to conceive of a $3 \mathrm{~m}$ rise in elevation of the outlet between 32,000 and 8700 B.P. This would have allowed all of the lakes seen in the geologic record, except the youngest, to have overflowed and been a part of the Columbia River system. It is virtually unthinkable that the lake occupying the Basin during the full pluvial time was not at overflow level.

The youngest beach ridges are undated. They may be associated with the generally drier climate that occurred about 7000 years ago or they may have been formed by a considerably younger lake.

Because Pluvial Lake Malheur has not been contained within a closed basin for much of its history, I do not think it fruitful to make arbitrary side-by-side comparisons with other lake basins whose chronology is better known. The data from the Lahontan or Bonneville Basins should not be blindly imposed on the Harney Basin. The settings are not geologically or hydrologically comparable except perhaps during the last 7000 years.

Archaeological sites examined in the present study seem, with one exception, to be associated with the lake at or shortly after its maximum height about 8700 B.P. These are all lake margin sites. The largest is on what would have been a long narrow peninsula extending into a shallow littoral zone. It was strategically located to take advantage of such shallow water resources as fish, waterfowl, small aquatic fauna and edible aquatic plants.

The few diagnostic artifacts found are early types. These include crescents, basally ground small leaf-shaped points, points morphologically similar to Lind Coulee types, and a few artifacts that are apparently true blades. 
Pluvial Lake Malheur contained large salmonids which could have been very large native trout or salmon. These fish may have persisted well after the Columbia River connection was severed by falling lake levels. This was a major and generally unrecognized food resource, both in the Harney Basin and in other basins. It may be one of the reasons why sites prior to 7000 B.P. are so closely tied to lake margins and major streams. In some areas of the Great Basin these fish, rather than the dwindling Pleistocene megafauna, could have been the major targets of the early "Big Game Hunters."

By considering elevations and landforms, it may be possible to put some of the surface sites in the Basin into general age classes. As an example, sites at elevations slightly above $1254 \mathrm{~m}$ (4114 ft), that occupy a lakeside bench or similar lake-associated geomorphic feature, or are located near the mouth of an ephemeral stream, can be hypothesized to be about 8000-9000 years old. Obviously, care must be used in such associations and all of the evidence must be taken into account.

A single artifact was found in situ beneath a beach structure correlative with the 8680 B.P. lake. This is the earliest artifact from the Harney Bas in for which a reasonably reliable date exists. It proves that man was there before the final rise of Pluvial Lake Malheur to the highest level preserved in the geologic record. 


\section{BIBLIOGRAPHY}

Allen, D. C. and E. P. Cheatum

1960 Ecological implications of fresh-water and land gastropods in Texas archeological studies. Bulletin of the Texas Archeological Society 31:291-316.

Antevs, Ernst

1948 The Great Basin, with emphasis on Glacial and Postglacial times: climatic changes and pre-white man. Bulletin of the University of Utah 38(20):168-191.

1955 Geologic - climatic dating in the West. American Antiquity 20(4, pt. 1):317-335.

Atherton, John $\mathrm{H}$.

1966 Prehistoric manufacturing sites at North American stone quarries. Unpublished M.A. thesis, Department of Anthropology, University of Oregon.

Baker, Frank Collins

1942 Mollusca contained in the test pit deposits. In Archaeological researches in the northern Great Basin, L. S. Cressman. Carnegie Institute of Washington Publication 538:117-119. Washington.

Baldwin, Ewart M.

1964 Geology of Oregon. University of Oregon Cooperative Book Store, Eugene.

Baumhoff, Martin A. and Robert F. Heizer

1965 Postglacial climate and archaeology in the desert West. In The Quaternary of the United States, H. E. Wright, Jr. and David G. Frey (eds.), pp. 697-707. Princeton University Press, Princeton.

Bedwell, Stephen F.

1969 Prehistory and environment in the pluvial Fort Rock Lake area of southcentral Oregon. Ph.D. Dissertation, University of Oregon. University Microfilms, Ann Arbor.

1973 Fort Rock Basin: prehistory and environment. University of Oregon Books, Eugene.

Bedwe II, Stephen F. and Luther S. Cressman

1971 Fort Rock report: prehistory and environment of the pluvial Fort Rock Lake area of southcentral Oregon. In Great Basin Anthropological Conference, University of Oregon, 1970, Selected Papers, C. Melvin Aikens (ed.). University of Oregon Anthropological Papers 1:1-25. 
Beetle, Dorothy E.

1961 A checklist of recent. Wyoming mollusca. Sterkiana 3:1-9.

Benson, Char lotte L.

1979 Prehistoric marsh adaptation in the northwestern Great Basin: test excavations at 35HA403, MaTheur National Wild if ife Refuge. Paper presented at 32nd Annual Northwest Anthropological Conference, Eugene.

B lank, H. R., Jr. and Mark E. Gettings

1973 Geophysical evidence of caldera structure in the Harney Basin of central eastern Oregon. Paper presented at Fall Meeting, American Geophysical Union, San Francisco. Abstract in EOS $55: 557(1974)$.

Bowman, Isaiah

1935 Our expanding and contracting "desert." Geographical Review $65(5): 175-188$.

Broecker, Wallace S., Maurice Ewing, and Bruce C. Heezen

1960 Evidence for an abrupt change in climate close to 11,000 years ago. American Journal of Science 258:429-448.

Broecker, Wallace S. and Aaron Kaufman

1965 Radiocarbon chronology of Lake Lahontan and Lake Bonneville II, Great Basin. Geological Society of America Bulletin $76: 537-566$.

Broecker, Wallace S. and Phil C. Orr

1958 Radjocarbon chronology of Lake Lahontan and Lake Bonneville. Geological Society of America Bullet in 69:1009- 1032.

Call, R. E.

1884 On the Quaternary and Recent Mollusca of the Great Basin. U.S. Geological Survey Bulletin 11. Washington.

Campbe 11, Sarah

1980 Salvage archaeology at Site 35HA403, Malheur National Wildlife Refuge Headquarters: 1979. Unpublished manuscript on file, Superintendant, Malheur National Wildlife Refuge, Oregon.

Casteel, Richard W.

1976 Fish remains in archaeology and paleoenvironmental studies. Academic Press, London.

Clewlow, C. W., Jr.

1967 Time and space relations of some Great Basin projectile point types. University of Cal ifornia Archaeological Survey Reports 70:141-149. Department of Anthropology, Berkeley.

1968 Projectile points from Lovelock Cave, Nevada. University of Cal ifornia Archaeological Survey Reports 71:89-101. Department of Anthropology, Berkeley. 
Cressman, Luther S.

1942 Archaeological researches in the northern Great Basin. Carnegie Institute of Washington Publication 538. Washington.

1977 Prehistory of the far West. University of Utah Press, Salt Lake City.

Daugherty, Richard D.

1956 Archaeology of the Lind Coulee Site. American Philosophical Society, Proceedings 100(3). Philadelphia.

Driver, Harold E.

1969 Indians of North America, 2nd Ed., Revised. University of Chicago Press, Chicago.

Duebbert, Harold F.

1969 The ecology of Malheur Lake and management implications. U.S. Department of the Interior, Fish and Wildlife Service, Refuge Leaflet No. 412. Washington.

Dumond, D. E.

1962 Blades and cores in Oregon. American Antiquity 27:419-424.

Enbysk, Betty Joyce

1956 Vertebrates and Mollusca from Lind Coulee, Washington. In Archaeology of the Lind Coulee Site, Richard D. Daugherty (author). American Philosophical Society Proceedings $100(3): 267-278$.

Fagan, John Lee

1974 Altithermal occupation of spring sites in the northern Great Basin. University of Oregon Anthropological Papers 6, Eugene.

Ferguson, Denzel and Nancy Ferguson

1978 Oregon's Great Basin country. Gail Graphics, Burns.

Forbes, Char les Frank

1973 Pleistocene shoreline morphology of the Fort Rock Basin, Oregon. Unpublished Ph.D. dissertation, Department of Geography, University of Oregon.

Fritts, Harold C.

1965 Tree ring evidence for climatic changes in western North America. Monthly Weather Review 93:421-443.

1971 Dendroclimatology and dendroecology. Quaternary Research $1: 419-449$.

Gilbert, B. Miles

1973 Mammalian osteo-archaeology: North America. The Missouri Archaeological Society, Columbus. 
Gilbert, Grove Karl

1890 Lake Bonneville. Monographs of the U.S. Geological Survey 1. Washington.

Gladfelter, Bruce G.

1977 Geoarchaeology: the geomorphologist and archaeology. American Antiquity 42:519-538.

Grayson, Donald K.

1979 Mt. Mazama, climatic change, and Fort Rock Basin archaeofaunas. In Volcanism and human habitation, P. D. Sheets and D. K. Grayson (eds.), pp. 427-458. Academic Press, New York.

Greene, Robert C.

1970 A crystal rich ash-flow tuff in southeast Oregon. Paper presented at 66 th Annual Meeting, Cordilleran Section, Geological Society of America, Hayward, California. See also Geological Society of America Abstracts 2(2):97-98 (1970).

Greene, R. C., G. R. Walker, and R. E. Corcoran

1972 Geologic map of the Burns quadrangle, Oregon. U.S. Geological Survey, Map No. I-680. Washington.

Gruhn, Ruth

1965 Two early radiocarbon dates from the lower levels of Wilson Butte Cave, southcentral Idaho. Tebiwa 8(2):57. Idaho State University Museum, Pocatello.

Harding, Sidney T.

1942 Lakes. In Hydrology, Oscar E. Meinzer (ed.). Dover Publications, New York.

Hardman, George and Cruz Venstrom

1941 A 100-year record of Truckee River runoff estimated from changes in levels and volumes of Pyramid and Winnemucca Lakes. Transactions of the American Geophysical Union 22:71-90.

Hart, J. L.

1973 Pacific fishes of Canada. Fisheries Research Board of Canada, Ottawa.

Heizer, Robert F. and Thomas R. Hester

1978 Great Basin. In Chronologies in New World archaeology, R. E. Taylor and Clement W. Meighan (eds.), pp. 147-199. Academic Press, New York.

Hubbs, Carl L. and Robert R. Miller

1948 The Great Basin, with emphasis on Glacial and Postglacial times: the zoological evidence. Bullet in of the University of Utah 38(20):17-166. 
Hunt, Charles B.

1972 Geology of soils: their evolution, classification and uses.

W. H. Freeman, San Francisco.

Jennings, Jesse $D$.

1964 The desert West. In Prehistoric Man in the New Wor ld, Jesse D. Jennings and Edward Norbeck (eds.), pp. 149-174. University of Chicago Press, Chicago.

1974 Prehistory of North America. 2nd Edition. McGraw-Hill, New York.

Jennings, Jesse $D$. and Edward Norbeck

1955 Great Basin prehistory: a review. American Antiquity $21: 1-11$.

Jessup, L. T.

1939 Precipitation and tree growth in the Harney Basin. In Geology and groundwater resources of the Harney Basin, Oregon, A. M. Piper, T. W. Robinson, and C. F. Park, Jr. (authors), pp. 10-13. U.S. Geological Survey Water-Supply Paper 841 . Washington.

Johnson, Douglas W.

1965 Shore processes and shoreline development (facsimilie of 1919 edition). Hafner Publishing Co., New York.

Keen, F. P.

1937 Climatic cycles in eastern Oregon as indicated by tree rings. Month1y Weather Review 65(5):175-188.

Kroeber, Theodora

1961 Ishi in two worlds: a biography of the last wild Indian in North America. University of California Press, Berkeley.

Krumbein, W. C. and L. L. Sloss

1963 Stratigraphy and sedimentation, 2nd Ed. W. H. Freeman and Co., San Francisco.

LaMarche, Valmore C., Jr.

1974 Paleoclimatic inferences from long tree-ring records.

Science 183:1043-1048.

Longwe Il, Chester R. and Richard F. Flint

1962 Introduction to physical geology. John Wiley and Sons, New York.

Madsen, David B. and Michael S. Berry

1975 A reassessment of northeastern Great Basin prehistory. American Antiquity 40:391-405. 
Mehringer, Peter J., Jr.

1977 Great Basin late Quaternary environments and chronology. In Models and Great Basin prehistory, Don D. Fowler (ed.), pp. 113-167. Desert Research Institute Publications in the Social Sciences, Reno and Las Vegas.

Morrison, Roger B.

1961 Lake Lahontan stratigraphy and history in the Carson Desert

(Fallon) area, Nevada. U.S. Geological Survey Professional Paper 424-D:111-114. Washington.

1964 Lake Lahontan: Geology of southern Carson Desert, Nevada. U.S. Geological Survey Professional Paper 401. Washington.

1965 Quaternary geology of the Great Basin. In The Quaternary of the United States, H. E. Wright, Jr. and David G. Frey (eds.), pp. 265-285. Princeton University Press, Princeton.

Niem, Alan R.

1972 Wright's Point: an example of inverted topography. Paper presented at 68th Annual Meeting, Cordilleran Section, Geological Society of America, Honolulu. See also Geological Society of America Abstracts 4(3):209.

NOAA At las 2

1973 Precipitation frequency atlas of the western United States. Volume $X$ - Oregon. National Weather Service, Silver Spring, Md.

O'Connell, James F.

1967 Elko eared/ETko corner-notched projectile points as time markers in the Great Basin. University of California Archaeological Survey Reports 70:129-140.

Oregon

1967 Malheur Lake basin. State Water Resources Board, Salem, Oregon.

Parker, Donald James

1974 Petrology of selected volcanic rocks of the Harney Basin, Oregon. Unpublished Ph.D. dissertation, Oregon State University, Corvallis.

Parker, Donald and Richard Lee Armstrong

$1972 \mathrm{~K}-\mathrm{Ar}$ dates and $\mathrm{Sr}$ isotope initial ratios for volcanic rocks in the Harney Basin, Oregon. I sochron/West 5:7-12.

Pettigrew, Richard M.

1975 Cultural resources survey in the Alvord Basin southeastern Oregon. University of Oregon, Department of Anthropology, Eugene. 
Piper, A. M., T. W. Robinson, and C. F. Park, Jr.

1939 Geology and grourd-water resources of the Harney Basin, Oregon. U.S. Geological Survey Water-Supply Paper 841 . Washington.

Roscoe, Ernest J.

1961 Preliminary check list of Lake Bonneville mollusca.

Sterkiana 4:23-28.

Ruhe, Robert V.

1975 Geomorphology: geomorphic processes and surficial geology. Houghiton Mifflin, Boston.

Russe 11, Israel C.

1884 A geological reconnaisance in southern Oregon. U.S. Geological Survey 4th Annual Report, pp. 431-464. Washington.

1903 a Preliminary report on artesian basins in southwestern Idaho and southeastern Oregon. U.S. Geological Survey Water-Supply Paper 78. Washington.

1903b Geology of southwestern Idaho and southeastern Oregon. U.S. Geological Survey Bulletin 217. Washington.

1905 Preliminary report on the geology and ground water resources of central Oregon. U.S. Geological Survey Bulletin 252. Washington.

Sears, Paul B. and Aino Roosma

1961 A climatic sequence from two Nevada caves. American Journal of Science 259:669-678.

Shinn, Dean A.

1977 Man and the land: an ecological history of fire and grazing on eastern Oregon rangelands. Unpublished M.S. thesis, Oregon State University, Corvaltis.

Snyder, John 0 .

1908 Relationships of the fish fauna of the lakes of southeastern Oregon. Bulletin, U.S. Bureau of Fisheries 27:69-102.

Snyder, C. T., George Hardman, and F. F. Zdenek

1964 Pleistocene lakes in the Great Basin. U.S. Geological Survey, Map No. I-416. Washington.

Snyder, Char les T. and Walter B. Langbe in

1962 The Pleistocene lake in Spring Valley, Nevada, and its climatic implications. Journal of Geophysical Research $67: 2385-2394$. 
Steward, Julian $H$.

1938 Basin-Plateau aboriginal sociopolitical groups. Bureau of American Enthnology Bulletin 120. Washington.

Taylor, Dwight W.

1960 Report on referred fossils. In Cultural sequences at The Dalles, Oregon: a contribution to Pacific Northwest prehistory, L. S. Cressman (author). Transactions of the American Philosophical Society, new series, 50:Part 10 .

n.d. Freshwater molluscs from Malheur National Wildlife Refuge, Harney County, Oregon. Manuscript on file, Superintendant, Malheur National Wildlife Refuge, Oregon.

Walker, George W. and Donald A. Swanson

1967 Summary report on the geology and mineral resources of the Harney Lake and Malheur Lake areas of the Malheur National Wildlife Refuge, north-central Harney County, Oregon. U.S. Geological Survey Bulletin 1260-L:1-17. Washington.

Waring, Gerald A.

1909 Geology and water resources of the Harney Basin, Oregon. U.S. Geological Survey Water-Supply Paper 231. Washington.

Weide, Margaret

1974 North Warner subsistence network: a prehistoric band territory. Nevada Archaeological Survey Research Paper 5:62-82.

Williams, J. Stewart, Allen D. Willard, and Verlyn Parker

1962 Recent history of Bear Lake Valley, Utah-Idaho. American Journal of Science 260:24-36.

U.S. Geological Survey Topographic Maps: Oregon Series

1967 Adobe Flat, 7 1/2'

1972 Circle Bar, 7 1/2'

1960 Crane, 15'

1967 Coyote Butte, $712^{\prime}$

1959 Dog Mountain, 15'

1967 Irish Lake, 7 1/2'

1967 Jackass Butte, $71 / 2^{\prime}$

1971 Keg Springs Valley East, 7 1/2'

1971 Keg Springs Valley West, 7 1/2'

1959 Lawen, 15'

1977 Sand Gap, $71 / 2^{\prime}$

1968 Wildhorse Lake, 7 1/2'

Preprints:

n.d. Harney Lake 3NE, 4NE, 4NW, 4SE, and 4SW, 7 1/2'

Vertical Aerial Photographs

1972 Harney Lake, Oregon. Series GS-SWGM, Scale 1:20,571.

Photograph Nos. 1-41 through 1-46 and 1-57 through 1-61,

U.S. Geological Survey, Menlo Park, California. 


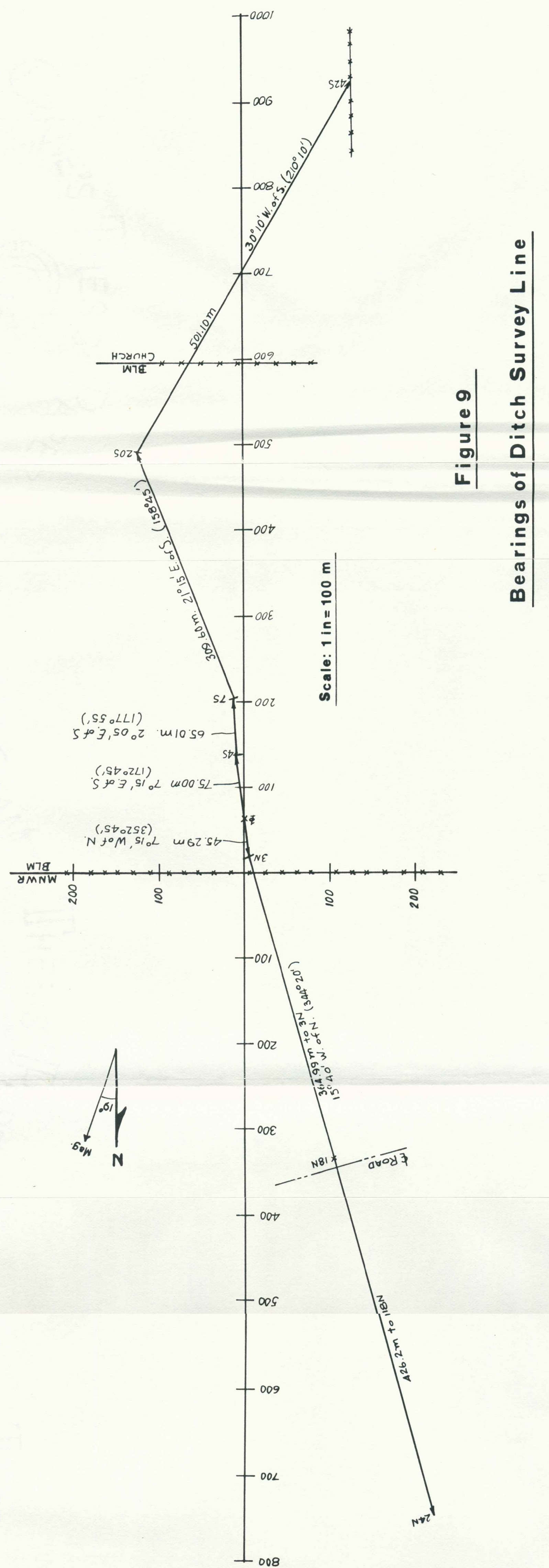




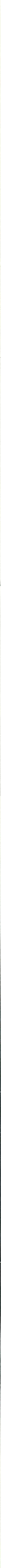





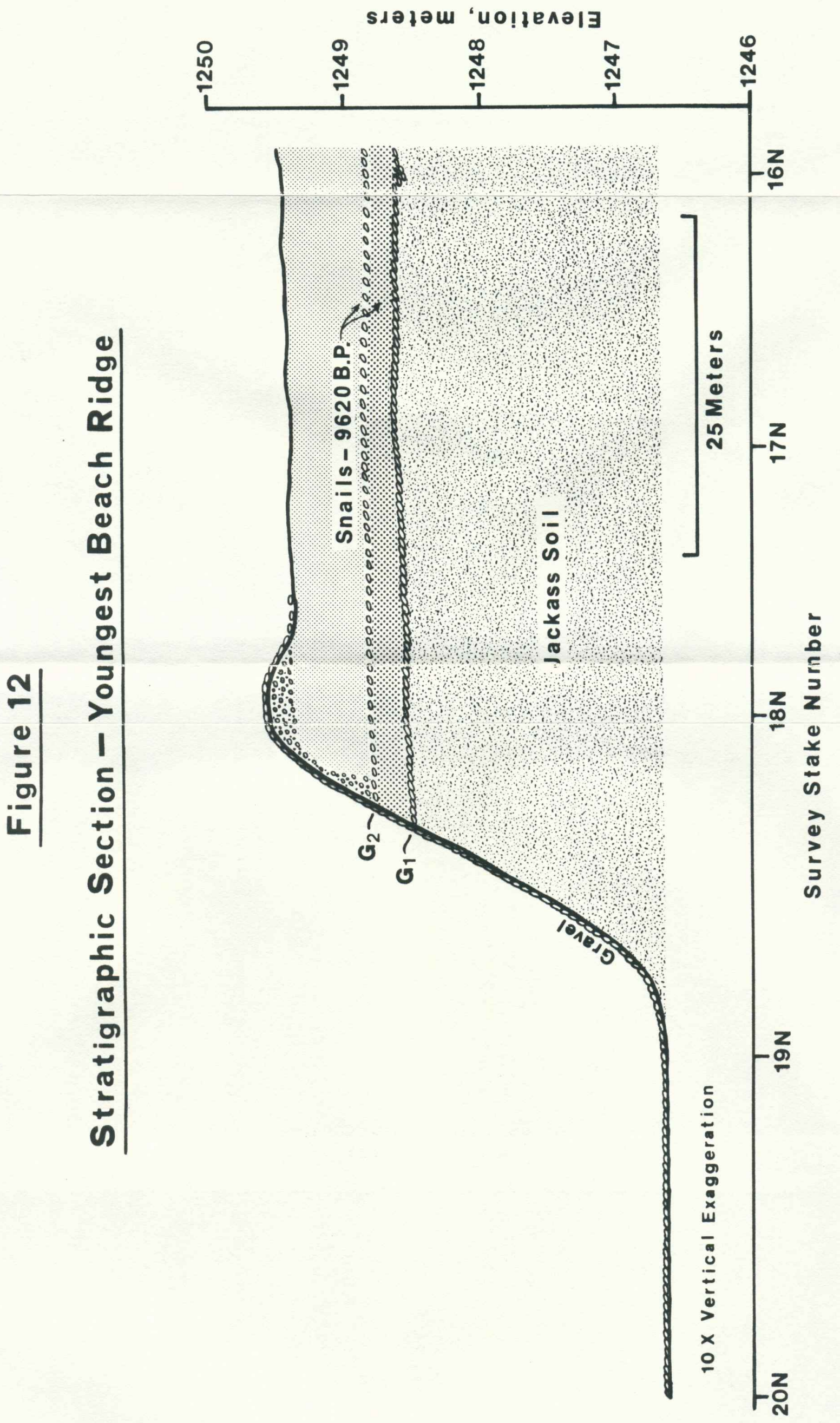




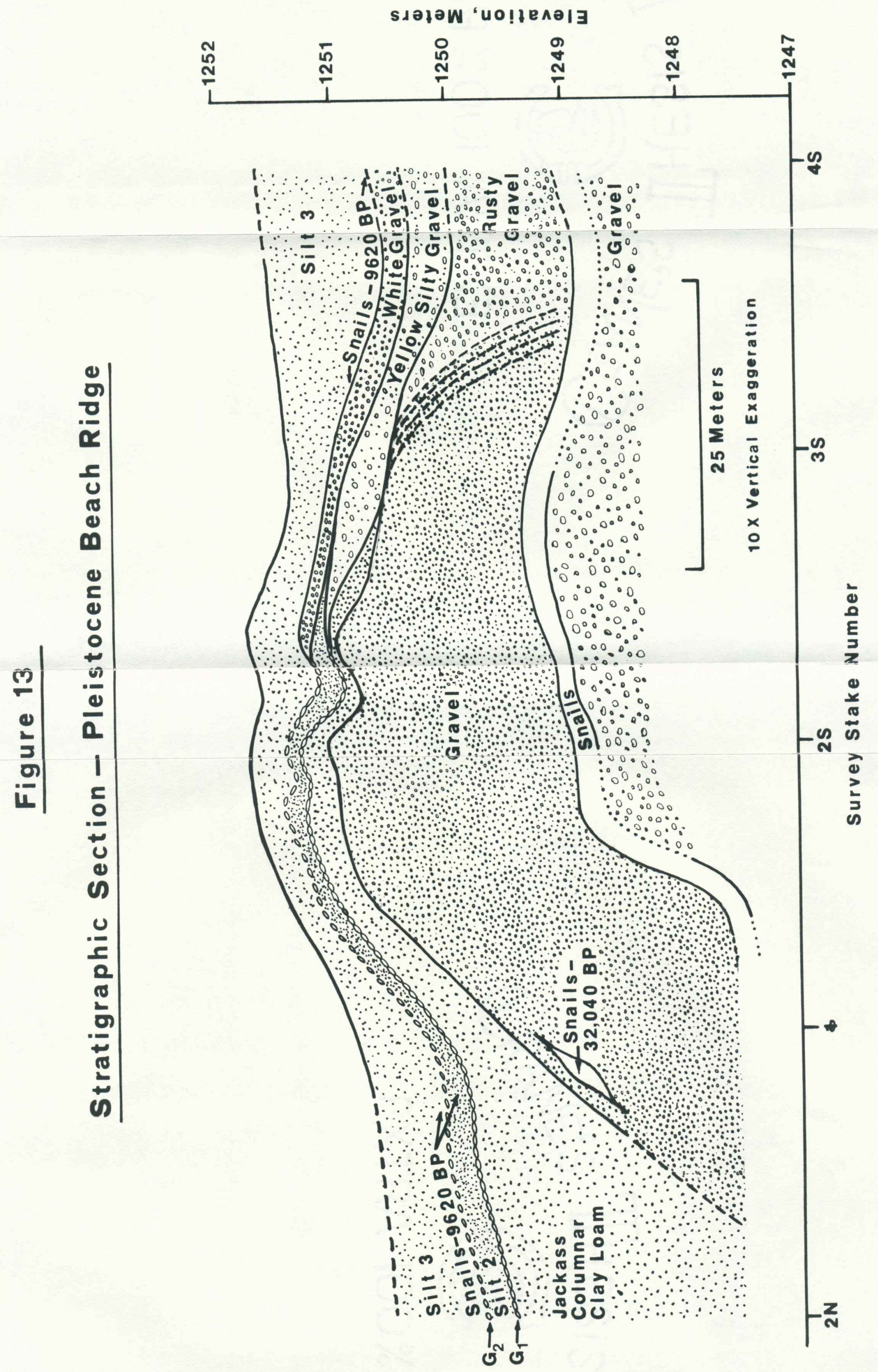




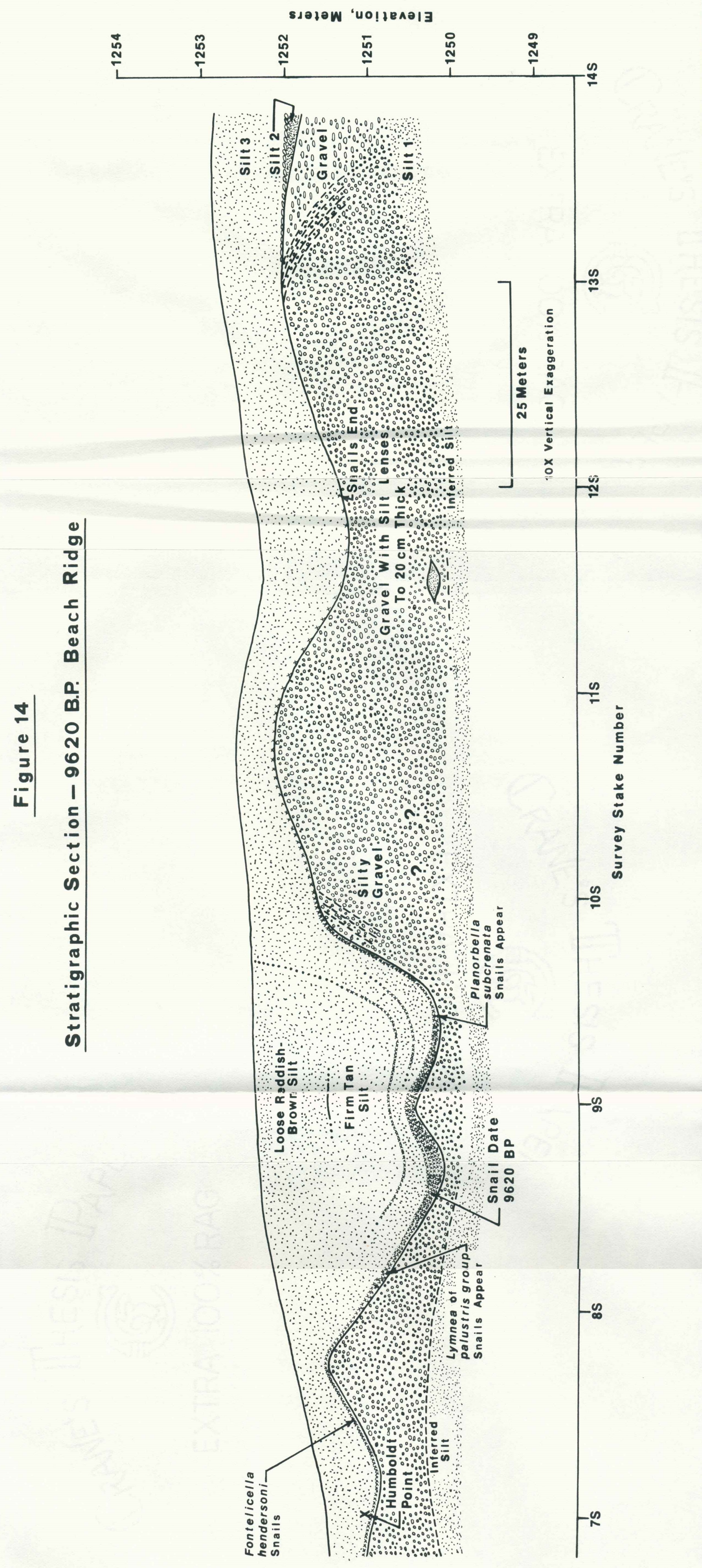



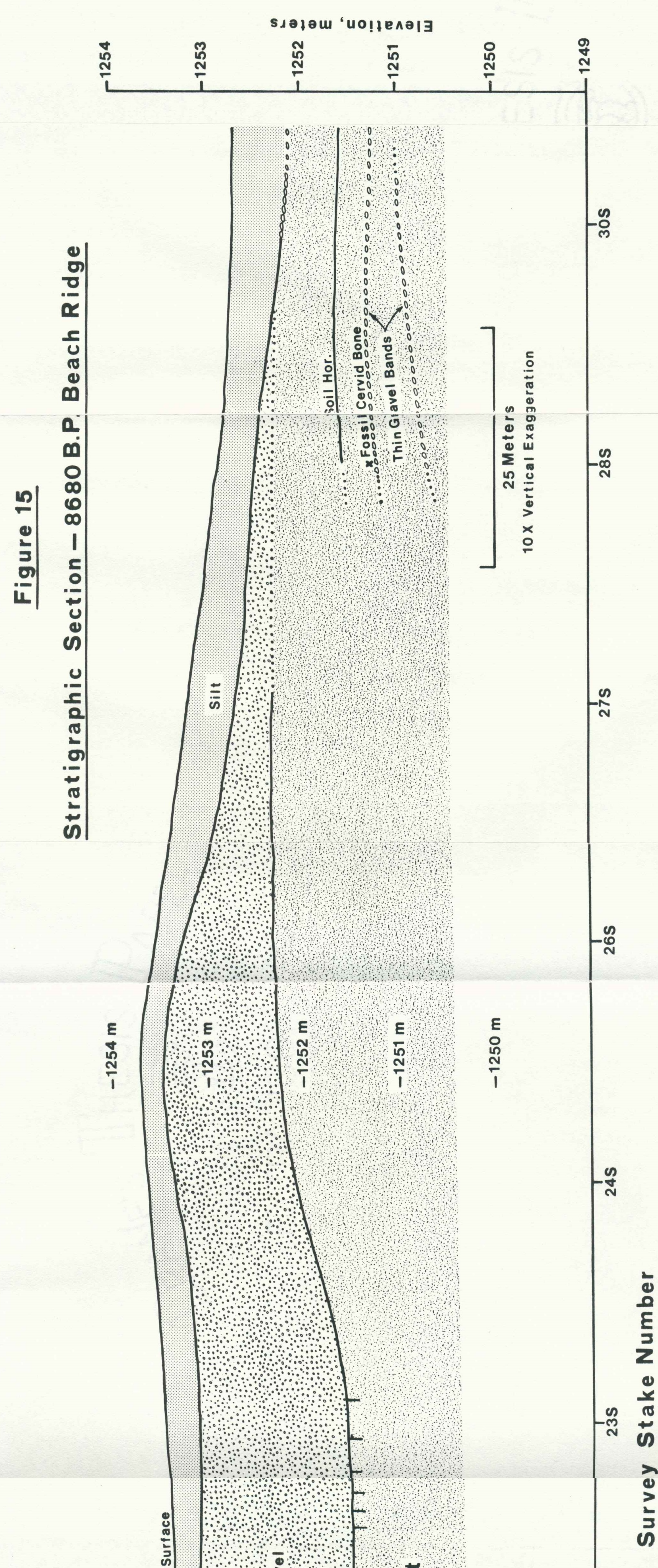

:प:? :

或

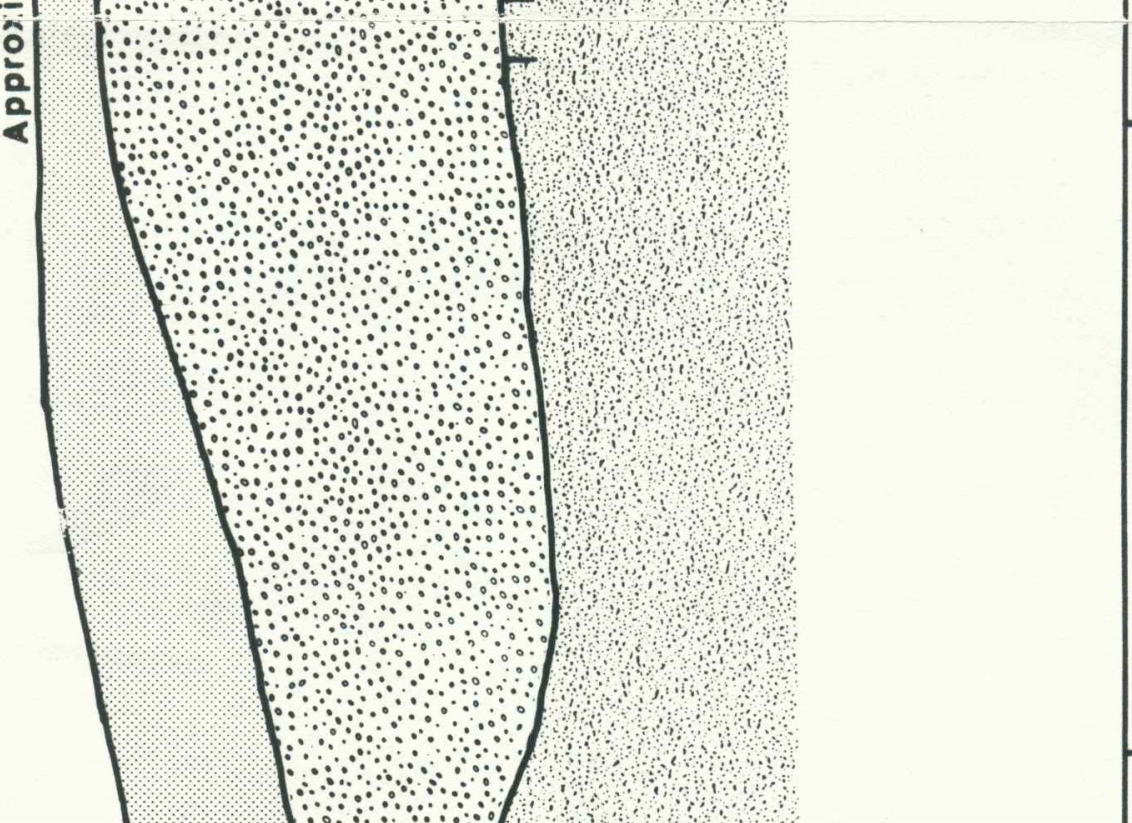

$\overline{\bar{\omega}}+4$ a
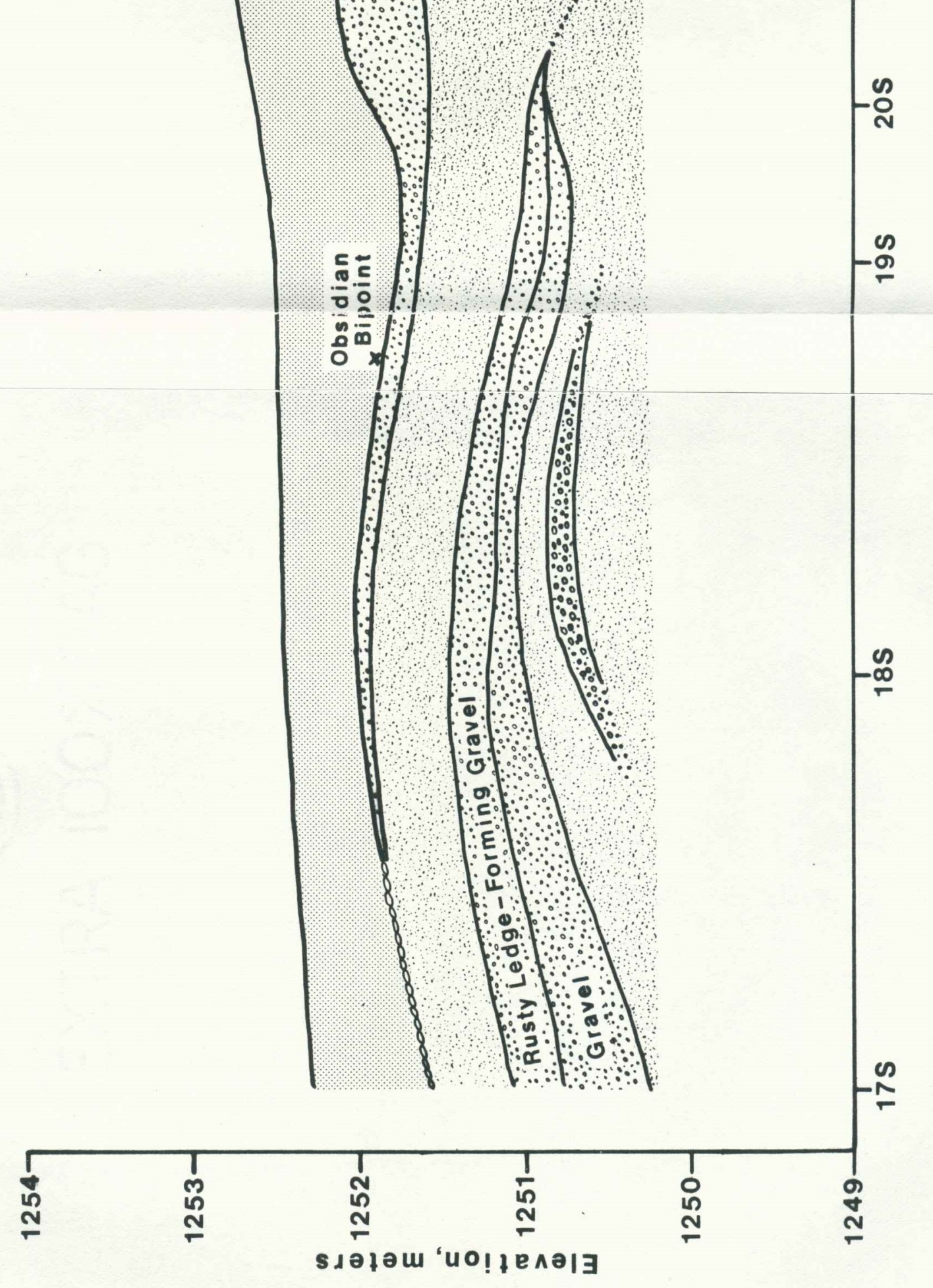


\section{APPENDIX}

\section{LOCATION AND ELEVATION OF SURVEY MARKS}

All surveying at the site was relative to a U.S. Geological Survey benchmark identified as 118 MDC 1973 4121. This is located on the wave-

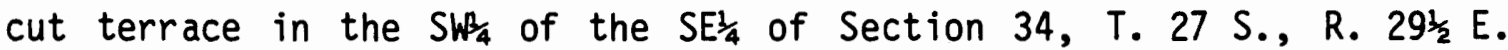
(Harney Lake 4NE, Oregon n.d.) The geodetic control list of the U.S. Geological Survey lists the location as follows:

Burns Post Office, $25.9 \mathrm{mi} \mathrm{S}$. of, along State Highways 78 and 205 , thence $11.1 \mathrm{mi} \mathrm{SW}$. and $\mathrm{W}$. along a track $\mathrm{rd}$. [the south Harney Lake road]; at a $Y-r d$. SW.; $328 \mathrm{ft} \mathrm{S.} \mathrm{of} \mathrm{the} \mathrm{centerline} \mathrm{of} \mathrm{the}$ rd., $56 \mathrm{ft} \mathrm{SE}$. of the centerline of the $r d$. SW., $9 \mathrm{ft} \mathrm{NW}$. of a cairn, about $4 \mathrm{ft}$ higher than the $\mathrm{rd}$. bed; cemented in a lava boulder that projects $3 \mathrm{ft}$ and sets on the north side of the northwest corner of a rock faced cliff; a standard tablet stamped "118 MDC 1973 4121."

The field book elevation of this benchmark is 4120.846 feet $(1256.04 \mathrm{~m})$.

A transit line was shot from the benchmark at a true bearing of $235^{\circ} 00^{\prime}$ until it intersected the fenceline of the Malheur National Wildlife Refuge, a stadia distance of $452.5 \mathrm{~m}$. The point of intersection was approximately $10 \mathrm{~m}$ east of the ditch and exactly $2.00 \mathrm{~m}$ east of the first steel fence post east of the ditch. A steel axle was driven in with the head flush with the ground. This point was designated the "working datum." Its elevation is $1251.34 \mathrm{~m}(4105.46 \mathrm{ft})$ above sea level.

The working datum is $114.38 \mathrm{~m}$ west of a bronze $\frac{1}{4}$ section monument set in a concrete post and identified by a yellow fence post. This is marked T. 27 S. R. $29 \frac{1}{2}$ E. Sect $34 \frac{1}{4} 1967$.

All true bearings were reckoned on the presumption that the Refuge fenceline was due east-west. At this point it runs along both section and 
township lines. Compass bearings using $19 \frac{1}{2}^{\circ}$ east declination confirm this assumption.

A permanent site datum was set on top of a low gravel hillock $196.0 \mathrm{~m}$ (stadia distance) due south of the working datum. This is a length of $\frac{3}{2}$ inch steel reinforcing bar projecting about $20 \mathrm{~cm}$ out of the ground. Elevation of the top of this stake was $1252.61 \mathrm{~m}(4109.61 \mathrm{ft})$.

Excavation squares were identified by the coordinates of the corner of the $2 \times 2 \mathrm{~m}$ unit which was closest to the site datum.

\section{RADIOCARBON DATING}

Dr. Stephen W. Robinson, U.S. Geological Survey, Menlo Park, California, generously agreed to date shell samples from the Harney Lake study area. Four samples were sent in March, 1978 and two additional samples in October, 1979.

There was possible contamination of the shell by younger carbonates since caliche deposits were prevalent in the sediments in which they were located. Sampling locations were chosen to minimize this problem, where possible

When the samples were calcined, the first portion of $\mathrm{CO}_{2}$ was collected and counted separately. This $\mathrm{CO}_{2}$ was presumed to be from the surface portion of the shell most likely to have been contaminated by younger carbonate. The difference in dates between surface and inner portions of the shell is a rough measure of this contamination. One of the original samples was accidentally treated conventionally during calcining. This date is thus an average of younger and older carbonates. As might be expected, the date appears anomously low. Dr. Robinson has 
advised me that the inner fraction dates should be the more nearly accurate and I have used them throughout this report.

Sample information and ${ }^{14} \mathrm{C}$ dates are as follows:

Sample 35HA342-6

USGS-459A 22,900+260 B.P. (outer fraction)

USGS-459B $32,040 \pm 400$ B.P. (inner fraction)

This was a sample of mollusc shells taken adjacent to survey stake $\emptyset$ from a lens in the east wall of the ditch, on the lakeside face of a gravel beach ridge (Figures 10 and 13 ). The predominant snail species was Vorticifex effusus.

Sample 35HA342-7

USGS-458 23,800 \pm 500 B.P. (composite)

The sample was from a thin $(5 \mathrm{~cm})$, isolated lens of mollusc shell in the under surface of the rusty-appearing gravel band near the base of the west wall of the ditch at location 5S (Figure 10). Again the predominant species was Vorticifex effusus. The sample was taken before the 1979 flood which scoured out the ditch bottom at this point to reveal two additional snail bands. The stratigraphy at this location is not clear. I believe the isolated lens to be a continuation of the upper of these newly exposed snail colonies. If this is the case, the sample must be earlier in age than the beach ridge from which Sample 35HA342-6 was taken. Sample 35HA342-62, not yet reported, will provide a check on this date.

Sample 35HA342-8

USGS $-460 \mathrm{~A} \quad 9280+80$ B.P. (outer fraction)

USGS-460B $9620+50$ B.P. (inner fraction) 
This sample was from a dense, thick (ㄷ $12-15 \mathrm{~cm})$ fossil snail deposit at the base of the west bank of the ditch, about $10 \mathrm{~m}$ north of location 9S (Figures 10 and 14 ). The predominant species is Fontelicella hendersoni. The sampling location is a broad trench in the beach ridge series between stakes $10 \mathrm{~S}$ and 13S. This snail band is prominent in the ditch walls for about 700 meters, where it clearly marks a lake floor environment.

Sample 35HA342-9 (MNWR-143-21)

USGS-461A 8060+50 B.P. (outer fraction)

USGS-461B 8680+55 B.P. (inner fraction)

This sample was taken from a wave-cut terrace about $70 \mathrm{~m}$ due south of USGS benchmark 118 MDC along the side of a butte facing into the northeast entrance of Jackass Bay. The sample comprised fossil snails, predominantly of the species Fontelicella hendersoni. At the location sampled, the snails occurred in a moderately dense deposit about 5-10 cm beneath the soil surface.

Samp le 35HA342-62

USGS-

USGS-

This is a sample of gastropod shells from an exposure in a washout in the middle of the ditch floor at approximate location 5S. This snail bed underlies the beach ridge between stakes $\emptyset$ and $3 S$ which has been dated to 32,000 B.P. The predominant snail species is Vorticifex effusus. Helisoma newberryi was also plentiful. 
Sample 35HA342-63

USGS-

USGS-

This sample represents the oldest lakefloor discovered among those revealed in the ditch. It was a gastropod sample taken from bedded snails at the base of the west wall of the ditch about $10 \mathrm{~m}$ south of location $5 \mathrm{~S}$. These snail beds were overlaid by about $15 \mathrm{~cm}$ of sterile gravel which, in turn, was overlaid by the snail bed comprising sample 35HA342-62. The major species present was Fontelicella hendersoni. 


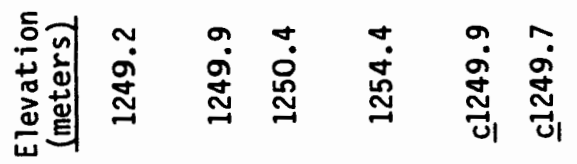

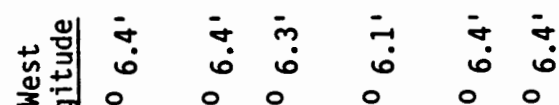

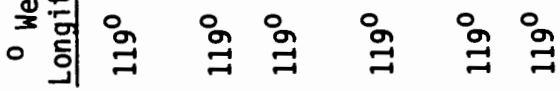

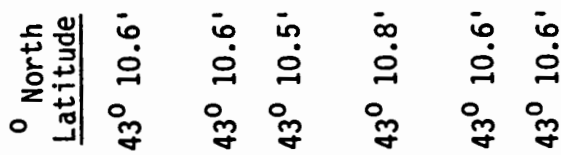

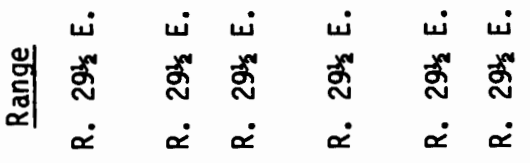

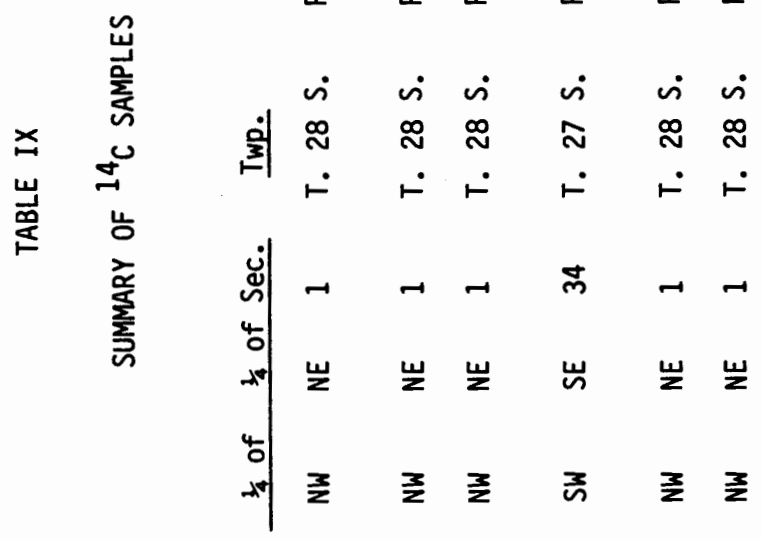

$$
\begin{aligned}
& \text { 융워 은 }
\end{aligned}
$$

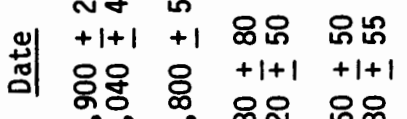

$$
\begin{aligned}
& \text { స̃ }
\end{aligned}
$$

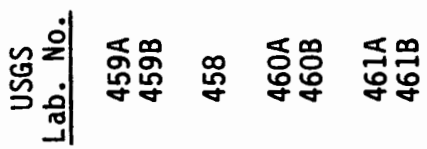

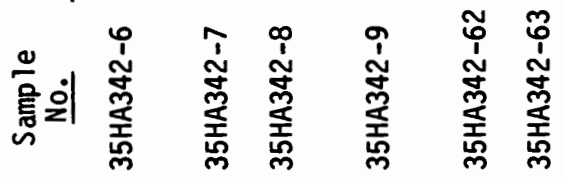

